DOE/RL-96-73

Revision 0

UC-630, 721

\title{
The 324 Building Radiochemical Engineering Cells and High-Level Vault Closure Plan
}

Date Published
May 1997

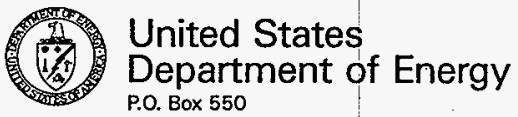

Richland, Washington 99352

Approved for Public Release 
TRADEMARK OISCLAIMER

Reference herein to any specific commercial product, process, or service by trade name, trademark, manufacturer, or otherwise, does not necesserily constitute or imply its endorsement, recommendation, or favoring by the United States Government or any agency thereof or its contractors or subcontractors.

This report has been reproduced from the best available copy. Available in paper copy and microfiche.

Available to the U.S. Department of Energy and its contractors from

U.S. Department of Energy

Office of Scientific and Technical Information (OSTI)

P.O. Box 62

Oak Ridge. TN 37831

(615) 576-8401

Available to the public from the U.S. Department of Commerce Nationsl Technical Information Service (NTIS)

5285 Port Royal Road

Springfield, VA 22161

(703) $487-4650$

Printed in the Unitad States of America

DISCLM-5.CHP (8-95) 
1. COMPLETE THIS SECTION FOR ALL DOCUMENTS

B. Document ID Number (include rev., vol., etc.)

DOE/RL-96-73, Revision 0

C. List attachments (i.e., copyright permission, copyright transfer)

D. Document Title

The 324 Building Radiochemical Engineering Cells and High-Level Vault Closure Plan

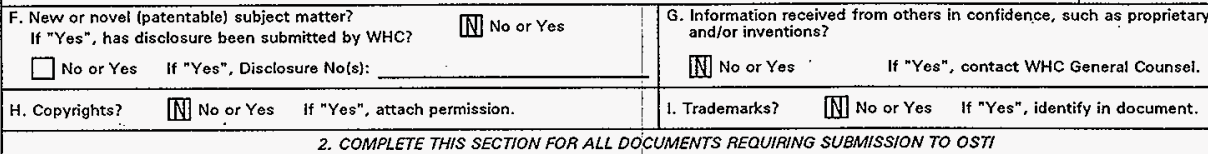

\begin{tabular}{|ll|ll}
\hline A. Unclassified Category & UC $-630, U C-2000$ & B. Budget \& Reporting Code & B\&R - EX3120020 \\
\hline 3. COMPLETE THIS SECTION ONLY FOR A JOURNAL SUBMISSION \\
\hline
\end{tabular}

A. Title of Journal

4. COMPLETE THIS SECTION ONLY FOR A SPEECH OR PRESENTATION

\begin{tabular}{|c|c|c|c|}
\hline \multicolumn{2}{|c|}{ A. Title for Conference or Meeting } & \multicolumn{2}{|l|}{ B. Group or Society Sponsoring } \\
\hline $\begin{array}{l}\text { C. Date(s) of Conference } \\
\text { or Meeting }\end{array}$ & D. City/State & $\begin{array}{l}\text { E. Will material be published in proceedings? } \\
\text { Will material be handed out? }\end{array}$ & $\begin{array}{l}\text { No or Yes } \\
\text { No or Yes }\end{array}$ \\
\hline
\end{tabular}

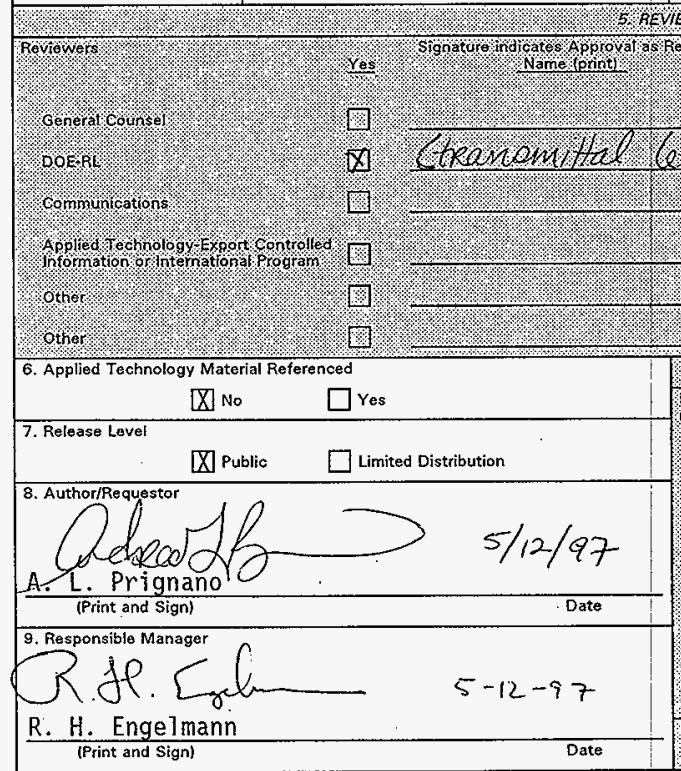

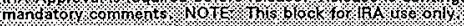

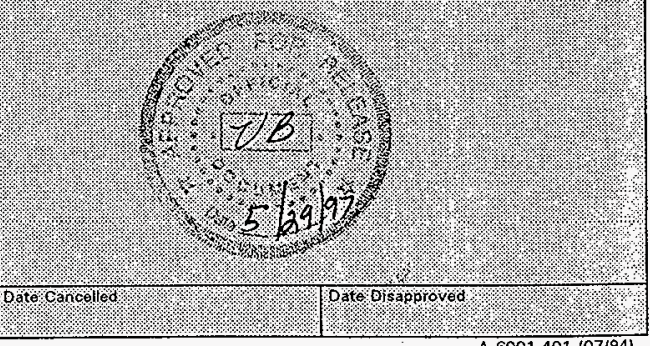




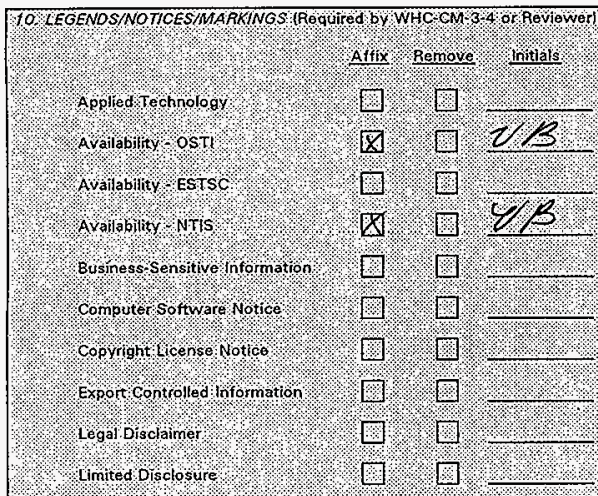

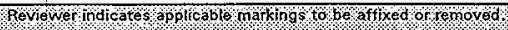

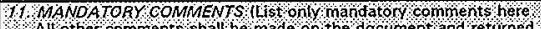 Al other comments shall be made on the documont and zeturned to the authion}

officiluse onty

patents status

predectsional hatomation

Programinationotico

froprietany arformation.

Porososond Use

Tresisioissetation

Tradonark Disclaimer

othert
Affix Remove 1 Initials

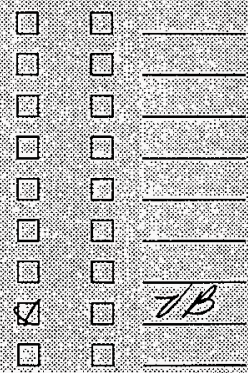

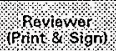

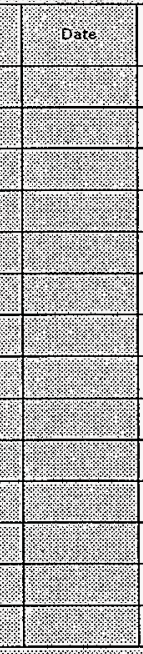

Resolved by Author/Requestor (Print \& Sign) 


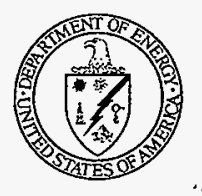

97-EAP-447

$\mathrm{Mr}$. Steve Alexander

Perimeter Section

Nuclear Waste Program

State of Washington

Department of Ecology

1315 West Fourth Avenue

Kennewick, Washington 99336

Dear Mr. Alexander:

TRANSMITTAL OF DOE/RL-96-73, 324 BUILDING RADIOCHEMICAL ENGINEERING CELLS AND HIGH-LEVEL VAULT CLOSURE PLAN. REVISION 0

The DOE/RL-96-73, 324 Building Radiochemical Engineering Cells and High-Level Vault Closure Plan, Revision 0, and the State Environmental Policy Act Checklist are submitted for your review.

This closure plan incorporates the requirements and decisions made during a Data Quality Objectives process held in 1996 by State of Washington Department of Ecology, U.S. Department of Energy. Richland Operations Office, and contractors associated with closure of the 324 Building.

If there are any questions, please contact E. M. Mattlin of my staff on (509) $376-2385$.

EAP:EMM

Sincerely.

Enclosure

Cc w/encl:

EDMC. H6-08

W. Adair, FDH

M. Jaraysi, Ecólogy

R. Jim, YIN

D. Powaukee, NPT

J. Wallace, Ecology

J. Wilkinson. CTUIR
Cc W/o encl:

R. Bowman, RFSH

S. Price, FDH

F. Ruck, FDH 


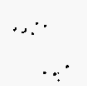

STATE ENVIRONMENTAL POLICY ACT ENVIRONHENTAL CHECKLIST

\section{FOR}

HANFORD FACILITY,

THE 324 BUILDING RADIOCHEMICAL ENGINEERING CELLS

AND HIGH-LEVEL VAULT CLOSURE PLAN

MAY 1997

WASHINGTON ADMINISTRATIVE CODE

ENVIRONMENTAL CHECKLIST FORMS

[WAC $197-11-960]$ 
1. Name of project, if applicable:

Closure of the 324 Building Radiochemical Engineering Cells (REC) and High-Level Vault (HLV), 300 Area; Hanford Site.

2. Name of appiicants:

U.S. Department of Energy, Richland Operations Office (DOE-RL).

3. Address and phone number of applicants and contact persons:

U.S. Department of Energy

Richland Operations Office

P.0. Box 550

Richland, Washington 99352.

Contact Persons:

J. E. Rasmussen, Division Director

Office of Environmental Assurance, (509) 376-5541:

4. Date checklist prepared:

. May 1997

5. Agency requesting the checklist:

Washington State Department of Ecology

Kennewick Office

1315 West 4 th Avenue

Kennewick, Washington 99336

6. Proposed timing or schedule: (including phasing, if applicable):

This SEPA Environmental Checklist is being submitted to support closure of units within the 324 Building. A schedule for closure activities is proposed as part of the closure plan with activities completed during 2002.

7. Do you have any $p$ lans for future additions, expansions, or further activity related to or connected with this proposal? If yes, explain.

No. There are no plans to expand or increase the capacity of the building or to add structures. 
8. List any environmental information you know about that has been prepared, or will be prepared, directly related to this project.

This SEPA Environmental Checklist is being submitted to the State of Hashington Department of Ecology (Ecology) with the 324 Building REC and HLV Closure Plan, which was prepared in accordance with the Washington State Dangerous Haste Regulations.

The following documents have been prepared in accordance with DOE National Environmental Policy Act regulations:

Categorical Exclusion for Removal of Material from the Hot Cells and Vaults, 324 Building, Hanford Site, Richland, WA (PNNL Project Number 13802) (dated September 15, 1995).

Memorandum to File: Cleanout and Decontamination of Five Hot Cells in the 324 and 325 Buildings at Hanford in Compliance with the National Environmental Policy Act (dated October 10, 1990).

General information concerning the Hanford Facility environment can be found in the Hanford Site National Environmental Policy Act (NEPA) Characterization, PNL-6415, Revision 8, August 1996. This document is updated periodically by Pacific Northwest National Laboratory (PNNL), and provides current information concerning climate and meteorology; ecology; history and archeology; socioeconomic; land use and noise levels; and geology and hydrology. These basel ine data for the Hanford Site and. its past activities are useful for evaluating proposed activities and their potential environmental impacts.

9. Do you know whether applications are pending for government approvals of other proposals directly affecting property covered by your. proposal?

No applications to government agencies are known to be pending. However, the 324 Building lies within Comprehensive Environmental Response, Compensation, and Liability Act (CERCLA) operable units (OU) 300-FF.-3 and $300-\mathrm{FF}-5$ as designated by the Hanford Federal Facility Agreement and consent order. These operable unit:s are scheduled to be remediated under CERCLA using the remedial investigation and feasibility study process.

10. List any government approvals or permits that will be needed for your project, if known.

Ecology is the lead agency authorized to approve the closure plan for the $324 \mathrm{REC} / \mathrm{HLV}$ pursuant to the requirements of the WAC 173-303 and 40 Code of Federal Regulations (CFR) Part 265.

Additional permits (e.g., stormwaten) applicable to all facilities on the Hanford Site have been prepared. 
SEPA Checklist

324 Building

Page 3 of 22

1 11. : Give a brief, complete description of the project, including the uses and

the size of the project and site. There are several questions later in this checklist that ask you to describe certain aspects of your project. You do not need to repeat those answers on this page.

The DOE-RL proposes clean closure of non-permitted treatment, storage, and/or disposal (TSD) units housed within the 324 Building. Two areas within the 324 Building were found to have stored dangerous waste for greater than the 90-day period allowed for non-permitted facilities. All of the areas of the 324 Building were considered in defining the boundary for closure. The areas of the building requiring closure activities include: the REC (B-Cell, portions of D-Cell, the airlock, and the pipe trench), the HLV, the LLV, the HLV sample room, the Engineering Development Lab (Room 146), and the gallerjes.

After the waste inventory has been removed, clean closure of the REC, the HLV and LLV, the piping, and the miscellaneous areas will be accomplished by decontaminating, as necessary, and demonstrating that these components meet the closure performance standard. For metal surfaces and concrete the closure performance standard is a 'clean debris surface', as defined in 40 CFR 268.45. Decontamination of the REC units will involve cleaning the interior surfaces. Decontamination of the HLV and LLV will include removal of the tanks and cleaning all metal and concrete surfaces to the performance standard of a 'clean debris surface'. Piping that has transported dangerous waste will be rinsed and the rinsate sampled, analyzed, designated, and disposed. Specified piping will be isolated. clean closure of the underlying soil will be completed by demonstrating that there are no through-thickness cracks in the building concrete that could have allowed. dangerous waste to penetrate to the soil. If it is not possible to demonstrate that the soil is clean, investigation into potential soil contamination will be coordinated and integrated with the CERCLA remedial action process for the OU.

Closure of the 324 Building REC/HLV will be performed in accordance with the Ecology-approved closure plan.

12. Location of the project. Give sufficient information for a person to understand the precise location of your project, jncluding a street address, if any, and section, township, and range, if known. If the project occurs over a range of area, provide the range or boundaries of the site(s). Provide a legal description, site plan, vicinity map, and topographic map, if reasonably available. While you should submit any plans required by the agency. you are not required to duplicate maps or detailed plans submitted with any permit applications related to this checkl ist.

The 324 Building is located near the corner of Locust Street and the George Washington Way Extension north of the city of Richland, in the 300 Area of the Hanford Site. 
B. ENVIRONMENTAL. ELEMENTS

1. Earth

a. General description of the site- Flat; rolling, hilly, steep slopes, mountainous, other.

The site is essentially flat.

b. What is the steepest slope on the site (approximate percent slope)?

Approximately 2 percent.

c. What general types of soils are found on the site? (for example, clay, sancly gravel, peat, muck)? If you know the classification of agricultural soils, specify them and note any prime farmland.

Soil types consist mainly of eclian and fluvial sands and gravel. More detailed information concerning specific: soil classifications can be found in the Hanford Site National Environmental Poilicy Act (NEPA) Characterization, PNL-64.15, Revision 8, August 1996. Farming is not. permitted on the Hanford Facility.

d. Are there surface indications or history of unstable soils in the immediate vicinity? If so, describe.

No.

e.' Describe the purpose, type, and approximate quantities of any filling or grading proposed. Indicate source of tillt.

No filling or grading is required.

f. Could erosion occur as a result: of clearing, construction, or use? If so, senerally describe.

No. 
g. About what percent of the site will be covered with impervious surfaces after project construction (for example, asphait or buildings)?

Not applicable. No construction would occur.

h. Proposed measures to reduce or control erosion, or other impacts to the earth, if any:

Not applicable. Earth would not be disturbed.

2. Air

a. What types of emissions to the air woutd. result from the proposal (i.e., dust, automobile, odors, industrial wood smoke) during construction and when the project is completed? If any, generally describe and give approximate quantities, if known.

Minor amounts of exhaust would be generated by vehicles used by personnel to gain access to the 324 Building.

An airborne release could occur as a result of upset conditions internaliy or externally. Such a release would not exceed immediately dangerous to life and health concentrations outside the immediate area of the spill/release because of the small quantity of material that is available for release.

b. Are there any off-site sources of emissions or odors that may affect your project? If so, generally describe.

No.

c. Measures to reduce or control emissions or other impacts to the air, if any?

Good engineering practices would be followed, and actions would comply with 
3. Water

\section{a. Surface}

1) Is there any surface water body in or in the immediate vicinity of the site (including year-round and seasonal streams, saltwater, lakes ponds, wet 1 ands)? If yes, describe type and provide names. If appropriate, state what stream or river it flows into.

The Columbia River is in the vicinity of the 324 Building. However, the 324 Building is a nonland-.based facility as defined in WAC $173-303-282$ (3) (i). The WAC 173-303-282(6)(c)(i)(Ei)(I) requires nonland-based facilities bie located at least 152 meters from any perennial water body. The. WAC 173-303-282(6)(d).(i) requires nonland-based facilities bie located at least 152 meters from any wetlands, designated critical habitats, habitats designated by the Washington Department of Wildlife as habitat essential to the maintenance or recovery of any state listed threatened or endarigered wildlife species, natural areas that are acquired or voluntarily registered or dedicated by the owner, or state or federally designated wildijife refuges, preserves, or bald eagle firotection areas. The 324 Building is over 152 meters from any of the:se areas. 
2) Will the project require any work over, in, or adjacent to (within 200 feet) the described waters? If yes, please describe and attach available plans.

No.

3) Estimate the amount of fill and dredge material that would be placed in or removed from surface water or wetlands and indicate the area of the site that would be affected. Indicate the source of fill material.

None.

4) Will the proposal require surface water withdrawals or diversions? Give general description, purpose, and approximate quantities if known.

No.

5) Does the proposal iie within a 100-year floodplain? If so, note location on the site plan.

No.

6) Does the proposal involve any discharges of waste materials to surface waters? If so, describe the type of waste and anticipated volume of discharge.

No.

b. Ground

1) Will ground water be withdrawn, or will water be discharged to ground water? Give general description, purpose, and approximate quantities if known.

If the REC and HLV cannot be clean closed in accordance with RCRA regulations, postclosure groundwater monitoring might be required. 
2) Describe waste materials that will be discharged into the ground from septic tanks or other sources, if any (for example: Domestic sewage: industrial, containing the following chemicals; agricultural; etc.). Describe the general size of the systen, the number of such systems, the number of houses to be served (if applicable), or the number of animals or humains the system(s) are expected to serve.

None.

c. Water Run-off (including storm water)

1) Describe the source of rur-off (including storm water) arid methods of collection and disposa1, if any (include quantities, if kriown). Where will this water flow? Will this water flow into other wastes? lf so, describe.

The Hanford Facility receives only 15.2 to 17.8 centimeters of annua? precipitation. Precipitation runs off the existing buildings and seeps into the soil on and near the buildings. This precipitation does not reach the groundwater or surface waters. Precipitation would not come in contact with any of the liquid misied waste treated and/or stored.

2) Could waste materials enter ground or surface waters? If so, generally describe.

Engineering controls durirg closure activities, such as inspecting the liners for breaches before: using decontamination solutions, etc., will prevent dangerous wastes from entering the groundwater. 
d. Proposed measures to reduce or control surface, ground, and run-off water impacts, if any:

Measures would include inspecting for breaches or cracks, and sealing any found, before using decontamination solutions.

\section{Plants}

a. Check the types of vegetation found onsite.

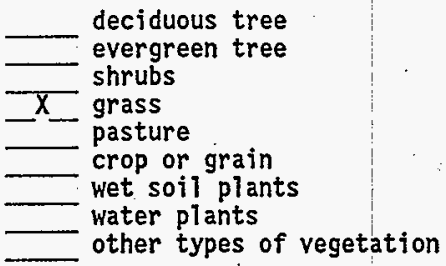

The most common vegetation community in the 300 Area is the sagebrush/cheatgrass or Sandberg's bluegrass. Natjue vegetation in the immediate vicinity of the 324 Building has been eradicated. Vegetation consists primarily of cultivated ornamentals.

b. What kind and amount of vegetation will be removed or altered?

None.

c. List threatened or endangered species known to be on or near the site.

None. Additional information on the Hanford Facility environment can be found in the environmental document referred to in the answer to Checkl ist Question A.8.

d. Proposed landscaping, use of native plants, or other measures to preserve or enhance vegetation on the site, if any:

Not applicable. 
5. Animals

a. Undertine any birds and animats which have been observed on or near the site or are known to be on or near the sita:

birds: hawk, heron, eagle, songbirds, other:

mammals: deer, bear, elk, beaver, other: .... Small mamnals

fish: bass, salmon, trout, herring, shellfish, other:

Raptors (burrowing owls; ferruglinous, redtail, and Swainson's hawks) rarely are seen in the 300 Area. Small pisserines (sparrows, finches) are present; in the general vicinity of the 324 Building. Mule deer, rabbits, and coyotes occisionally are

b. List any threatened or endangered species known to be on or near the sitel.

Two federal and state 1 isted threatened or endangered species have been icentified on the 1,450 square kilometer Hanford Site along the Columbia River; the bald eagle and peregrine falcon. In addition, the state listed white pelican, sandhill crane, and ferruginous hawk also occur on or migrate. through the Hanford Site. of these five species; none is likely to use the shrubsteppe habitat of the 300 Area.

c. Is the site part of a migration route? If so, explain.

The Hanford Facility is part of the broad Pacific flyway.

d. Proposed measures to preserve or enhance wildlife, if any:

None. 
6. Energy and Natural Resources

2

a. What kinds of energy (electric, natural gas, oil, wood stove, solar) will be used to meet the completed project's energy needs? Describe whether it will be used for heating, manufacturing, etc.

Electricity will be used for lighting and other cleanup operations.

b. Hould your project affect the potential use of solar energy by adjacent properties? If so, generally describe.

No.

c. What kinds of energy conservation features are included in the plans of this proposal? List other proposed measures to reduce or control energy impacts, if any:

None.

\section{Environmental Health}

a. Are there any environmental health hazards, including exposure to toxic chemicais, risk of fire and explosion, spill, or hazardous waste, that could occur as a result of this proposal? If so, describe.

Possible environmental health hazards to workers could arise from activities at the 324 Building. The hazard could come from exposure to radioactive, dangerous, and/or mixed waste. Stringent administrative controls and engineered barriers will be employed to minimize the probability of even a minor incident and/or accident. $A$ chemical spill, release, fire, or explosion could occur only as a result of a simultaneous breakdown in multiple barriers or a catastrophic natura] forces event. 
1) Describe special emergency services that might be required.

Hanford Facility security, fire response, and ambulance services are on call at all times in the event of an onsite emergency. Hanford Facility emergency services personilel are specially trained to manage a variety of circumstances involving chemical and/or mixed waste constituents and situations.

2) Proposed measures to reduce or control environmental health hazards, if any:

Al] personnel are trained to follow proper procedures during the treatment and storage operations to minimize potential exposure. The 324 Building has systems for ventilation, radiation monitoring, fire protection, and alarm capability. The heating, ventilation, and air conditioning system maintains a negative air pressure in the 324 Building.

Chemical and radiological safety hazards would be mitigated by preventing direct contact with the residual chemical constituents; highefficiency particulate ail filtration of all offgas streams; and protective clothing, appropriate training, and respiratory protection used. by onsite personnel as necessary.

b. Noise

1) What type of noise exists in the area which may affect your project (for example: traffic, equipment, operation, other)? None. 
What types and levels of noise would be created by or associated with the project on a short-term or a long-term. basis (for example: traffic, construction, operation, other)? Indicate what hours noise would come from the site.

None.

3) Proposed measures to reduce or control noise impacts, if any:

None.

8. Land and Shoreline Use

a. What is the current use of the site and adjacent properties?

The Hanford Facility is a single RCRA facility identified by the U.S. Environmental Protection Agency (EPA)/State Identification Number WA7890008967 that consists of over 60 TSD units conducting dangerous waste management activities. These TSD units are included in the Hanford Facility Dangerous Waste Part $A$ Permit Application. The Hanford Facility consists of all contiguous land, and structures, other appurtenances, and improvements on the land, used for recycling, reusing, reclaiming, transferring, storing, treating, or disposing of dangerous waste, which, for the purposes of the RCRA, are owned by the U.S. Government and operated by the DOE-RL, excluding land owned by Washington State.

b. Has the site been used for agriculture? If so, describe:

No portion of the Hanford Facility has been used for agricultural purposes since 1944 . 
c. Describe any structures on the site.

The 324 Building, located in the 300 Area, is a steel and reinforced concrete structure. Numerous buildings surround the 324 Building as a result of the developed 300. Area.

d. Will any structures be demolisined? If so, what?

No.

e. What is the current zoning

classification of the site?

The Hanford Site is zoned by Benton County as an Unclassified Use (U) district.

f. What is the current comprehensive plan designation of the site?

The 1985 Benton County Comprehensive Land Use Plan designates the Hanford Site as the "Hanford Reservation". Under this designation, land on the Hanford Site may be used for "activities nuclear in nature." Nonnuclear activities are authorized if and when DOE approval for such activities is obtained".

g. If applicable, what is the curient shoreline master program designation of the site?

Not applicable.

h. Has any part of the site been classified as an "environmentaliy sensitive" area? If so, specify.

No.

i. Approximately how many people would reside or work in the completed project?

None. 
j. Approximately how many people would the completed project displace?

None.

k. Proposed measures to avoid or reduce displacement impacts, if any: .

None.

1. Proposed measures to ensure the proposal is compatible with existing and projected land uses and plans, if any:

Not applicable. (Refer to Checklist Question B.8.f)

\section{Housing}

a. Approximately how many units would be provided, if any? Indicate whether high, middle, or low-income housing.

None.

b. - Approximately how many units, if any, would be eliminated? Indicate whether high, middie, or low-income housing.

None.

c: Proposed measures to reduce or control housing impacts, if any:

None.

10. Aesthetics

a. What is the tallest height of any proposed structure(s), not including antennas; what is the principal exterior building material(s) proposed?

No new structures are being proposed. The unit is located in an existing building, which is approximately 14 meters high. 
11. Light and Glare

b. What views in the immediate vicinity would be altered or obstructed?

None.

c. Proposed measures to reduce or control aesthetic impacts, if any:

None.

a. What type of light or glare will the proposal produce? What time of day would it mainly occur?

None.

b. Could light or glare from the finished project be a safety hazard or interfere with views?

No.:

c. What existing off-site sources of light or glare may affect your proposal?

None.

d. Proposed measures to reduce or control light and glare impacts, if any:

None.

12. Recreation

a. What designated and informal recreational opportunities are in the immedilate vicinity?

None.

b. Would the proposed project displace any existing recreational uses? If so, describe.

No. 
13. Historic and Culturai Preservation

c. Proposed measures to reduce or control impacts on recreation, including recreation opportunities to be provided by the project or applicant, if any?

None.

a. Are there any places or objects listed on, or proposed for, national, state, or local preservation registers known to be on or next to the site? If so, generally describe.

No places or objects listed on, or proposed for, national, state, or. local preservation registers are known to be on or next to the 324 Building.

b. Generally describe any landmarks or evidence of historic, archaeological, scientific, or cultural importance known to be on or next to the site.

There are no known archaeologica], historical, or Native American religious sites in the 324 Building area:

c. Proposed measures to reduce or control impacts, if any:

None.

14. Transportation

a. Identify public streets and highways serving the site, and describe proposed access to the existing street system. Show on site plans, if any.

Not applicable.

b. Is site currentiy served by pubiic transit? If not, what is the approximate distance to the nearest transit stop? 
No. The distance to the nearest public transit stop is approximately 113 meters located near the entrance to tive 300 Area.

c. How many parking spaces would the completed project have? How many would the project eliminate?

Not applicable.

d. Will the project require any new roads or streets, or improvements to existing roads or streets, not including driveways? If so, generally describe (indicate whether public or private).

No.

e. Will the project use (or occur in the immediate vicinity of) water, pail, or air transportation? If so, genera $1 y$ describe. No.

f. How many vehicular trips per day are generated by the completed project? If known, indicate when peak volunes occur.

No additional vehicular traffic: will be required.

g. Proposed measures to reduce or control transportation impacts, if any:

None.

15. Public Services

a. Would the project result in an increased need for public services (for example: fire protection, police protection, health care, schools, other)? If so, generally describe.

No. Existing services are adecuate. 
b. Proposed measures to reduce or controt.

direct impacts on public services, if any:

None.

16. Utilities

a. Circle utilities currently available at the site: electricity, natural gas, water, refuse service, telephone, sanitary sewer, septic system, other:

Electricity, telephone, sewer, water, and refuse collection are available at the 324 Building.

b. Describe the utilities that are proposed for the project, the utility providing the service, and the generai construction activities on the site or in the immediate vicinity which might be needed.

All utilities for the 324 Building are currently available. No new utility services would be required. 
SEPA Checklist

324 Building

Page 20 of 22

This page intentionally left blank. 
SEPA Checklist

324 Building

Page 21 of 22

\section{SIGNATURES}

3 The above answers are true and complete to the best of my knowledge. We 4 understand that the lead agency is relying on them to make its decision. office of Environmental Assurance, Permits, and Policy Division.

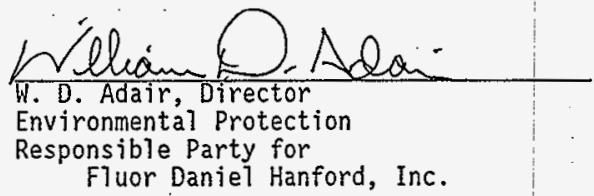

$$
14 \text { U.S. Department of Energy }
$$

W. D. Adair, Director Environmental Protection

Fluor Daniel Hanford, Inc. 
SEPA Checklist

324 Building

Page 22 of 22

This page intentiona.jly left blank. 


\section{THE 324 BUILDING RADIOCHEMICAL ENGINEERING CELLS AND HIGH-LEVEL VAULT CLOSURE PLAN}

\section{FORENORD}

The Hanford Facility is owned by the U.S. Government and operated by the U.S. Department of Energy, Richland Operations Office. Dangerous waste and mixed waste (containing both radioactive and dangerous components) are produced and managed on the Hanford Facility. The dangerous waste is regulated in accordance with the Resource Conservation and Recovery Act of 1976 and the State of Washington Hazardous Waste Management Act of 1976 (as administered through the Washington State Department of Ecology Dangerous Waste Regulations, Washington Administrative Code 173-303). The radioactive component of mixed waste is interpreted by the U.S. Department of Energy to be regulated under the Atomic Energy Act of 1954; the nonradioactive dangerous component of mixed waste is interpreted to be regulated under the Resource Conservation and Recovery Act of 1976 and Washington Administrative Code 173-303.

For purposes. of the Resource Conservation and Recovery Act of 1976 and the Washington State Department of Ecology Dangerous Waste Regulations, the Hanford Facility is considered to be a single facility: The single dangerous waste permit identification number issued to the Hanford Facility by the U.S. Environmenta1 Protection Agency and the Washington State Department of Ecology is U.S. Environmenta1 Protection Agency/State Identification Number WA7890008967.

The areas within the 324 Building covered by this closure plan are not covered by a Resource Conservation and Recovery Act of 1976 Part A, Form 3, Dangerous Waste Permit Application; however, the areas are being closed pursuant to the requirements for Resource Conservation and Recovery Act of 1976 closure for interim status TSD units as documented in the Hanford Federal Facility Agreement and Consent Order (Ecology et a1. 1996) as milestones (Milestones $M-89-00$ and $M-20-55$ ). Information provided in this closure $p l a n$ is current as of May 1997. 
DOE/RL-96-73, Rev. 0

$05 / 31 / 97$

This page intentionally left blank. 
FOREWORD

METRIC CONVERSION CHART

\subsection{INTRODUCTION}

2.0 FACILITY DESCRIPTION

3.0 PROCESS INFORMATION

4.0 WASTE CHARACTERISTICS

5.0 GROUNDWATER MONITORING

6.0 CLOSURE STRATEGY AND PERFORMANCE STANDARDS

7.0 CLOSURE ACTIVITIES

8.0 POSTCLOSURE

9.0 REFERENCES

\section{CONTENTS}

32 2A 324 BUILDING ENGINEERING DRAWINGS 
This page intentional ly left blank. 
ALARA

BCCP

CERCLA

CWC

DOE

DOE-RL

Ecology

EDL

EPA

FRG

HLV

ICP

LLV

LOS

Mci

NWVP

OU

PNL

PNNL

PUREX

$R \& D$

$R / h$

40 RCRA

41 REC

42 RI/FS

43 RLFCM

44 RLWS

45

46

TCLP

TRU

Tri-Party

Agreement

TSD

\section{LIST OF TERMS}

as low as reasonably achievable

324 Building B-Cell Safety Cleanout Project

Comprehensive Environmental Response, Compensation, and Liability Act of 1980

Central Waste Complex

U.S. Department of Energy

U.S. Department of Energy, Richland Operations Office

Washington State Department of Ecology

Engineering Development Laboratory

U.S. Environmental Protection Agency

Federal Republic of Germany

high-level vault

inductively coupled plasma

low-level vault

loadout station

million curies

Nuclear Waste Vitrification Project

Operable Unit

Pacific Northwest Laboratory

Pacific Northwest National Laboratory

plutonium-uranium extraction (process)

research and development

rad per hour

Resource Conservation and Recovery Act of 1976

radiochemical engineering cells

remedial investigation/feasibility study

Radioactive Liquid Fed Ceramic Melter

radioactive liquid waste system

toxicity characteristics leaching procedure transuranic

Hanford Federal Facility Agreement and Consent Order treatment, storage, and/or disposal 
1 WAC

2 WSEP

3

4 ZVDP
Washington Administrative Code

Waste Solidification Engineering Prototype Program

Zeolite Vitrification Demonstration Project 
METRIC CONVERSION CHART

\begin{tabular}{|c|c|c|c|c|c|}
\hline If you know & $\begin{array}{c}\text { Multiply } \\
\text { by }\end{array}$ & To get & If you know & $\begin{array}{c}\text { Multiply } \\
\text { by }\end{array}$ & To get \\
\hline \multicolumn{3}{|c|}{ Length } & \multicolumn{3}{|c|}{ Length } \\
\hline inches & 25.40 & millimeters & mil1imeters & 0.0393 & inches \\
\hline inches & 2.54 & centimeters & centimeters & 0.393 & inches \\
\hline feet & 0.3048 & meters & meters & 3.2808 & feet \\
\hline yards & 0.914 & meters & meters & 1.09 & yards \\
\hline miles & 1.609 & kilometers & kilometers & 0.62 & miles \\
\hline \multicolumn{3}{|c|}{ Area } & \multicolumn{3}{|c|}{ Area } \\
\hline $\begin{array}{l}\text { square } \\
\text { inches }\end{array}$ & 6.4516 & $\begin{array}{l}\text { square } \\
\text { centimeters }\end{array}$ & $\begin{array}{l}\text { square } \\
\text { centimeters }\end{array}$ & 0.155 & $\begin{array}{l}\text { square } \\
\text { inches }\end{array}$ \\
\hline square feet & 0.092 & $\begin{array}{l}\text { square } \\
\text { meters }\end{array}$ & $\begin{array}{l}\text { square } \\
\text { meters }\end{array}$ & 10.7639 & $\begin{array}{l}\text { square } \\
\text { feet }\end{array}$ \\
\hline $\begin{array}{l}\text { square } \\
\text { yards }\end{array}$ & 0.836 & $\begin{array}{l}\text { square } \\
\text { meters }\end{array}$ & $\begin{array}{l}\text { square } \\
\text { meters }\end{array}$ & 1.20 & $\begin{array}{l}\text { square } \\
\text { yards }\end{array}$ \\
\hline $\begin{array}{l}\text { square } \\
\text { miles }\end{array}$ & 2.59 & $\begin{array}{l}\text { square } \\
\text { kilometers }\end{array}$ & $\begin{array}{l}\text { square } \\
\text { kilometers }\end{array}$ & 0.39 & $\begin{array}{l}\text { square } \\
\text { miles }\end{array}$ \\
\hline acres & 0.404 & hectares & hectares & 2.471 & acres \\
\hline \multicolumn{3}{|c|}{ Mass (weight) } & \multicolumn{3}{|c|}{ Mass (weight) } \\
\hline ounces & 28.35 & grams & grams & 0.0352 & ounces \\
\hline pounds & 0.453 & kilograms & kilograms & 2.2046 & pounds \\
\hline short ton & 0.907 & metric ton & metric ton & 1.10 & short ton \\
\hline \multicolumn{3}{|c|}{ Volume } & \multicolumn{3}{|c|}{ Volume } \\
\hline $\begin{array}{l}\text { fluid } \\
\text { ounces }\end{array}$ & 29.57 & milliliters & milililiters & 0.03 & $\begin{array}{l}\text { fluid } \\
\text { ounces }\end{array}$ \\
\hline quarts & 0.95 & liters & Titers & 1.057 & quarts \\
\hline gallons & 3.79 & Titers & Titers & 0.26 & gallons \\
\hline cubic feet & 0.03 & $\begin{array}{l}\text { cubic } \\
\text { meters }\end{array}$ & $\begin{array}{l}\text { cubic } \\
\text { meters }\end{array}$ & 35.3147 & cubic feet \\
\hline cubic yards & 0.76 & $\begin{array}{l}\text { cubic } \\
\text { meters }\end{array}$ & $\begin{array}{l}\text { cubic } \\
\text { meters }\end{array}$ & 1.308 & $\begin{array}{l}\text { cubic } \\
\text { yards }\end{array}$ \\
\hline \multicolumn{3}{|c|}{ Temperature } & \multicolumn{3}{|c|}{ Temperature } \\
\hline Fahrenheit & $\begin{array}{l}\text { subtract } \\
32 \text { then } \\
\text { multiply } \\
\text { by } 5 / 9 \text { ths }\end{array}$ & Celsius & Celsius & $\begin{array}{l}\text { multiply } \\
\text { by } \\
9 / 5 \text { ths, } \\
\text { then add } \\
32\end{array}$ & Fahrenheit \\
\hline
\end{tabular}

Source: Engineering Unit Conversions, M. R. Lindeburg, PE., Second Ed., 1990, Professional Publications, Inc., Belmont, California.

The following conversion chart is provided to aid in conversion.

Into metric units

Out of metric units 
CONTENTS

5 1.0 INTRODUCTION ...................... . . . .

1-1 Hanford Facility ....................F1-1

1-2 300 Area . . . . . . . . . . . . . . . Fl-2

\section{FIGURES}


This page intentionally left blank. 


\subsection{INTRODUCTION}

The U.S. Department of Energy, Richland Operations Office (DOE-RL), the Washington State Department of Ecology (Ecology), and the U.S. Environmental Protection Agency (EPA) determined that mixed waste was stored in the Radiochemical Engineering Cells (REC) B-Cell and the High-Level Vault (HLV) of the 324 Chemical Engineering Building (324 Building), located in the 300 Area on the Hanford Site (Figures $1-1$ and $1-2$ ). The Parties agreed through the Hanford Federal Facility Agreement and Consent Order (Tri-Party Agreement) (Ecology et a1. 1996) to close certain identified areas of the 324 Building.

Tri-Party Agreement Milestone M-89-00, signed July 28, 1995 (Appendix 1A), identified the following areas of the 324 Building (B-Cell, D-Cel1, and the HLV) as requiring closure:

- Milestone M-89-01, completed October 1996, identified the HLV tanks that contained mixed waste as tanks 104, 105, and 107, and directed the DOE-RL to flush and drain these tanks.

- Milestone M-89-02, due May 1999, requires removal of B-Ce11 mixed waste and equipment.

- Milestone M-89-03, completed in March 1995, required compliance with interim status facility standards for the nonpermitted 324 Building areas. Because of the high radiation fields associated with mixed waste stored in the REC and HLV, alternative compliance measures for some interim status requirements were employed.

- Milestone M-89-04, completed in June 1995, required DOE-RL to identify mixed waste management alternatives.

Milestone M-20-55 required the submittal of a closure $p l a n$ for the above identified areas of the 324 Building. This milestone was satisfied with the submittal of the initial version of this closure plan to Ecology in December 1995. This revised document is being prepared to resolve comments and issues with the initial closure plan, to reflect the change in building mission and management, and to provide better integration of closure activities with building stabilization and decontamination activities, and with the CERCLA remedial actions for the 300 Areas operable units (OU).

General requirements for Resource Conservation and Recovery Act (RCRA) of 1976 closure are discussed in the Tri-Party Agreement. These requirements state that "al1 [treatment, storage and/or disposal] TSD units that undergo closure, irrespective of permit status, shall be closed pursuant to the authorized State Dangerous Waste Program in accordance with WAC 173-303-610." 
1 All areas of the 324 Building were considered when defining the boundary 2 for closure (Ecology 1997). Areas of the tuilding that were not used for TSD 3 activity will not have TSD requirements imposed on them for closure. This 4 closure plan only addresses TSD activities that have occurred within the 5 closure boundary (Chapter 2.0, Section 2.1). 


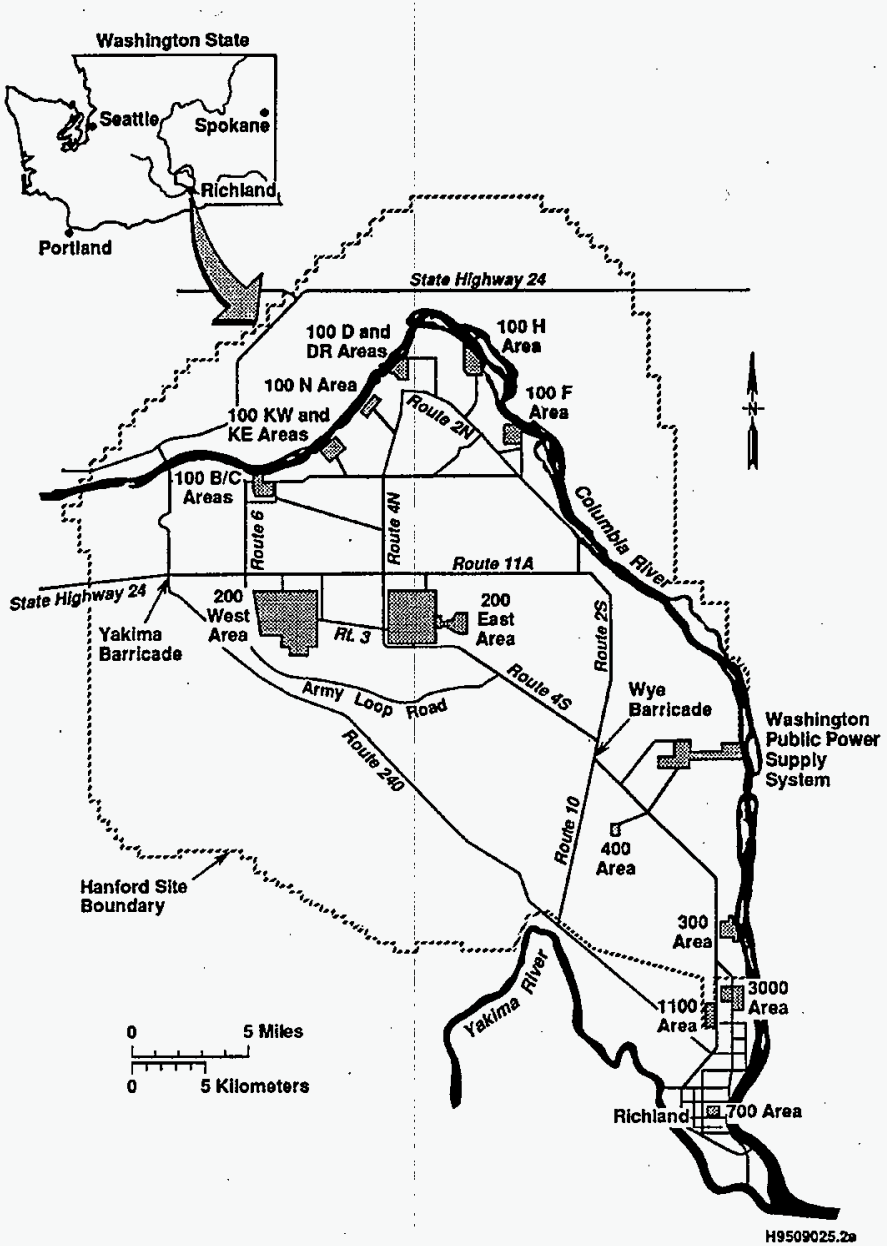

Figure 1-1. Hanford Facility. 


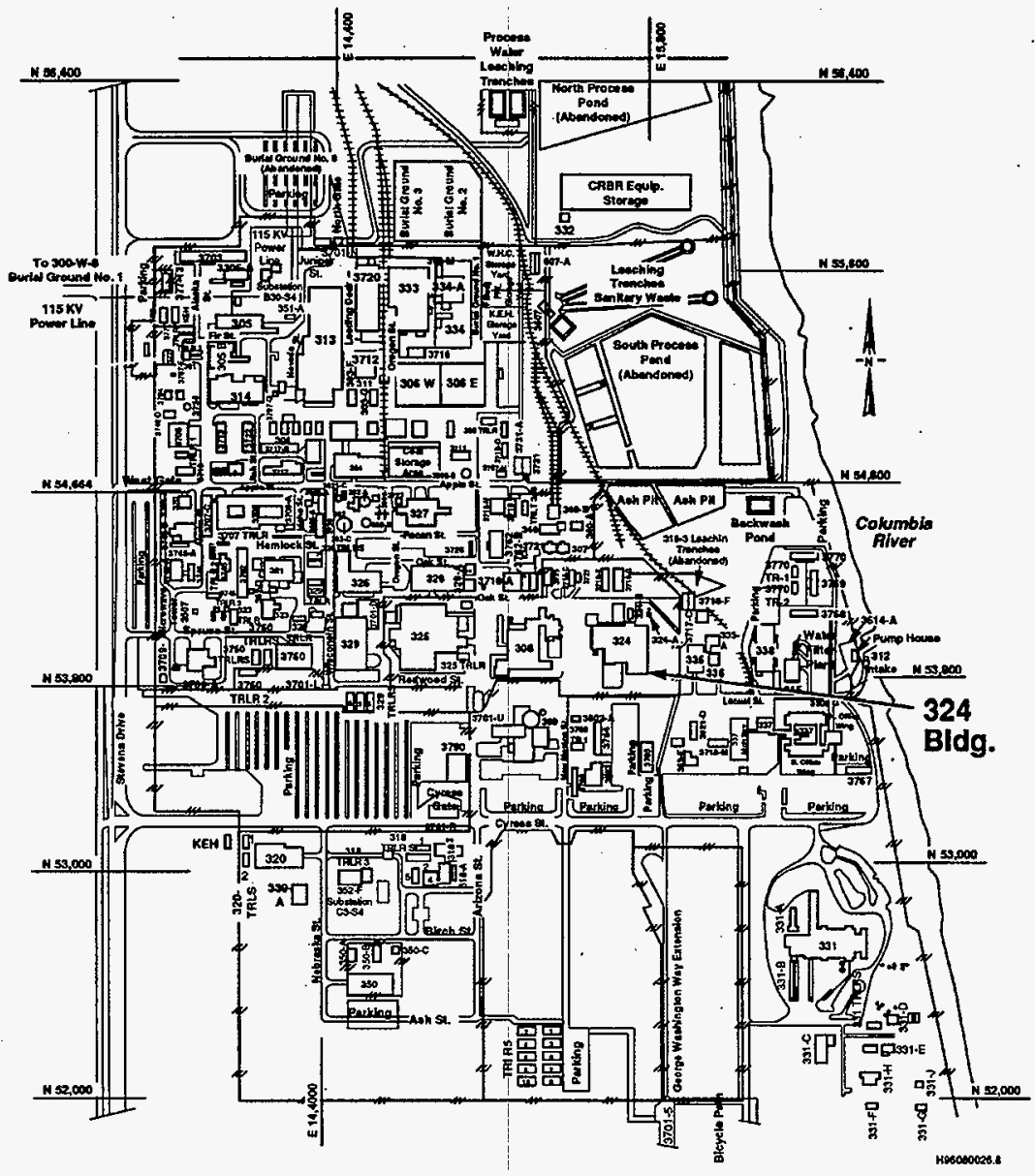

Figure 1-2. 300 Area and Location of 324 Building. 


\section{CONTENTS}

2.0 FACILITY DESCRIPTION . . . . . . . . . . . . 2-1

2.1 ClOSURE UNITS BOUNDARIES .................. 2-

2.2 GENERAL DESCRIPTION OF THE 324 BUILDING RADIOCHEMICAL

ENGINEERING CELLS ................... 2-1

$2.2 .1 \quad \mathrm{~A}-\mathrm{Cell} \ldots \ldots . . . . . . . . . . .2-2$

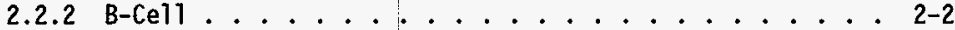

$2.2 .3 \quad$ C-Cell ........................ 2-3

2.2 .4 D-Cell ...................... 2-3

2.2 .5 Airlock ................... 2-3

2.2 .6 Pipe Trench ............... 2-. 24

2.2.7 Other Radiochemical Engineering Cells Components . . . 2-4

2.3 DESCRIPTION OF HIGH-LEVEL VAULT AND LOW-LEVEL VAULT . . . . 2-4

2.3.1 High-Level Vault and High-Level Vault Tanks ..... 2-5

2.3.2 Low-Level Vault and Low-Level Vault Tanks ....... 2-6

2.3.3 Sample Room (Room 145) ........... 2-7

2.4 DESCRIPTION OF THE PIPING SYSTEM .......... . . 2-7

2.4.1 General Characteristics of the Piping System . . . 2-7

2.4.2 Piping into the Radiochemical Engineering Cells, the

High-Level Vault, and the Low-Level Vault . . . . 2-8

2.5 OTHER 324 BUILDING AREAS . . . . . . . . . . . . 2-9

2.5.1 Cask Handling Area . . . . . . . . . . . . . 2-9

2.5.2 Trucklock ............... . . 2-9

2.5.3 Engineering Development Laboratory-146 (Room 146) . . . 2-10

2.5 .4 Galleries ................ 2- . . . . . . .

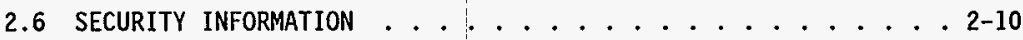


2-1 Cut-away of the 324 Building showing the High-Level Vault, Low-Leve1

2-2 324 Building Basement Plan . Engineering Cells . . . . . . . . . F2-1

2-3 324 Building First Floor Plan ... . . . . . . . . . . F2-3

2-4 324 Building Second Floor Plan .................. F2-4

2-5 324 Building Third Floor Plan ................ F2-5

2-6. 324 Building Cross-section Through the High-Level Vault, Low-Leve] Vault, Airlock, and B-Cell .............. F2-6

2-7 Overail Planning for 324 Building Radiochemical Engineering Celis : F2-7

2-8 324 Building High-Level Vault, Low-Level Vault, and Vault Tanks. . F2-8

2-9 324 Building High-Level Vault Cross-section ........... F2-9

2-10 324 Building High-Level Vault Construction Photograph Before Sealing the Cover Blocks ......... F2-10

2-11 324 Building High-Level Vault Construction Photograph Before Sealing the Cover Blocks ............... F2-11

2-12 324 Building Low-Level Vault Construstion Photograph Before Sealing the Cover Blocks ................. F2-12

2-1 Areas Undergoing Closure......

TABLES

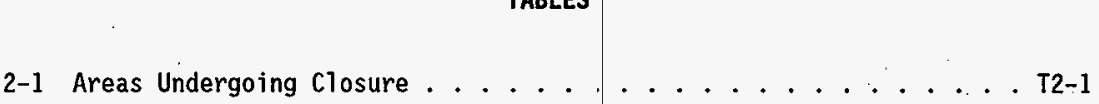


DOE/RL-96-73, Rev. 0

$05 / 31 / 97$

\subsection{FACILITY DESCRIPTION}

Construction of the 324 Building began in 1964 and was completed in 1965 . The physical dimensions of the 324 Building are 62.5 meters by 71.6 meters in area and 13.7 meters in height above ground level. The building has a partial basement and first, second, and partial third floors, totaling approximately 9,450 square meters of floor area. The foundation structure is poured-inplace reinforced concrete.

The 324 Building (Figures 2-1 to 2-6) provides office and 1aboratory space for scientific and engineering staff who conduct multi-disciplinary research in areas of waste characterization and immobilization, waste remediation and cleanup development, biomass research, spent fuel characterization, tritium development, and cesium chloride encapsulation. Because the 324 Building houses research and development activities, the work being conducted changes as programs are concluded and other programs are started. Currently, most processes that involve the REC, HLV, and LLV have been discontinued (refer to Chapter 3.0).

\subsection{CLOSURE UNITS BOUNDARIES}

Through negotiations between DOE-RL and Ecology (Ecology 1997), it was determined that the closure unit boundary will include all the cells in the REC (A-Cel1, B-Cel1, C-Ce11, D-Ce11), the airlock, the pipe trench, the HLV, the LLV, the trucklock, the cask handling area, the sample room (Room 145), the Engineering Development Laboratory-146 (EDL-146) (Room 146), and the galleries. Figures 2-2 to 2-5 identify the closure unit boundaries. This closure plan addresses TSD activities that have taken place within this closure boundary. Additionally, Ecology and DOE have agreed (Ecology 1997) that the ventilation system is not included in the closure and that the system will remain operational under Washington State Department of Health direction and compliance requirements as appropriate.

However, DOE-RL and Ecology also agreed that the only portions of the 324 Building that require closure actions are: (1) the B-Cell, (2) two portions of the D-Cel1: the waste oil drum storage area and the HLV liquid treatment process equipment, (3) the airlock, (4) the pipe trench, (5) the HLV, (6) the LLV, (7) the HLV sample room (Room 145), (8) the EDL-146, and (9) the galleries. The strategy and activities required for closure of these portions of the 324 Building are detailed in Chapters 6.0 and 7.0 , respectively. Sections 2.2 through 2.5 give a general physical description of the portions of the 324 Building that are included in the closure boundary. Areas undergoing closure are identified in Table 2-1.

\subsection{GENERAL DESCRIPTION OF THE 324 BUILDING RADIOCHEMICAL ENGINEERING CELLS}

The 324 Building REC (Figures 2-1 to 2-5 and 2-7) consists of four hot cells (A-Ce11, B-Cel1, C-Cell, and D-Ce11), a central airlock, and a 
pipetrench. The cells and airlock are joined to form a T-shaped structure. The $\mathrm{D}-\mathrm{Ce} 1 \mathrm{l}$ is located above the $\mathrm{C}-\mathrm{Ce} 11$ on the south side. The $\mathrm{C}-\mathrm{Ce} 11 / \mathrm{D}-\mathrm{Ce} 11$, the airlock, and the A-Cell form the top of the T-shape. The B-Cell connects to the airlock to form the bottom of the T-shape. The walls are constructed of 1.2-meter-thick high-density concrete on 1.4-meter-thick, normal-density concrete. This concrete is used as containment and radiation shielding. Additional drawings are provided in Appendix $2 A$.

Operations in the REC are performed remotely. Each cell is equipped with manipulators; remotely operated cranes; remote viewing equipment; and 1.2-meter-thick leaded glass viewing windolss with mineral oil, which acts as an optical clarifier, so that experiments can be carried out remotely.

\subsubsection{A-Cel1}

The A-Cell (Figures 2-3 and 2-7) is 2.82 meters long, 6.4 meters wide, and 10 meters high. The floor of the cell is located at the first floor level. The floor is lined with 0.32 -centimeter stainless steel plate that is welded at the seams. Under the floor plate is a 15-centimeter-thick slab of concrete, and under the concrete is a crawilspace and packed native soil. Cell access is through a door into the airlock. Shielding walls are constructed of 1.4-meter-thick, normal-density concrete. Normal services into A-Cell include electricity, water, and compressed air.

\subsubsection{B-Cell}

The B-Cell (Figures 2-2 and 2-7) is the largest of the four hot cells, measuring 7.6 meters long, 6.7 meters. wide: and 9.3 meters high. The floor of the cell is located at approximately the bisement level. The floor and the walls up to 8.2 meters high are lined with 0.32 -centimeter stainless steel plate that is welded at the seams. Under the floor plate is a 15-centimeterthick slab of concrete, and under the concrete is packed native soil. The cell walls are made of 1.2-meter-thick high-density concrete. The cell is surrounded on three sides by operating galleries on the first and second floors and on two sides by a gallery at the basement level. The east side of the cell adjoins the airlock.

The B-Cell floor was constructed with a 2-percent slope from the high point along the west side to the low point on the east side. Any liquid that reaches the floor drains across the floor tio a trench, which runs the length of the east side, that is sloped to a sump in the northeast corner. The cell is equipped with an alarm that annunciates if excess liquid accumulates. However, liquid material in the sump has been allowed to evaporate in the past because of the small amount of material accumulated and the high evaporation rate inside the cell.

Penetrations for services, such as maripulators and electrical cables, are not completely sealed, but rather rely on the negative pressure in the cell to prevent escape of contamination. Ventilation inlets initially were 
designed and installed with low-efficiency filters (dust stops), but those filters admitted particulate matter from the outside, some of which settled to the floor as it entered the slower moving air in the cell. In April 1994, high-efficiency particulate air (HEPA) filters were installed to minimize the amount of dust entering the cell. The HEPA filters remove at least 99.97 percent of 0.3-micron-size particles. Air leaving the B-Cell passes through an electrostatic precipitator upstream from a bank of in-cell HEPA filters. The air exhaust passes through two additional banks of HEPA filters before leaving the building.

\subsubsection{C-Cel1}

The C-Cell is located directly below D-Cell in the south leg of the REC ' $\mathrm{T}$ ' (Figures 2-3 and 2-7). The floor of the cell is at the first floor building level. The C-Cell is 5.88 meters long, 3.7 meters wide, and 4.6 meters high. The floor is lined with 0.32 -centimeter stainless-steel plate welded at the seams. Under the floor plate is a 15-centimeter-thick slab of concrete, and under the concrete is a crawlspace and packed native soil. The cell is adjoined to the north by the airlock. The cell access is provided by a door to the airlock. Shielding walls are constructed of 1.2-meter-thick high-density concrete. Normal services into C-Cell include electricity, water, and compressed air.

\subsubsection{D-Cell}

The $\mathrm{D}-\mathrm{Ce} 1 \mathrm{l}$ is located directly above $\mathrm{C}-\mathrm{Cell}$ in the south end of the REC ' $T$ ' (Figures 2-5 and 2-7). The floor of the cell is between the second and third floor levels. The REC D-Celi is 6.1 meters long, 3.7 meters wide, and 4.9 meters high. The floor is lined with 0.32 -centimeter-thick stainless steel, and the walls are lined with carbon steel and coated with protective paint. The cell is adjoined by the airlock and by the second floor service gallery on the south side. There is a door between the cell and the airlock. Shielding walls are constructed of 1.2-meter-thick high-density concrete. Normal services into D-Cell include electricity, water, and compressed air.

\subsubsection{Airlock}

The airlock is located at the junction of the arms of the REC ' $T$ ' (Figure 2-7) and is 6.7 meters long, 6.55 meters wide, and 10 meters high. The floor and the walls up to 8.2 meters high are lined with stainless steel plate welded at the seams. The airlock adjoins the A-Cell (north), the B-Cell (west), and the C-Cell/D-Cell (south), and the cask handling area (east). Access to these areas is via large steel interlocked doors. The airlock is equipped with cranes that facilitate remote installation, maintenance, and operation of equipment. Shielding walls are constructed of 1.4-meter-thick, normal-density concrete. 


\subsubsection{Pipe Trench}

The pipe trench is located under the floor of the REC airlock just in front of the B-Cell door. The pipe trench is 1.3 meters wide, 6.4 meters long, and varies in depth from approximately 1.8 meters on the north end. The pipe trench can be accessed by removing the 60-centimeter-thick cover blocks. The pipe trench is used to make process connections for the radioactive liquids being handled by the cells and the vaults. Examples of the connections include transfer lines to and from the vaults, lines to the loadout station (LOS), and lines to B-Cell. Also, various utility connections (chemical addition lines, air lines, and steam lines) can be made in the pipe trench. Additional information on the overall piping system is given in Section 2.4 .

\subsubsection{Other Radiochemical Engineering Cel'/s Components}

Two other components of the REC are of concern for closure. These are the pass-through ports and the cubicles.

2.2.7.1 Pass-through Ports. The pass-through ports are holes in the hot cell walls (ranging from 10 to 38 centimeters in diameter) that are used to pass items into the hot cells. The smaller port:s generally are equipped with 'split plugs,' which have shielding on the bottom for half of one plug and on the top half for the other half of the plug. This allows hoses and cords to be placed through the wall into the hot ce:1. The larger ports generally are equipped with shielding doors and are used to pass objects, such as tools or equipment, into (and possibly out of) the cel1.

2.2.7.2 Cell Cubicles. Cell cubicles are located in the walls of A-Cell and B-Cel1. The cubicles consist of a 10-cent meter-thick steel shielding door that opens into a small area in the wall. The cubicles do not penetrate the cell walls. The cubicle areas are used for making process connections (e.g., for steam, air, water, chemical addition) into the cells.

Eight cubicles are associated with A-ciel1 and B-Ce11. Cubicles A-11 and A-12 are located on the first floor of the A-CelT gallery. Cubicles $A-21$ and $A-22$ are located on the second floor. Cubicles $A-31$ and $A-32$ are located on the third floor. Cubicles B-12 and B-14 are located on the first floor B-Cell gallery, west wall (Figure 2-7).

\subsection{DESCRIPTION OF HIGH-LEVEL VAULT AND LOH-LEVEL VAULT}

Two shielded underground vaults are in the 324 Building: HLV and LLV (Figures 2-1, 2-6, and 2-8). These vaults are equipped for temporary storage of radioactive liquid. Each vault contains four stainless steel tanks. These tanks have been used as temporary holding tanks for feed solutions, feedstock tanks for process solutions, or collection tanks for effluents from project 
activities. The HLV is used to store highly radioactive liquid, including mixed waste solutions. The LLV is used to store solutions with low to intermediate levels of radioactivity including mixed waste solutions.

\subsubsection{High-Level Vault and High-Level Vault Tanks}

The HLV is located under the floor of the cask handling area. The HLV is 6.4 meters long, 4.0 meters wide, and 4.4 meters deep. A ledge approximately 1.4 meters high at one end enlarges the upper level of the HLV to 8.2 meters long. The HLV contains four stainless steel tanks (104, 105, 106, and 107) (Figures 2-1, 2-6, 2-8, 2-9, 2-10, and 2-11). The smallest tank has a capacity of approximately 1,700 liters and the largest tank has a capacity of approximately 18,000 liters.

The HLV is constructed of concrete and is lined partially with a welded 0.32 -centimeter stainless steel plate. The plate, which provides secondary containment, covers the floor and extends 1.1 meters up the walls. The stainless steel plate also covers the floor of the ledge and extends 15.2 centimeters up the walls above the ledge. The floor is sloped in the shortest direction toward a trench located along the north wall. The trench, in turn, slopes from both ends of the HLV toward the middle where a 0.6-meter by 0.6 -meter by 0.6 -meter sump is located. The sump is equipped with a liquid-sensing alarm and a steam jet to transfer liquids to tank 104.

The HLV is covered by concrete 1.8 meters thick. The concrete shields against radiation to minimize exposure to workers outside of the HLV. The HLV can be accessed from above by removal of the cover blocks, which cover about 40 percent of the vault floor area. Beneath the concrete cover blocks are removable steel plate ventilation barriers.

Each tank is a cylinder with a flat roof and sloped floor (except for tank 107, which has a concave floor) and a stainiess-steel cooling jacket. The HLV tanks are fitted with bubbler tubes with differential pressure transducers for measuring liquid level, specific gravity, and static pressure and with thermocouples for measuring temperature. Instrument readings are logged each normal working day. The tanks al so are equipped with high-liquidlevel and high-temperature alarms, except tank 106, which does not have a high liquid level alarm. Because the stainless-steel cooling jackets are not being used, air now fills the space between each tank and its shell. All tanks are operated at slightly negative pressure, are vented through a common ventilation system that pulls air and tank vapors through two banks of HEPA filters, and are discharged to the main 324 Building stack.

When the HLV tanks were installed in 1964, the tanks included the following design features to provide protection against releases of waste to the environment: corrosion-resistant stainless steel tanks and piping; welded pipe connections; tanks with top-entering penetrations on $7 y$; secondary containment around tanks and piping; and instruments to control the fill level of the tanks and to detect leaks. Specific design details and ancillary equipment are described in the following sections. 
2.3.1.1 Tank 104. Tank 104 was built in 1954 and originally installed in the 321 Building. The tank is 2.7 meters in diameter by 2.7 meters high, has a capacity of 14,800 liters, and is constructed of 1.27-centimeter-thick Type $304 \mathrm{~L}$ stainless steel. Tank 104 rests on 18 stainless steel legs arranged in two concentric circles. In 1964, the tank was modified for use in the HLV and moved to its present location. As part of the modification, all of the circumferential-shel7 and long-seam welds ivere radiographed to ensure the integrity of the tank. Additionally, the lank was leak tested by filling the tank with water, and the cooling jacket hydrostatically was tested to 137.9 kilopascals gauge.

2.3.1.2 Tank 105. Tank 105 was built in : 1943 and was installed in the 321 Building in approximately 1950 . Tank : 05 is 2.9 meters in diameter and 2.7 meters high and has a design capacity of 18,000 liters. The tank and its cooling jacket are constructed of 1.27-cent:imeter-thick Type 309 Columbium stainless steel. In a manner similar to tank 104, tank 105 was modified for use in the HLV and moved to its present loc:ation in 1964. At that time, all of the circumferential-shell and long-seam welds were radiographed; the tank was leak tested by filling the tank with water; and the cooling jacket hydrostatically was tested at 137.9 kilopasicals gauge.

2.3.1.3 Tank 106. Tank 106, constructed in 1944, is 1.2 meters in diameter by 1.5 meters high and has a capacity of 1,700 liters. Tank 106 rests on the ledge beside tank 107. The tank walls and bottom are made of 0.64 -centimeter Type 309 Columbium stainless steel plate; the cooling jacket is made of 0.48-centimeter Type 25-12 Columbium stainless steel; and the roof is made of 0.95-centimeter Type 18-8 Columbium stainleiss steel.

2.3.1.4 Tank 107. Tank 107 is made of 0.6i4-centimeter-thick Type 304L stainiess steel and was subjected to radiography and dye-penetration testing of the welds when built in 1963. Tank 107 is supported by three legs and rests on the ledge beside Tank 106. Tank 107 is 1.7 meters in diameter by 1.8 meters high and has a capacity of $3,60 c$ liters. The tank cooling jacket extends 1.1 meters above the base of the tank.

\subsubsection{Low-Level Vault and Low-Level Vault Tanks}

The LLV is located under the floor of Room 147. Room 147 is used for repair of radioactively contaminated equipment. The LLV contains

four stainless steel tanks (tanks 101, 102, 103, and 108) (Figures 2-1, 2-6, $2-8$, and 2-12). The LLV is 8.7 meters wide, 4.0 meters 10 g, and 5.6 meters deep. The LLV is constructed of concrete with the walls and floor 7 ined with 0.32 -centimeter stainless steel sheet or plate that extends 1.2 meters up from the highest point of the floor.

The floor of the LLV is sloped in the shortest direction toward a trench that is located along the west wall. The trench slopes from both ends toward a 0.6 -meter by 0.6 -meter by 0.3 -meter sump. The sump is equipped with liquid sensing alarms and pumps to transfer liquid to other tanks in the system. 
The LLV is covered by concrete shielding blocks that are 0.6 meters thick, but is accessible from above through a set of concrete cover blocks that cover about 40 percent of the floor area. Beneath the cover blocks are removable steel $\mathrm{plate}$ ventilation barriers.

The four tanks in the LLV were built in 1943 and were subsequently modified in 1963 for use in the LLV. All of the circumferential-she11 and long-seam welds were radiographed following modification. Additionally, the tanks were leak tested by filling with water after the modifications were completed. As are the HLV tanks, the LLV tanks are fitted with bubbler tubes with differential pressure transducers for measuring liquid level, specific gravity, and static pressure and with thermocouples for measuring temperature. Instrument readings are logged each normal working day. The tanks also are equipped with high-liquid-level and high-temperature alarms.

These tanks $(101,103$, and 108) are 2.0 meters in diameter and 4.3 meters high. Tanks 101 and 103 each have a capacity of 12,500 1 iters; tank 108 has a capacity of 12,000 1iters. The tanks are constructed of 1.27-centimeter-thick Type 309 Columbium stainless steel with a 0.32 -centimeter-thick Columbium stainless steel cooling jacket to enable circumferential heating and cooling of the tank. The tanks rest on 18 pads placed in two concentric circles about the longitudinal axis of the tank and one in the center. The roof of each tank is flat and the floor is sloped.

Tank 102 is similar to the other tanks in the LLV. However, tank 102 is 2.4 meters in diameter and 4.3 meters high and has a capacity of 18,500 liters.

\subsubsection{Sample Room (Room 145)}

The sample room (Room 145) contains sampling equipment for the HLV and LLV tanks. The sample room is a 2.7 -meter by 1.8 -meter by 2.6 -meter metal enclosure with a concrete-shielded roof located in the northwest corner of the EDL-146. Inside the sample room is a containment box that has vacuum sampling lines to the LLV and HLV tanks.

\subsection{DESCRIPTION OF THE PIPING SYSTEM}

The piping system within the 324 Building serves a variety of functions, with separate lines for liquid transfers, tank sampling, tank venting, and sparging. The piping system includes the normal utilities, chemical addition lines, raw (cooling) water supply lines, raw water return to the retention process sewer, instrument air lines, and steam 1 ines.

\subsubsection{General Characteristics of the Piping System}

The piping associated with the REC and the two vaults varies from $1 / 4$ inch to 3 inches in diameter and is made of stainless steel with welded 
joints. At the time of installation in 1964/1965, all building piping was pressure tested at 21 kilopascals and at 1724 kilopascals. (water and steam), respectively, and did not experience pressure loss in a 24-hour period.

Liquids are moved using jets. Unlike pumps, jets essentially are maintenance free. The jets function by creating a suction that draws the liquid to the desired location. The steam jets can be used to move liquids between the vaults and the REC, between cells, between tanks in the vaults, and between the vaults. Air jets are used to collect samples from the vault tanks.

Gravity also is used for moving the 1 iquids. The piping that enters the vaults drains to the vault tanks by gravity fịow. The gravity piping system was designed with a fall of 0.063 inch per foot of run. "This slope yields a flow capacity of 30 liters per minute for the 1.5-inch-diameter pipe and 60 liters per minute for the 2-inch-diameter pipe. Instrumentation piping, vent piping, sparging piping, and sampling piping have a continuous upward slope from the vault tanks to eliminate the potential for siphoning in these piping systems.

The piping in the building is encased only where it passes through a concrete structure; at these points, a 4-inch-diameter fiberglass reinforced epoxy pipe surrounds the piping. Within the two vaults, the piping was constructed above the tanks in the vault. The vault serves as secondary containment in the event that a pipe leak should develop. Outside of the vaults, there is no specific secondary containment for most of the piping system other than the structural concrete of the building's floor and walls; however, for some of the piping to the HLV, secondary containment consists of a 12-inch stainless steel pipe.

\subsubsection{Piping into the Radiochemical Enginiering Cells, the High-Level Vault, and the Low-Level Vault}

Connections to the piping into the REV, the HLV, and the LLV are located throughout the 324 Building. The location of the specific connections depends on the type of material being handled. Piping connections that handle nonradioactive material (e.g., instrument air, steam, and chemical addition lines) are located in the galleries surrounding the REC. Piping connections for radioactive or potentially radioactive materials are located in shielded locations, such as the pipe trench and the cell cubicles.

Some of the piping into the REC and the vaults are dedicated, single-use connections. Examples of dedicated, single-use connections for nonradioactive materials are the instrument air lines into the vaults. Examples of dedicated, single-use connections for radioactive materials include the sample lines from the vault tanks to the HLV sample room (Room 145) and the drains from the cell cubicles to the HLV.

Other piping into the REC and the vauilts has been designed to allow interconnections among different piping to be made depending on the needs of a 
specific project or task. Normally, several different pipes come together at a specific location. Examples of piping that allow interconnections for handling radioactive materials include the piping in the pipe trench (under the floor of the REC airlock), which allows connections between vaults and B-Ce11, cell cubicles, and LOS. The LOS is used to load and unload casks containing radioactive liquids.

\subsection{OTHER 324 BUILDING AREAS}

The following four other areas are of importance within the closure boundary: cask handling area, trucklock, EDL-146, and galleries.

\subsubsection{Cask Handling Area}

The cask handling area (Figure 2-3) is 10.4 meters by 20.1 meters by 10.7 meters.high. The floor of the cask handing area is concrete. The cask handling area is adjoined to the west by the REC, to the east by the EDL (Room 146) and Room 147, to the north by the trucklock, and to the south by the shielded materials area. The HLV is located under the floor. The cask handling area provides access into the airlock via a steel door. An overhead bridge crane (27.22 metric ton capacity main hoist and 4.54 metric ton capacity auxiliary hoist) spans the east-west dimension of the cask hand ing area. This crane also services the trucklock.

\subsubsection{Trucklock}

The trucklock (Figure 2-3) is located to the north of the cask handling area. The trucklock is 11 meters by 10.4 meters by 10.7 meters high. Trucks, trailers, and train cars that are 9.2 meters long can be accommodated. outside access into the trucklock is via a 3.7-meter-wide by 3.05-meter-high vertically sliding door.

A large, roll-up door is at the top of the partition wall between the cask handling area and trucklock. The crane (Section 2.7.1) can enter the trucklock via this door. A 3.05-meter-wide, full-height double swinging door separates the cask handling area and the trucklock. The double swinging door allows for large material to be moved into or out of the cask handling area.

Also located within the trucklock is a decontamination and cask load-out stall. The stall is a 2.13-meter-long, 1.52-meter-wide, and 3.05-meter-high steel and stainless enclosure. Large front and top doors provide access to the stall. The stall is used to handle casks that transport radioactive liquids. Specifically, the stall is used to radiologically decontaminate the exterior of the casks. 
The EDL-146 (Figure 2-3) is a large unshielded room that is

\subsubsection{Galleries}

The basement, first floor, second flour, and third floor galleries (Figures 2-2 to 2-5) are the personnel access spaces around the REC. operating stations for the remote equipment: with viewing windows are located in the galleries for the REC. Various utility lines (steam, water, air, chemical addition) are available in the galleries for connecting to the REC. The galleries also provide access to $\mathrm{A}-\mathrm{Cel}$ and $\mathrm{B}-\mathrm{Cell}$ cubicles.

In the basement, galleries provide access to the south and west exterior of B-Cell. On the first floor, galleries provide access to the south exterior of $\mathrm{C}-\mathrm{Ce} 11$, the south, west, and north exteriors of $\mathrm{B}-\mathrm{Cell}$, and the north exterior of A-Cell. On the second floor, salleries provide access to the south exterior of D-Cell, the south, west, and north exterior of B-Ce11, and the north exterior of A-Cell. On the third floor, galleries provide access to the south exterior of $\mathrm{D}-\mathrm{Cell}$ and the north exterior of $\mathrm{A}-\mathrm{Cell}$.

\subsection{SECURITY INFORMATION}

Security information for the Hanford Facility is discussed in the Hanford Facility Dangerous Waste Permit Application, General Information Portion (DOE/RL-91-28).

A11 persons entering the 300 Area must display a DOE-issued security identification badge indicating appropriate authorization. Personnel are subject to random searches of items carried into and out of the 300 Area. Signs posted at the 300 Area boundaries inside the Hanford Site state

NO TRESPASSING. SECURITY BADGES REQUIRED BEYOND THIS POINT. GOVERNMENT VEHICLES ONLY. PUBLIC ACCESS PROHIBITED

or an equivalent legend.

The 324 Building is locked at all times, and access is limited to staff with keys or proximity cards; badged visitcrs must contact their host from the door to gain entry. Signs describing entry requirements and escort policy are posted at the entry. Inside the 324 Building, the lobby and first and second floor offices are the only nonradiologically controlled areas. Access to the REC, HLV, and other radiologically controlled areas is restricted. Entry codes are required for access. Staff entering any such area must have had specific training and proper approval. 
Table 2-1. Areas Undergoing Closure

\begin{tabular}{|c|c|c|}
\hline AREA & $\begin{array}{l}\text { REQUIRE } \\
\text { CLOSURE } \\
\text { ACTIVITIES } \\
\end{array}$ & COMPONENTS FOR CLOSURE \\
\hline A-Cel11 & No & $N / A$ \\
\hline B-Cell & YES & Tiner, concrete \\
\hline C-Cel1 & NO & $N / A$ \\
\hline D-Cell & YES & $\begin{array}{l}\text { waste drum storage area; } \\
\text { HLV liquid treatment process equipment } \\
\text { area }\end{array}$ \\
\hline Airlock & YES & isolate from HLV \\
\hline Pipe Trench & YES & isolate from HLV \\
\hline HLV & YES & four tanks, piping, liner, concrete \\
\hline LLV & YES & four tanks, piping, liner, concrete \\
\hline $\begin{array}{l}\text { HLV Sample Room } \\
\text { (room 145) }\end{array}$ & YES & isolate from $\mathrm{HLV}$ and $\mathrm{LLV}$ \\
\hline $\begin{array}{l}\text { Cask Handling } \\
\text { Area }\end{array}$ & NO & N/A \\
\hline Trucklock & NO & N/A \\
\hline EDL-146 & YES & isolate from $H L V$ and $L L V$ \\
\hline Galleries & YES & $\begin{array}{l}\text { isolate HLV and LLV from chemical make- } \\
\text { up room }\end{array}$ \\
\hline
\end{tabular}


DOE/RL-96-73, Rev. 0 $05 / 31 / 97$

This page intentional ly left biank. 
DOE/RL-96-73, Rev. 0

$05 / 31 / 97$

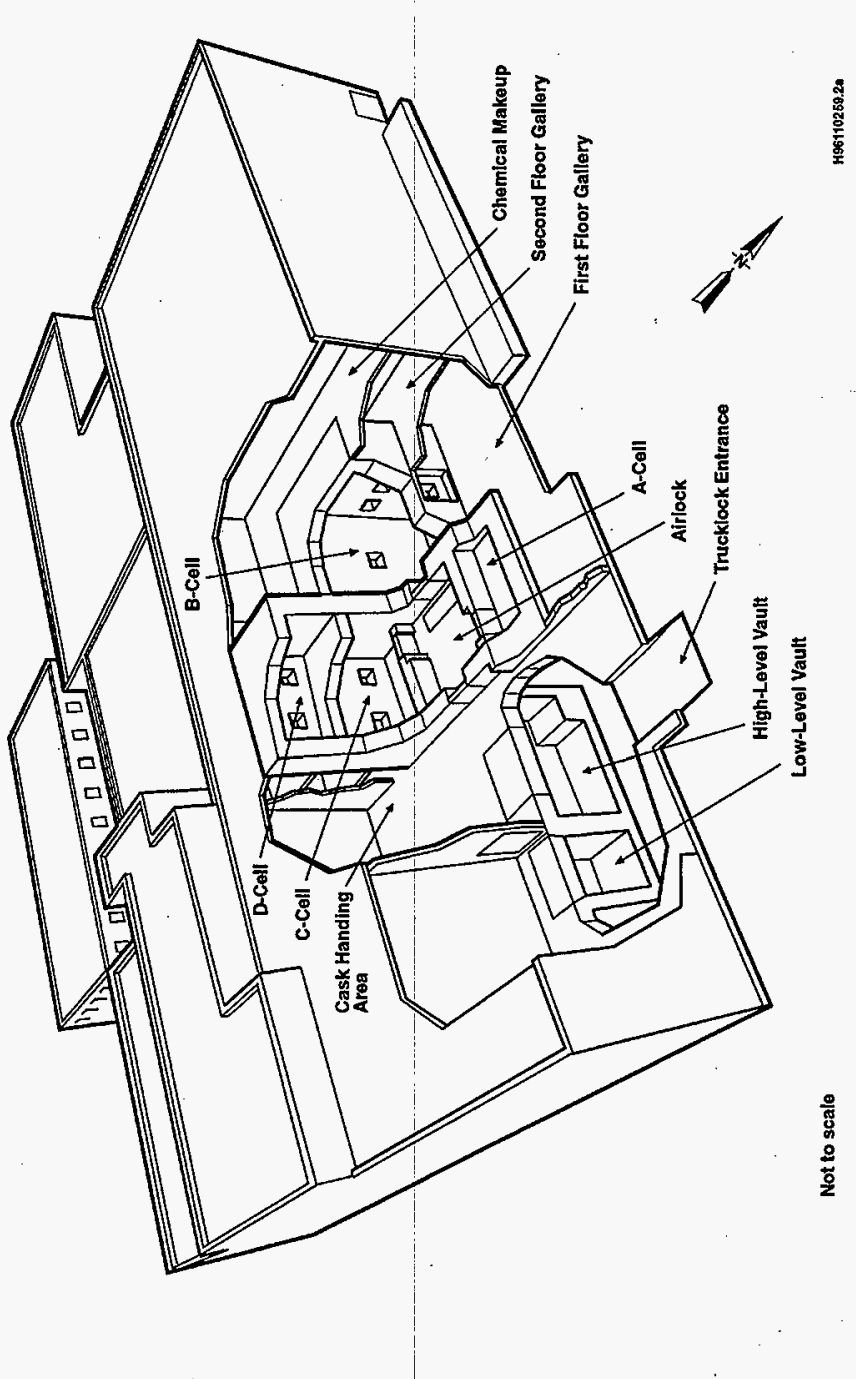

Figure 2-1. Cut-away of the 324 Building showing the High-Level Vault, Low-Level Vault, and the Radiochemical Engineering Cells. 


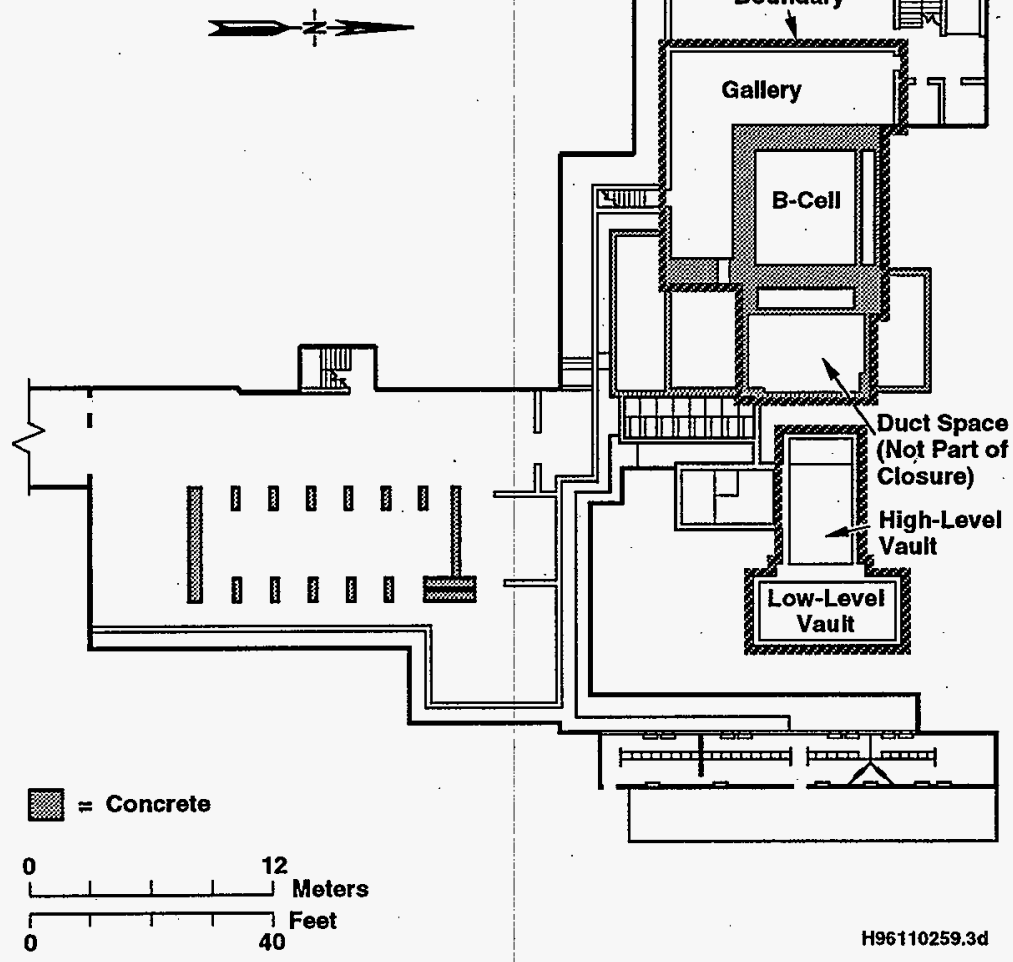

Figure 2-2. 324 Building Basement Plan. 


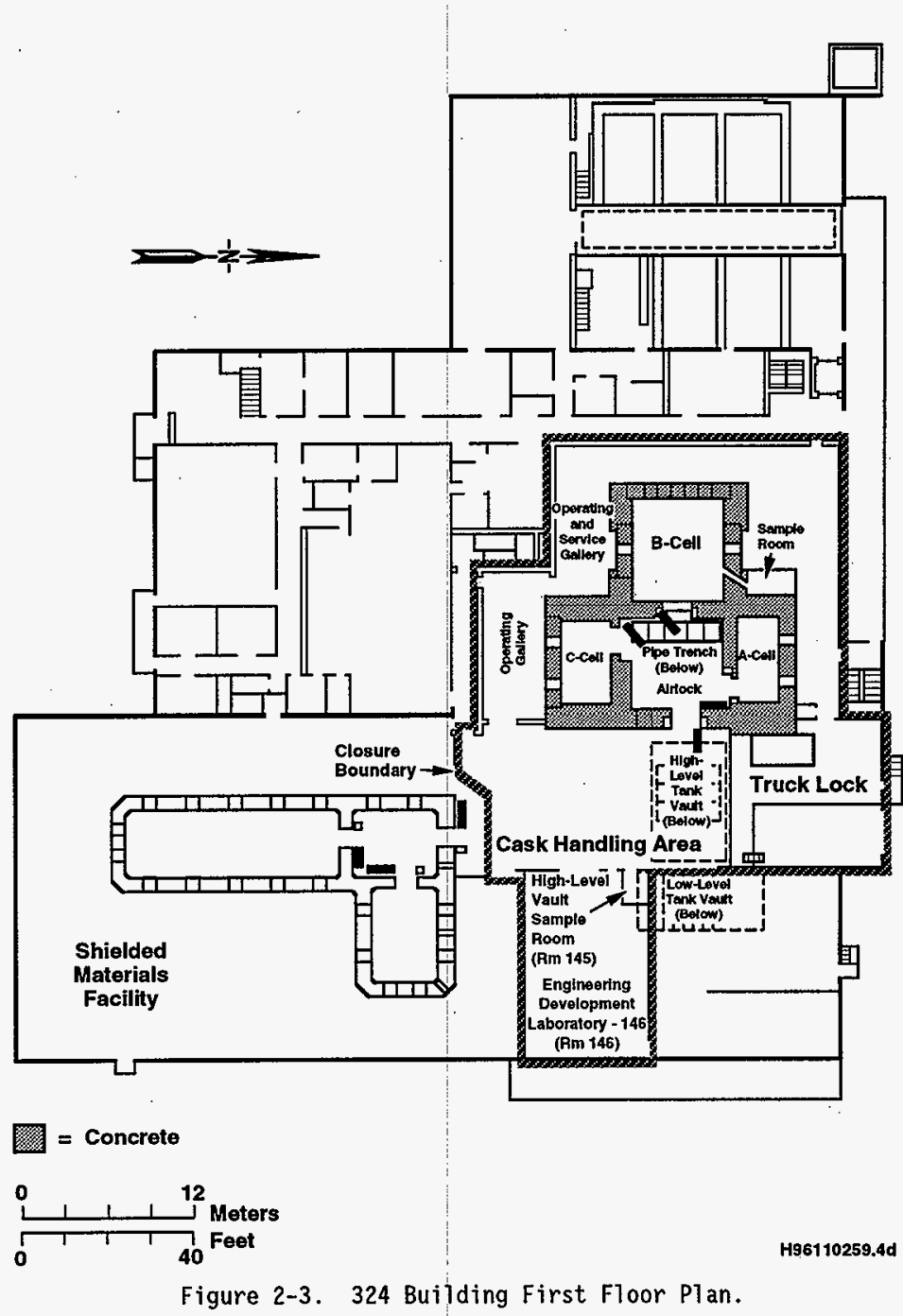




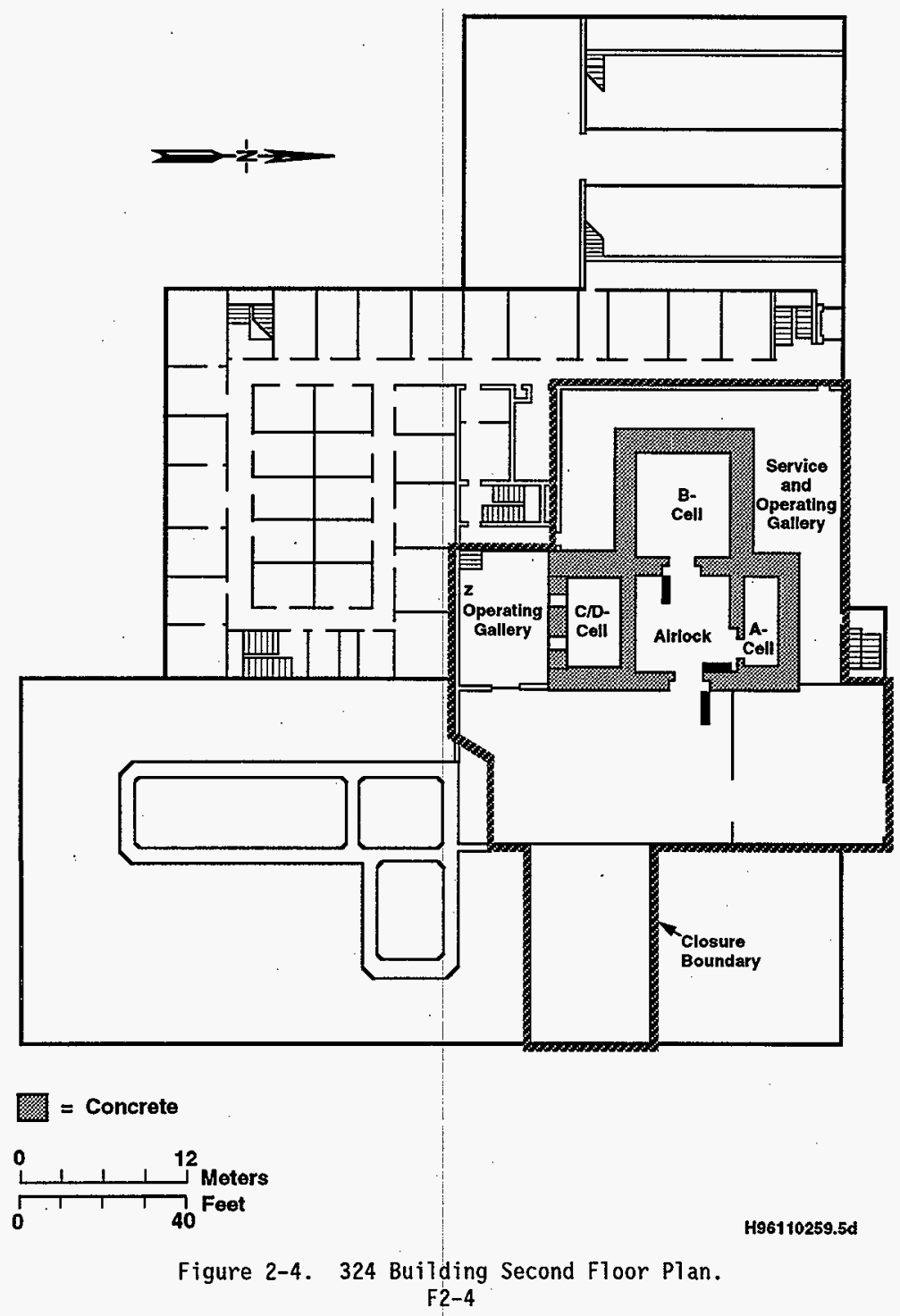




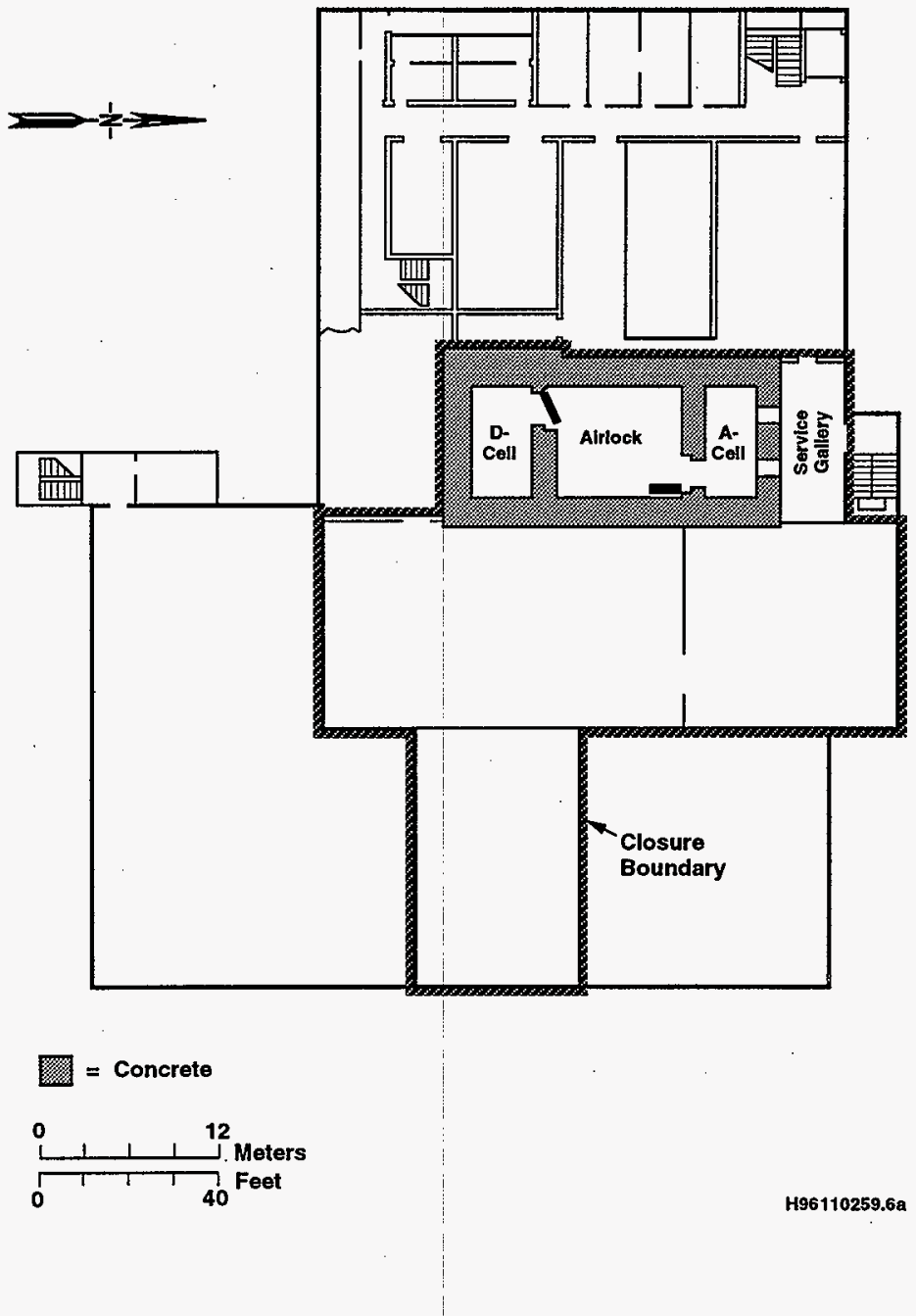

Figure 2-5. 324 Building Third Floor Plan. 


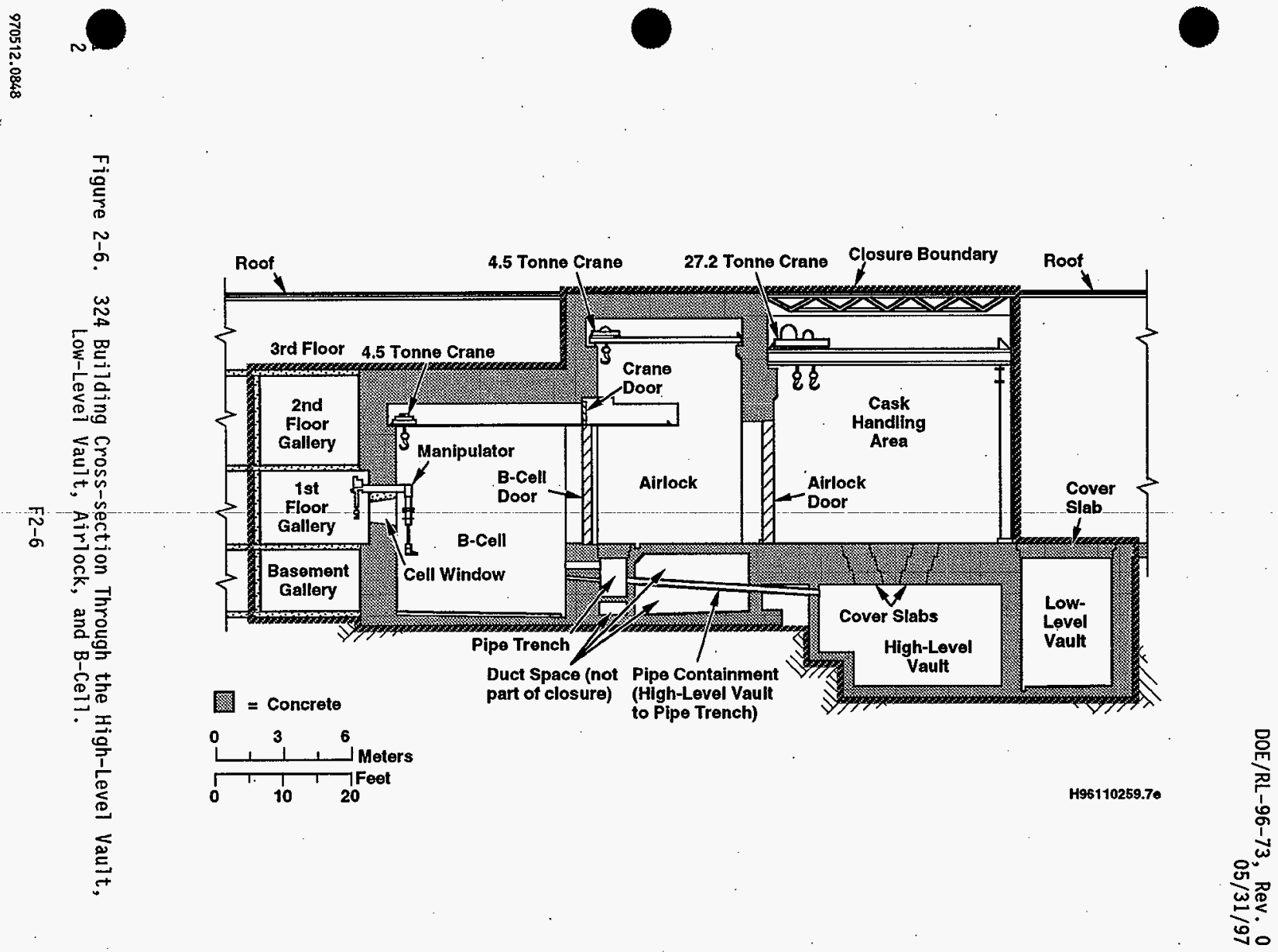




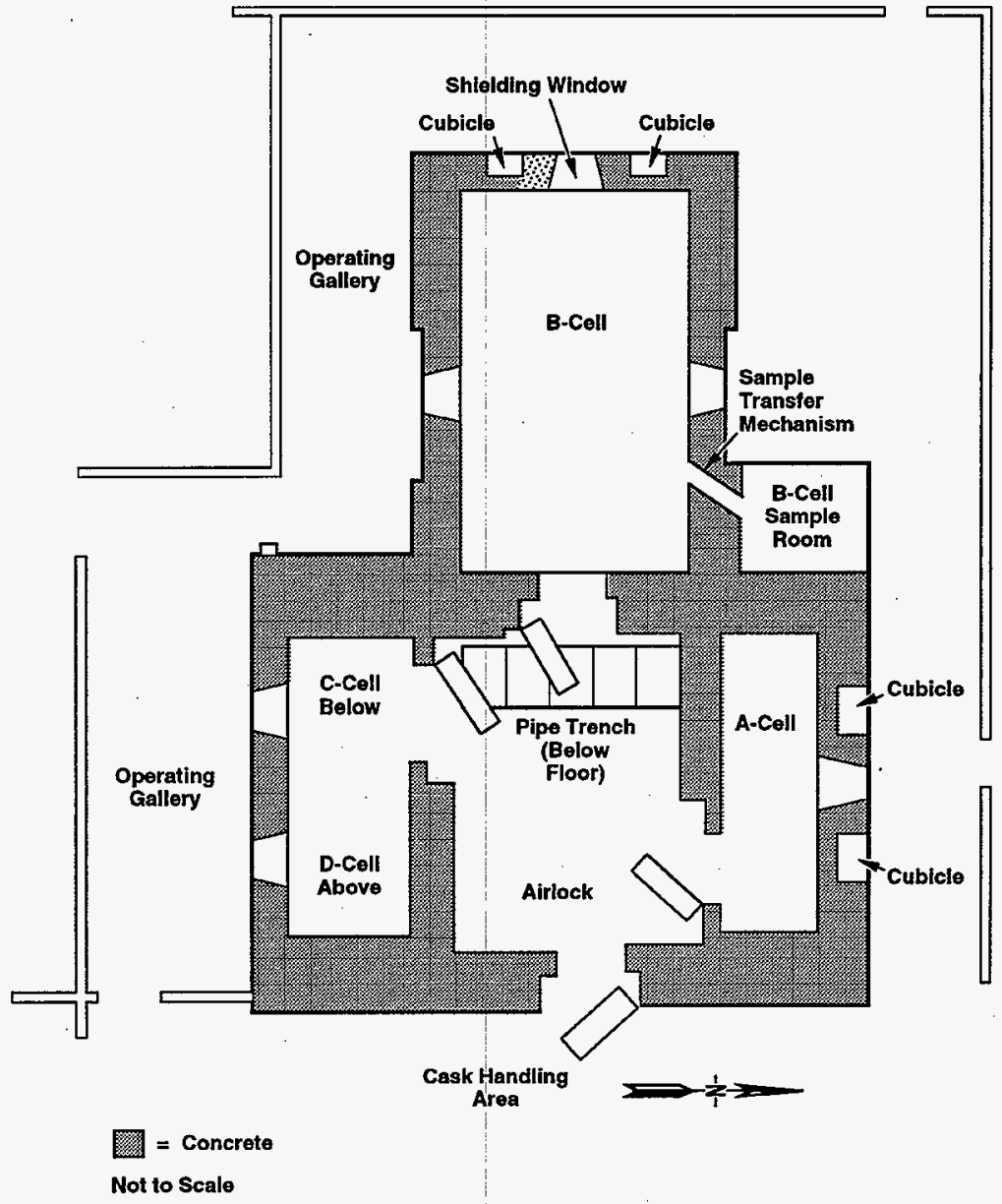

Note: Hot cell and airlock doors are interlocked.

Airlock cannot be accessed whon any hot cell door is open.

Figure 2-7. Overall Planning for 324 Building Radiochemical Engineering Cel1s. 


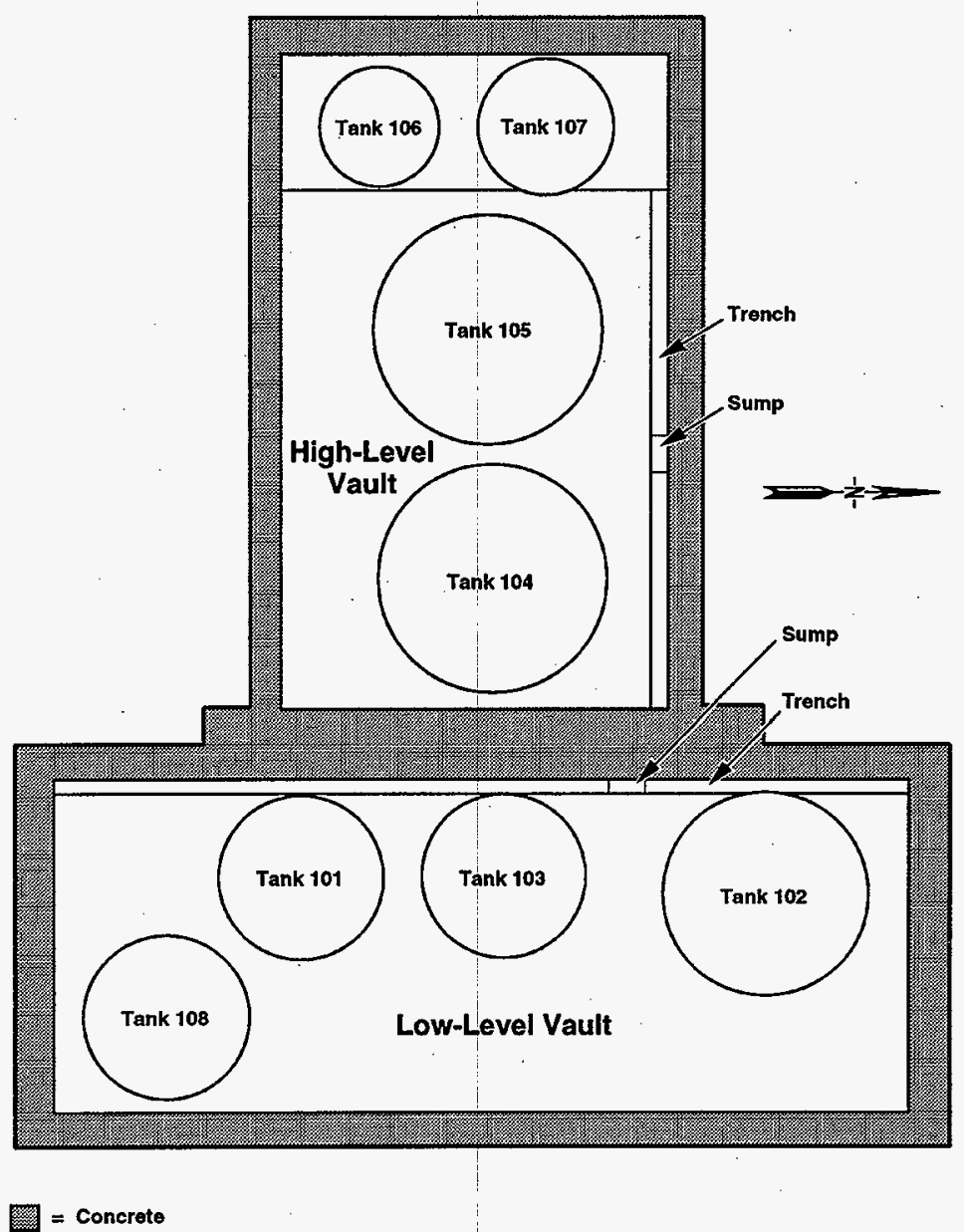

Not to Scale

H96110259.8d

Figure 2-8. 324 Building High-Level Vault, Low-Level Vault, and Vault Tanks. Piping omitted for clarity. 


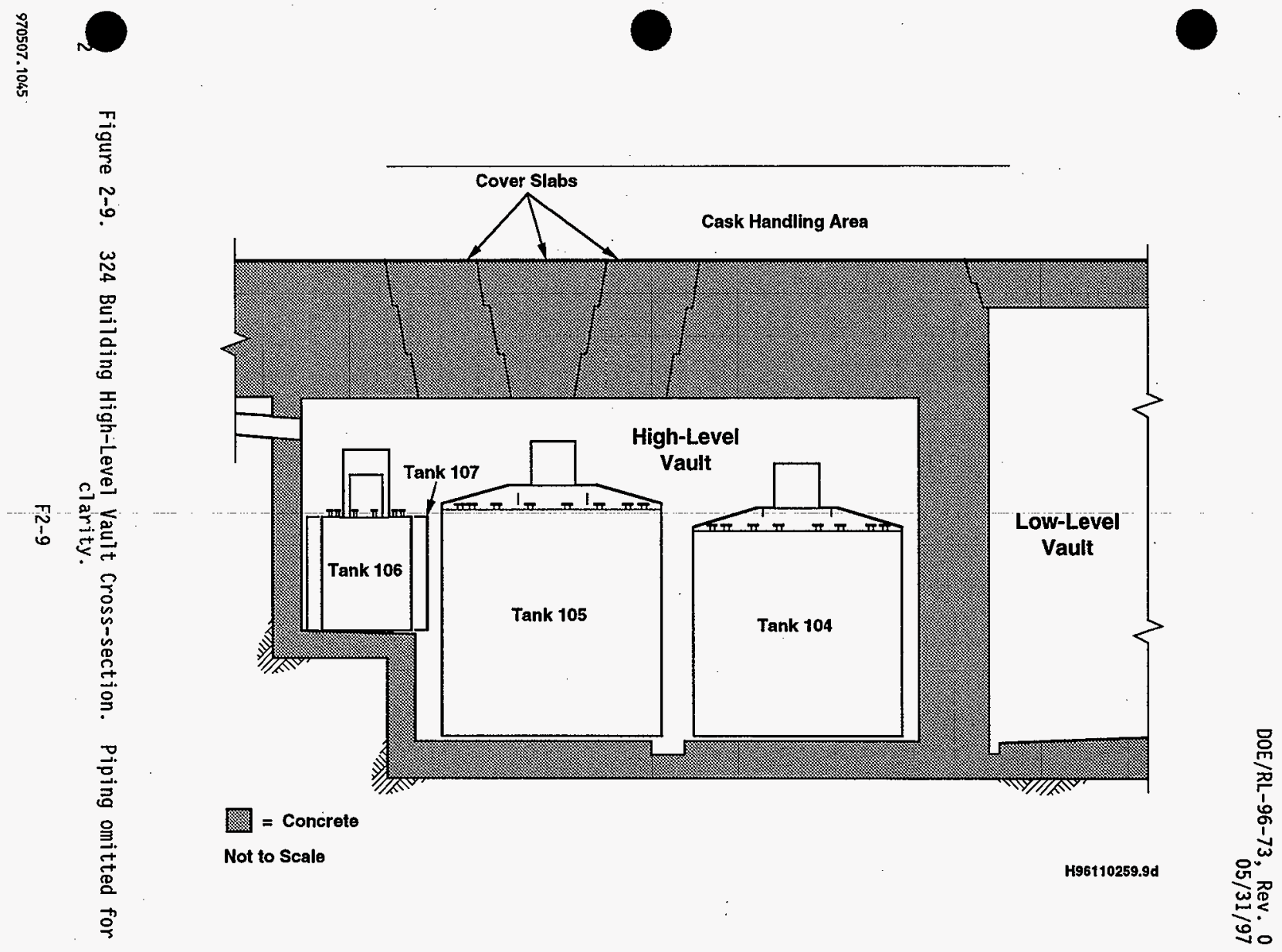


Figure 2-10. 324 Building High-Level Vautt Construction Photograph Before Sealing the Cover Blocks (10oking east at tanks 105 and 104). 


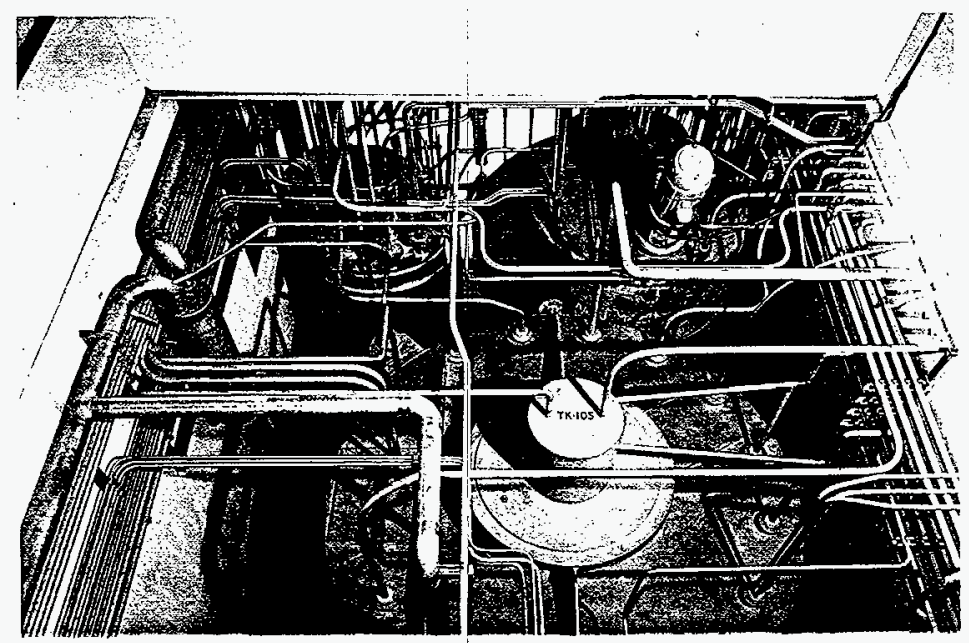

42179-6

(PHOTO TAKEN 1966)

Figure 2-11. 324 Building High-Level Vault Construction Photograph Before Sealing the Cover Blocks. Looking west at tanks 105 (center foreground), 107 (right rear), and 106 (left rear). 


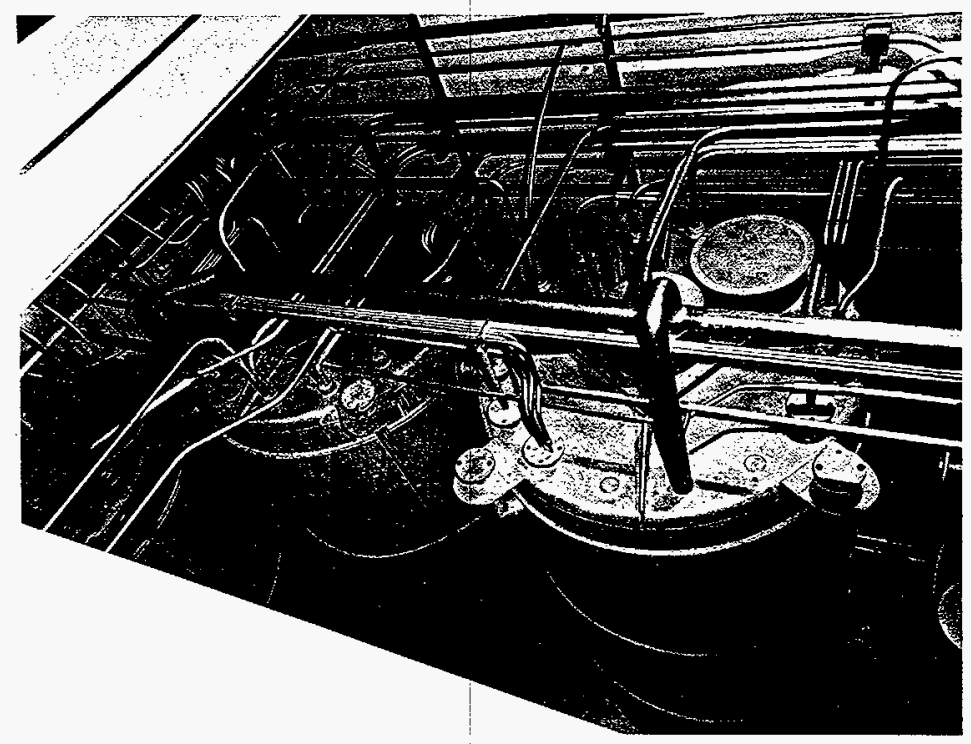

42179-2

(PHOTO TAKEN 1966)

Figure 2-12. 324 Building Low-Level Vault Construction Photograph Before Sealing the Cover Blocks. Looking east (left to right) at tanks 108, 101, and 103. 


\section{CONTENTS}

3.0 PROCESS INFORMATION .......................... 3- . . . .

3.1 WASTE PRODUCING PROCESSES . . . . . . . . . . . . 3-1

3.2 RADIOCHEMICAL ENGINEERING CELLS WASTE ACTIVITIES ..... . 3-1

3.2 .1 A-Cel] ......................... 3-2

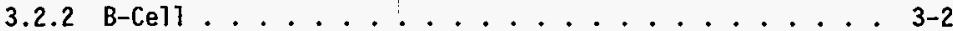

3.2 .3 C-Cel1 ....................... 3-4

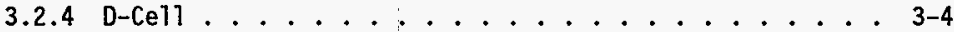

3.2 .5 Airlock .................... 3-5

3.2 .6 Pipe Trench ............... . . 3-5

3.2.7 Other Components . . . . . . . . . 3-5

3.3 HIGH-LEVEL VAULT AND LOW-LEVEL VAULT WASTE ACTIVITIES . . . . 3-6

3.3 .1 High-Level Vaułt .................. 3-6

3.3.2 Low-Level Vault . . . . . . . . . 3-8

3.3.3 High-Level Vault Sample Room (Room 145) ...... 3-9

3.4324 BUILDING PIPING SYSTEM $\ldots \ldots \ldots \ldots$

3.5 OTHER 324 BUILDING AREAS ............... . . . . . . . .

3.5.1 Cask Handling Area . . . . . . . . . . . . . . . 3-10

3.5.2 Trucklock ................... 3-11

3.5.3 Engineering Development Laboratory-146 (Room 146 . . . 3-11

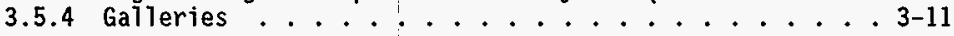


3-1 Schematic of the 324 Building High-Level Vault Process Piping for Tank 104 . $\dot{0} \dot{3} \dot{4}$ Building High-iel vault Process Piping for

3-2 Schematic of the 324 Building High-Level Vault Process Piping for

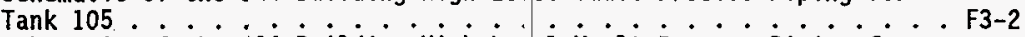

3-3 Schematic of the 324 Building High-Level Vault Process Piping for

3-4 Schematic of the 324 Building High-Level Vault Process Piping for 106 F3-3 Tank 107 . . . . . . . . . . . . F3-4

3-5 Schematic of the 324 Building Low-Level Vault Process Piping for Tank $101 \ldots \ldots \ldots \ldots$. . . . . . . . F3-5

3-6 Schematic of the 324 Building Low-Level Vault Process Piping for Tank $102 \ldots \ldots$. . . . . . . . . . . . . . . .

3-7 Schematic of the 324 Building Low-Leve Vault Process Piping for Tank $103 \ldots \ldots$. . . . . . . . . F3-7

3-8 Schematic of the 324 Building Low-Level Vault Process Piping for F3-1 Tank 108 F3-8 


\subsection{PROCESS INFORMATION}

Process information for all the areas included in the closure boundary is presented in this chapter. A general description of the projects that have generated the waste in the 324 Building REC, HLV, and LLV is presented. Also, a description of waste producing processes and how the processes have affected each of the areas included in the closure boundary is provided. This process information is used to determine the specific portions of the 324 Building that require closure activities. The closure activities for these portions of the 324 Building are described in Chapter 7.0.

\subsection{WASTE PRODUCING PROCESSES}

The following three programs have generated the liquid waste in B-Cell and HLV:

- Waste Solidification Engineering Prototype Program (WSEP)

- Nuclear Waste Vitrification Project (NWVP)

- Fabrication of Cesium and Strontium Heat and Radiation Sources, known as the Federal Republic of Germany (FRG) Program.

The FRG Program was part of the pilot scale radioactive liquid-fed ceramic melter (RLFCM) testing task. Only the FRG Program generated mixed waste. The Zeolite Vitrification Demonstration Project (ZVDP) also was conducted in B-Ce11, but the program handled only solid waste and did not use the HLV or LLV. More information on the WSEP, NWVP, FRG Program, and the ZVDP is included in the discussion of B-Cell waste activities (Section 3.2.2). Since 1987, no major programs have generated 7iquid waste for the HLV or LIV tanks. The HLV tanks were flushed and rinsed in 1996 and have not been utilized since.

\subsection{RADIOCHEMICAL ENGINEERING CELLS WASTE ACTIVITIES}

Since 1968, 1iquid waste generated within the REC has been discharged at various times to the HLV and LLV. The waste consisted of solutions generated during research and development (R\&D) activities and solutions from

radiological decontamination activities. Solutions have been transferred via piping between various tanks in the HLV and LLV and the REC cells. Solutions from the LLV can be discharged to the 340 Building. The piping system has been designed so that, while solutions can be transferred from the LLV to the HLV, solutions cannot be transferred directly from the HLV to the LLV. 


\subsection{A-Cel1}

A-Cell was cleaned and refurbished in 1987 before the installation of the FRG Program electropolisher and water-cooled storage rack. Dangerous waste producing activities included the generation of electropolisher waste in October 1988 as part of the FRG Program. This waste material, phosphoric acid with chromium, was transferred to tank 102 in the LLV, where the waste was neutralized and transferred to the 340 Building. A-Cell tanks functioned as less-than-90-day storage areas. Other, mole recent, dangerous waste activities included the establishment of a less-than-90-day storage area in A-Cell for electropolisher (phosphoric acidl) waste. This waste was containerized and transferred to the Centrall Waste Complex (CWC). A-Cell currentiy stores 34 isotopic heat sources in canisters (Section 3.2.2.4).

Because A-Cell did not treat or store dangerous waste, except as a lessthan-90-day storage area, no closure activities will be performed in A-Cel1.

\subsubsection{B-Cell}

Since the late 1960 's, B-Cell has beer used to demonstrate chemical engineering pilot-scale processes for radicactive waste management programs. These programs left $\mathrm{B}-\mathrm{Ce} 11$ filled with equipment that is highly contaminated with radioactive waste, radioactive materials, and materials that have been designated as mixed waste. Additionally, B-Cell contains dispersible (i.e., easily spreadable) radioactive material that must be placed in containers and removed to minimize the risk of significant human and environmental effects in the event of a major accident.

The majority of waste producing activities of concern for closure occurred in B-Cell. The B-Cell activities are summarized as follows:

\begin{tabular}{l|l}
\multicolumn{1}{c|}{ Activity } & \multicolumn{1}{c}{ Dates } \\
\hline WSEP & $1966-1972$ \\
No Activity & $1972-1976$ \\
NWVP & $1976-1979$ \\
No Activity & $1979-1981$ \\
ZVDP & 1981 \\
Pilot-Scale RLFCM testing task (includes & $1982-1987$ \\
the FRG Program between 1986 and 1987) & \\
No Activity & $1987-1988$ \\
B-Cell Safety Cleanout Project (BCCP) & $1988-$ present.
\end{tabular}


B-Cell was used to manage mixed waste, therefore, closure activities are required. The dangerous and mixed waste that were generated in $\mathrm{B}-\mathrm{Ce} 11$ are described in Chapter 4,0.

3.2.2.1 Waste Solidification Engineering Prototypes. The WSEP was the first program to be performed in B-Cel1. The WSEP program began in 1966 and continued through 1972. The program was designed to demonstrate methods of solidifying highly radioactive waste.

The feed-material compositions used in the WSEP program were prepared to represent (1) a plutonium-uranium extraction (PUREX) process waste solution that contained a large amount of iron such as would result when an iron canister is used to transfer nuclear fuel elements and the canister was co-dissolved with the nuclear fuel and (2) a PUREX process waste solution optimized to produce a waste containing a minimum quantity of nonfission product material. Several elemental substitutions were made for the fission products. Elements present in the WSEP feed included molybdenum, nickel, cobalt, copper, potassium, rubidium, iron, and aluminum.

3.2.2.2 Nuclear Waste Vitrification Project. The NWVP provided a demonstration of the vitrification of highly radioactive liquid waste from spent nuclear fuel that was discharged from an operating light water reactor. The NWVP started in 1976 and was completed in 1979.

Commercial spent nuclear fuel was brought into B-Ce11. The spent nuclear fuel was dissolved and transferred to the 325 Building for processing. The solution was returned to $\mathrm{B}-\mathrm{Ce} 11$ where the solution was incorporated into melter feed and vitrified (turned intolglass logs). Two glass logs were produced. These logs have been moved to the PUREX storage tunnels (Ecology 1996). The waste produced during this project was stored in HLV tank 107 .

3.2.2.3 Zeolite Vitrification Demonstration Project. The ZVDP was a process for decontaminating highly radioactive water. The ZVDP was started and completed in 1981 .

The process used beds of zeolite to sorb strontium and cesium from the solutions. The project was responsible for demonstrating the full-scale vitrification of the zeolite material. The project used a process where the dry zeolite was mixed with dry glass formers and fed to a canister inside an in-can melter. The zeolite was vitrified. The zeolite has been moved to the PUREX storage tunnels (Ecology 1996).

3.2.2.4 Pilot Scale Radioactive Liquid-Fed Ceramic Melter Testing Task and the Fabrication of Cesium and Strontium Heat and Radiation Sources. The RLFCM testing task ran from 1982 to 1987. Installation and testing of the ceramic melter in B-Cell occurred between 1982 and 1986. Part of this testing task was the fabrication of cesium and strontium heat and radiation sources (the FRG Program). The FRG Program produced 34 isotopic heat sources in canisters as part of a repository testing program. The FRG Program started in 1986 and was completed in 1987 . 


\subsubsection{C-Cell}

C-Cell was cleaned in 1989. Since 1989, C-Cell has been used for R\&D activities. C-Cell also has been used to temporarily (less than 90 days) store mixed waste.

Because C-Cell did not treat or store dangerous waste, except as a lessthan-90-day storage area, no closure activities will be performed in C-Cel1.

\subsubsection{D-Cell}

Current and past activities conducted in D-Ce11 have been in support of commercial spent nuclear fuel projects. These projects have included nuclear fuel sampling and the development and testing of radioactive-glass waste forms. 
D-Cell had been used to store a 208-1iter container of mixed waste containing absorbed waste mineral oil from July 1994 until January 1996. This waste was generated in B-Cell by a window leak. The container was removed from D-Cell in January 1996. A portion of D-Cell has been used for storage of HLV 1iquid waste treatment equipment (Section 3.3.1.5). The waste treatment equipment is being stored in D-Cell until a determination is made that there is no further need for the equipment. The HLV liquid waste treatment involved transferring the waste and rinsates from the HLV tanks to D-Cell via tank 112 in $\mathrm{B}-\mathrm{Ce}$ 11. The material was neutralized and chemicals added to precipitate the strontium for recovery. Ion exchange was used for cesium recovery. Filters contaminated with heavy metals from this treatment process are being stored temporarily in D-Ce11. These filters will be transferred to $\mathrm{B}-\mathrm{Ce} 11$ as soon as practical and will be disposed of along with the dispersible material in $\mathrm{B}-\mathrm{Cell}$. These filters are considered a mixed waste.

Because areas of D-Cell were used to store the waste mineral oil, which was classified as a mixed waste, for longer than 90 days and to treat waste from the HLV, closure activities will be performed on those portions of. D-Cel1.

\subsubsection{Airlock}

The airlock allows for access to the four RECs (A-Cell, B-Cell, C-Cell, and D-Cel1) and the pipe trench. The airlock is used primarily as a transition zone for maintenance, decontamination, and transfer of material and equipment into and out of adjoining RECs. The airlock has been used for radiological decontaminations with the decontamination solutions being sent to $\mathrm{B}-\mathrm{Ce} 11$, the HLV, or the LLV as appropriate. The airlock will be isolated from the HLV.

\subsubsection{Pipe Trench}

The pipe trench was used to make utility, process, and waste handling piping connections between the cells and the HLV. Process and waste handing piping runs between the pipe trench and the HLV, LLV, and B-Cell. The pipe trench will be isolated from the HLV.

\subsubsection{Other Components} cubicles.

Other areas of concern to the closure are the pass-through ports and the

3.2.7.1 Pass-through Ports. The pass-through ports were used to support cell operations. No specific waste generation or waste handling were specifically associated with the ports. The ports will not require closure activities.

3.2.7.2 Cell Cubicles. The A-Cel1 cubicles (A-11, A-12, A-21, A-22, A-31, $A-32)$ and $B-C e 11$ cubicles $(B-12$ and $B-14)$ were used to make process 


\subsubsection{High-Level Vault}

The four HLV tanks have been used to store process materials and waste from various locations in the 324 Building including the REC. Before the HLV liquid waste treatment project, some of these tanks stored waste materials. The HLV liquid waste treatment project drained and flushed the tanks in 1996.

3.3.1.1 Tank 104. Tank 104 can receive scilution from C-Ce11, D-Ce11, A-Cel1 cubicles $A-11$ and $A-12, B-C e 11$ cubicles B-12 and B-14, the LOS; HLV sump; and HLV tanks 105 and 107 and LLV tank 102. The contents of tank 104 can be transferred to the LOS and tank 105. There also are process connections to and from tank 104 and the pipe trench (Figure 3-1).

Cesium nitrate solution generated during the FRG Program was stored in tank 104. Since 1988, the only transfers that occurred were from tank 104 to tank 105. On May 7 and 8, 1991, partial transfers were made to tank 105. On September 25, 1992, periodic additions of water to tank 104 were begun to replace water lost to evaporation. This material initially was considered a product material in storage in tank 104. However, on April 20, 1994, the DOE-RL determined that there is no future use for the material and reclassified the material as mixed waste. Tank 104 was flushed and drained in 1996.

3.3.1.2 Tank 105. Tank 105 can receive solution from tanks 104 and 106 , A-Ce11 cubicles A-11 and A-12, B-Cel1 cubicles B-12 and B-14, the LOS, and the airlock. The contents of tank 105 can be transferred to tank 104 and the LOS. There also are process connections to and from tank 105 and the pipe trench (Figure 3-2).

Strontium nitrate/cesium nitrate solution from the FRG Program canister fabrication project was stored in tank 105. Since 1988, the only transfers that occurred to tank 105 were from tank 104. On May 7 and 8, 1991, partial 
transfers were made from tank 104. On September 25, 1992, periodic additions of water to tank 105 were begun to replace water lost to evaporation. This solution initially was considered a product material in storage and was stored in tank 105. However, on Apri] 20, 1994, the DOE-RL determined that there was no future use for the material and reclassified the material as mixed waste. Tank 105 was flushed and drained in 1996.

3.3.1.3 Tank 106. Tank 106 can receive solution from tank 107 , the $L O S$, B-Ce11 cubicles B-12 and B-14, and D-Cell. The contents of tank 106 can be transferred to the L.OS and tanks 105 and 107 . There are process connections between tank 106 and the pipe trench (Figure 3-3).

Tank 106 had been used to receive NWVP feed from the 325 Building via. a connection in the pipe trench. The NWVP feed was transferred to tank 107 for transfer to the RECs. Tank 106 was rinsed in 1990 and sampling results indicated that the tank contained no RCRA waste. There are no dangerous waste activities on record. There are no recorded transfers into or out of this tank since October 1988. Tank 106 was flushed and drained in 1996.

3.3.1.4 Tank 107. Tank 107 can receive solution from tank 106 and from a chemical addition line. The contents of tank 107 can be transferred to the LOS and tanks 104 and 106 . Tank 107 can also receive and transfer to the pipe trench (Figure 3-4).

High-level waste material that was used as feed material for the NWVP was stored in tank 107. Nitric acid was added to tank 107 on January 31, 1989, May 19, 1989, and November 10, 1989. In January 1990, the solution and subsequent rinse water was transferred to tank 112 in $\mathrm{B}-\mathrm{Ce} 11$ via a connection in the pipe trench. Tank 112 is a supplementary tank located in B-Cell. The material was transferred to tank 112 as the first step in a potential disposal process. It was later determined not to use that disposal process and the material and rinse water was returned to tank 107 in November 1992. On March 2, 1993, periodic additions of water to tank 107 were begun to replace water lost to evaporation. The material initially was considered a product material in storage. However, on Apri1 20, 1994, the DOE-RL determined that there was no future use for the material and reclassified the material as mixed waste. Tank 107 was flushed and drained in 1996.

\section{3:1.5 High-Level Vault Waste Removal Activities}

To comply with Tri-Party Agreement Milestone M-89-01, the waste stored in the HLV was removed and the HLV tanks were rinsed and flushed in September 1996. The HLV tanks initially were decontaminated using a flushing and rinsing method. The waste in the tanks was transferred to tank 104 in the HLV. From tank 104, the waste was steam jetted to tank 112 in B-Cell, and vacuum transferred to the waste treatment system in D-Cell. The solutions were adjusted chemically to precipitate the metals and the precipitates were collected on filters. The remaining liquid underwent a carbonate

precipitation to remove the strontium-90 which was collected for use in the 
medical isotope program. The liquid was passed through an ion exchange column to collect the cesium-137. The remaining low-level liquid was transferred to the 340 Building for subsequent transfer to the DST system.

The HLV tanks were sequentially triple rinsed; the rinse solutions were jetted through each tank and transferred to D-Cell for treatment. The first two rinses were dilute nitric acid, the third was a dilute carbonate rinse.

\subsubsection{Low-Level Vault}

The four LLV tanks are used as waste iccumulation or transfer vessels for process waste from the REC and other generation activities. The tanks are used to send waste to the DST System in the 200 Areas by way of the 340 Building.

3.3.2.1 Tank 101. Tank 101 can receive solution from tanks 103 and 108; tank 115 with in B-Ce11; the LOS, the process drains in cubicles A-11, A-12, $B-12$, and $B-14$, the cubicle drains in cubicles $A-11, A-12, A-21, A-22, A-31$, $A-32, B-12$, and $B-14$; the pipe trench, the sampler drain in the sample room; and the Room 11 drain. The contents of tark 101 can be transferred to tank 102 or to the 340 Building (Figure 3-5i).

Tank 101 was used to receive condensate from the fractionator distillate receiver in $\mathrm{B}-\mathrm{Cell}$. The fractionator distillate condenses vapors coming from the melters. The only transfers that have occurred to tank 101 were from C-Ce11 and airlock decontamination solutions that were transferred to tank 101 from tank 103 in October 1989.

The solution that was present in tank 101 in June 1990 was analyzed and determined to be nonhazardous. In 1990, taink 101 contained 5,300 1iters. Between 1990 and 1996, the liquid evaporated; since mid-1996, the tank has been empty.

3.3.2.2 Tank 102. Tank 102 can receive scilution from tanks 101, 103, and 108; the LLV sump; cubicles A-11, A-12, B-12, and B-14; C-Ce11; D-Cel1; and the EDL safety showers. The contents of tank 102 can be transferred to HLV tank 104, the LOS, or to the 340 Building (Figure 3-6).

Tank 102 was used to receive condensate from the fractionator distillate receiver in $\mathrm{B}-\mathrm{Ce} 11$ via a connection in the pipe trench. Tank 102 also was used to collect solution from the header ir: Rooms 146 and 147 and the trucklock sump.

In October 1988, tank 102 received a phosphoric acid solution from A-Cell. The material was neutralized and transferred to the 340 Building. In January 1989, tank 102 received solution from tank 103 and the solution was transferred to the 340 Building. In November 1990, tank 102 received a nonhazardous solution from tank 103 and the solution was transferred to the 
340 Building. In May 1991, tank 102 received a nitric acid solution containing chromium from tank 108. The solution was neutralized with sodium hydroxide and transferred to the 340 Building in May 1991.

The solution present in tank 102 in June 1990 was designated as mixed waste and remained in the tank until November 1990 when the mixed waste was transferred to the 340 Building. Tank 102 is currently empty.

3.3.2.3 Tank 103. Tank 103 received solution from the LOS. The contents of tank 103 can be transferred to tanks 101 and 102, and the LOS. There is a pipe between tank 103 and the pipe trench (Figure 3-7).

Tank 103 was used to receive radiological decontamination solutions from $\mathrm{C}-\mathrm{Ce}] 1$ and the airlock via a connection in the pipe trench. No dangerous waste activities took place in tank 103. The solution in tank 103 was sampled and analyzed in June 1990 and mistakenly was designated as mixed waste. However, review of the 1990 data has indicated that the solution was a nondangerous waste.

In November and December 1988, tank 103 received C-Cell and airlock decontamination water. In January 1989, the contents of tank 103 were transferred to tank 102 and then to the 340 Building. In January and February 1989, tank 103 received C-Cell and airlock decontamination water. In October 1989, the solution was transferred to tank 101. In November 1990, the contents of tank 103 were transferred to tank 102. Tank 103 -js empty.

3.3.2.4 Tank 108. Tank 108 can receive solution from the EDL-146 drains and the pipe trench. The contents of tank 108 were transferred to tanks 101 and 102. There is a process connection from the pipe trench to tank 108 (Figure 3-8).

During FRG Program canister fabrication, tank 108 was used to receive nitric acid from the acid fractionator in B-Cell via a connection in the pipe trench. The solution in tank 108 was sampled and analyzed in June 1990 and was designated as mixed waste. The mixed waste remained in tank 108 until May 1991 when the mixed waste was transferred to tank 102 . Tank 108 is currently empty.

\subsubsection{High-Level Vauit Sampie Room (Room 145)}

Inside the sample room is a containment box that has vacuum sampling lines to the LLV and HLV tanks. The room was last used in 1990 to sample all of the tanks. Vacuum sampling is not the preferred option for the HLV because operations personnel are exposed to a significant radiation dose during sampling activities. Because of the high radiation associated with the material, any drips or leaks that might have occurred inside the containment box would have been cleaned up immediately.

As per agreement between Ecology and DOE (Ecology 1997), the closure activity required for the sample room is to isolate it from the vault tanks. 


\subsection{BUILDING PIPING SYSTEM}

Piping connected to the vault tanks serves a variety of functions, including process liquid transfer, chemical addition, waste transfer, instrumentation access, tank venting and sparging, cooling water supply and return, and sampling. Information on the process associated with the piping is given as part of the waste activities dilscussion for the REC (Section 3.2) and the HLV and LLV (Section 3.3).

\subsection{OTHER 324 BUILDING AREAS}

Four other areas of importance are within the closure boundary. These are the cask handling area, the trucklock, the EDL-146, and the galleries.

\subsubsection{Cask Handling Area}

The cask handling area is used for equipment and cask storage. No dangerous waste activities take place in the cask handling area; however, packaged waste does pass through the cask handling area as it exits the building.

Because the cask handling area did not. treat or store dangerous waste, no closure activities will be performed in this area.

\subsubsection{Trucklock}

The trucklock provides access into and out of the 324 Building for all radioactive material, except for liquid waste. The trucklock has contained a less-than-90-day storage area that periodically has been used as a staging area for contact-handled mixed waste. The trucklock also contained satelite accumulation areas that periodically were used to accumulate contact-handled mixed waste from the REC. All mixed waste brought into the trucklock area is packaged for radiological contamination control.

Because the trucklock did not treat or store dangerous waste, except as a less-than-90-day storage area and satellite accumulation area, no closure activities will be performed in the trucklock.

\subsubsection{Engineering Development Laboratory-146 (Room 146)}

The EDL-146 has been used for bench and pilot-scale process development activities. The EDL-146 has contained satellite accumuTation areas and lessthan-90-day storage areas. No waste has been stored in the EDL. Dedicated lines run between the EDL-146 and the LLV.

The Sodium Removal Pilot Plant, which is located within the EDL-146, is a RCRA permitted treatment facility currently undergoing Procedural Closure pursuant to the requirements of Tri-Party Agreement Section 6.3.3. The Sodium 
Removal Pilot Plant will not be addressed by this closure plan except that the 2 piping from the Sodium Removal Pilot PIant to the LLV will be isolated and 3 will undergo closure activities (See Chapter 7.0, Section 7.3).

Because the EDL-146 was not used to treat or store dangerous waste, except as a less-than-90-day storage area and satellite accumulation area, no closure activities will be performed in the EDL except for isolating the piping to the vault tanks.

\subsubsection{Galleries}

Galleries are radiologically controlled areas for use by personnel working with material in the RECs. The galleries include locations for operating remote manipulators that are connected to the cells, view ports into the cells, access to the cell cubicles, and pass-through ports from the REC.

The galleries are of concern for closure because of the pipes (steam lines, air lines, and chemical addition lines) that run from the second floor gallery into B-Cell and the HLV. The connections in the operating gallery allow for different combinations of air, steam, and chemicals to be used depending on the operations required in $\mathrm{B}-\mathrm{Ce} 17$ and the HLV.

The chemical addition lines were used during the HLV treatment process to add the chemical rinse solutions. No chemical residues are expected in these gravity flow lines. 
This page intentionally left blank. 


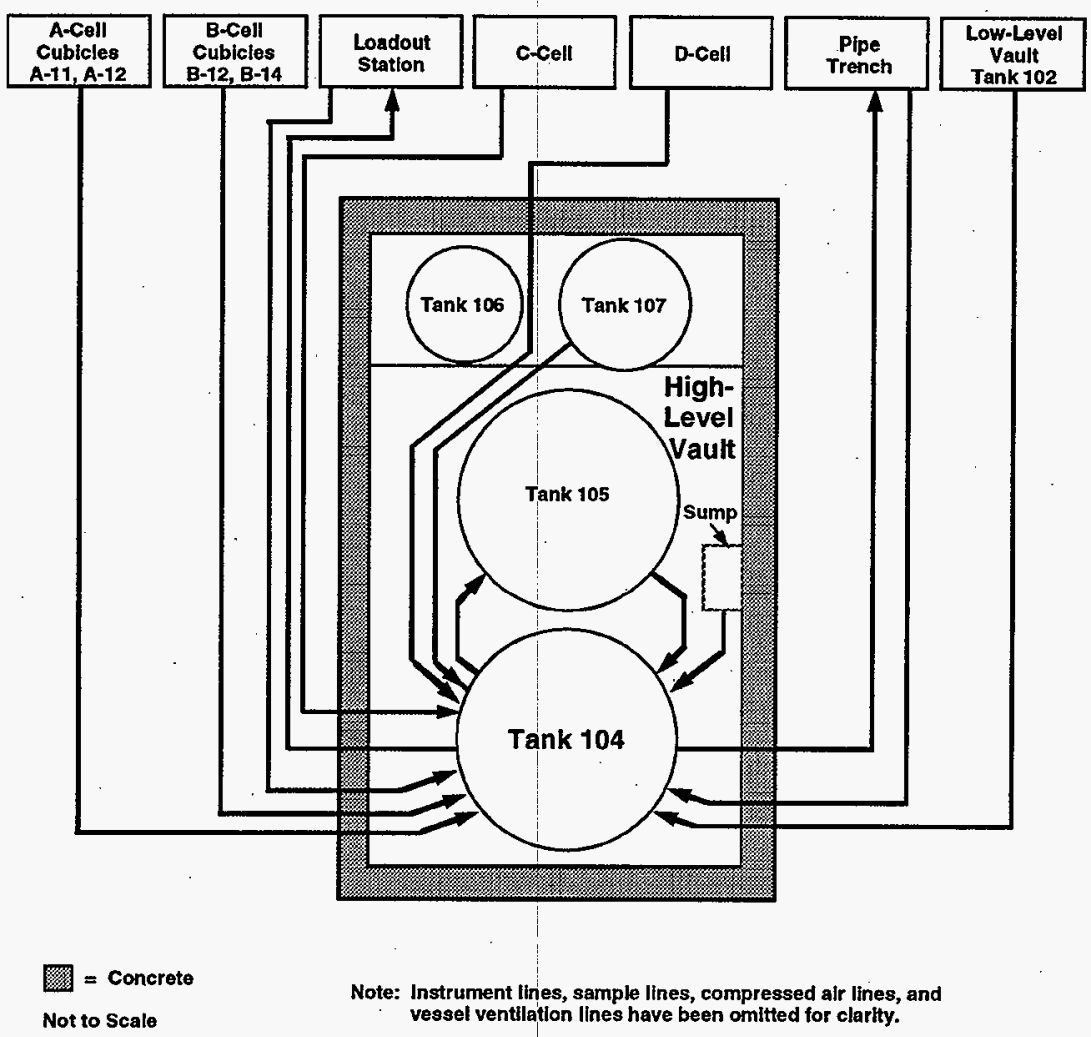

H96110259.1f

Figure 3-1. Schematic of the 324 Building High-Level Vault Process Piping for Tank 104. 


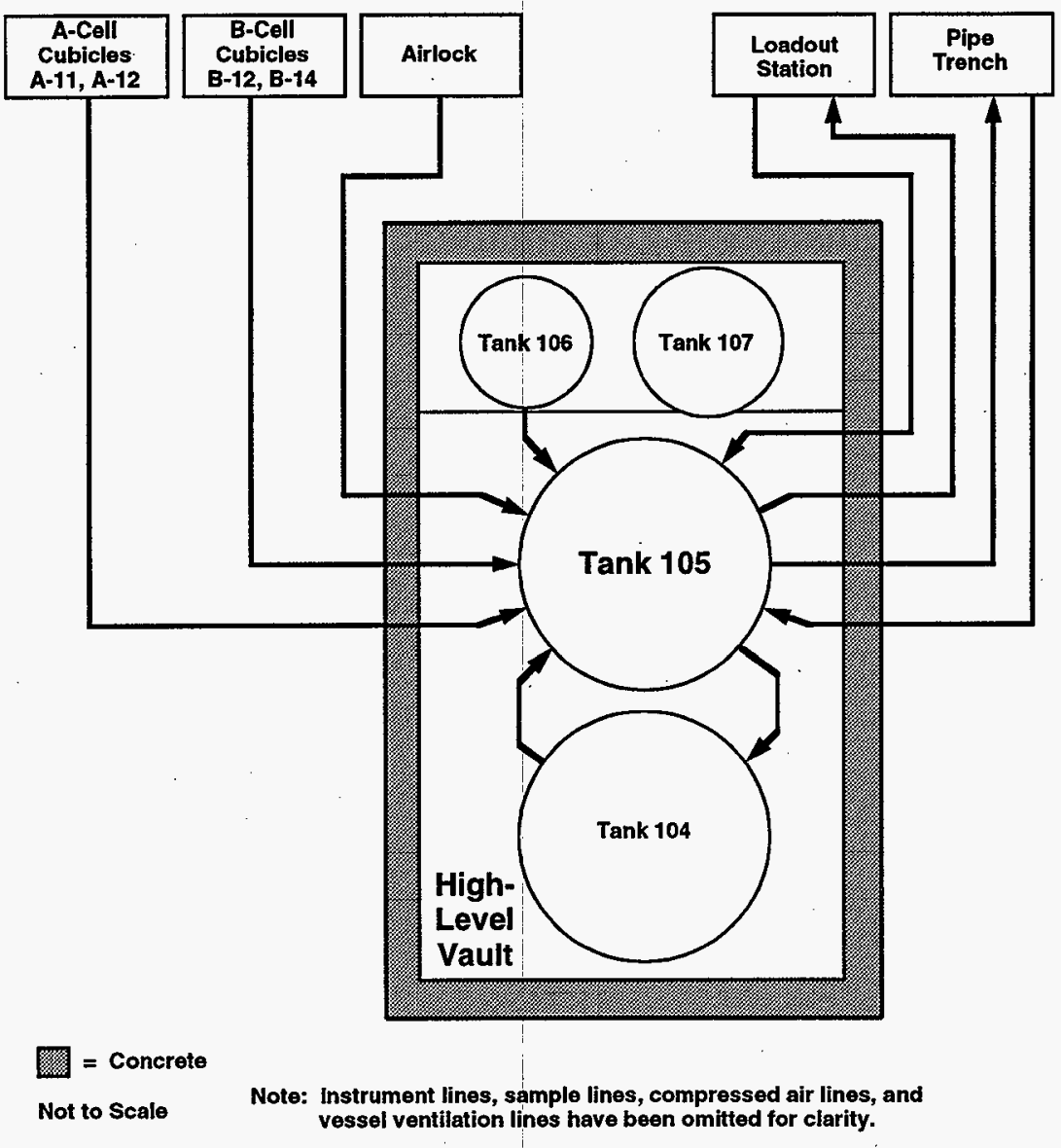

H96110259.13d

Figure 3-2. Schematic of the 324 Building High-Level Vault Process Piping for Tank 105. 


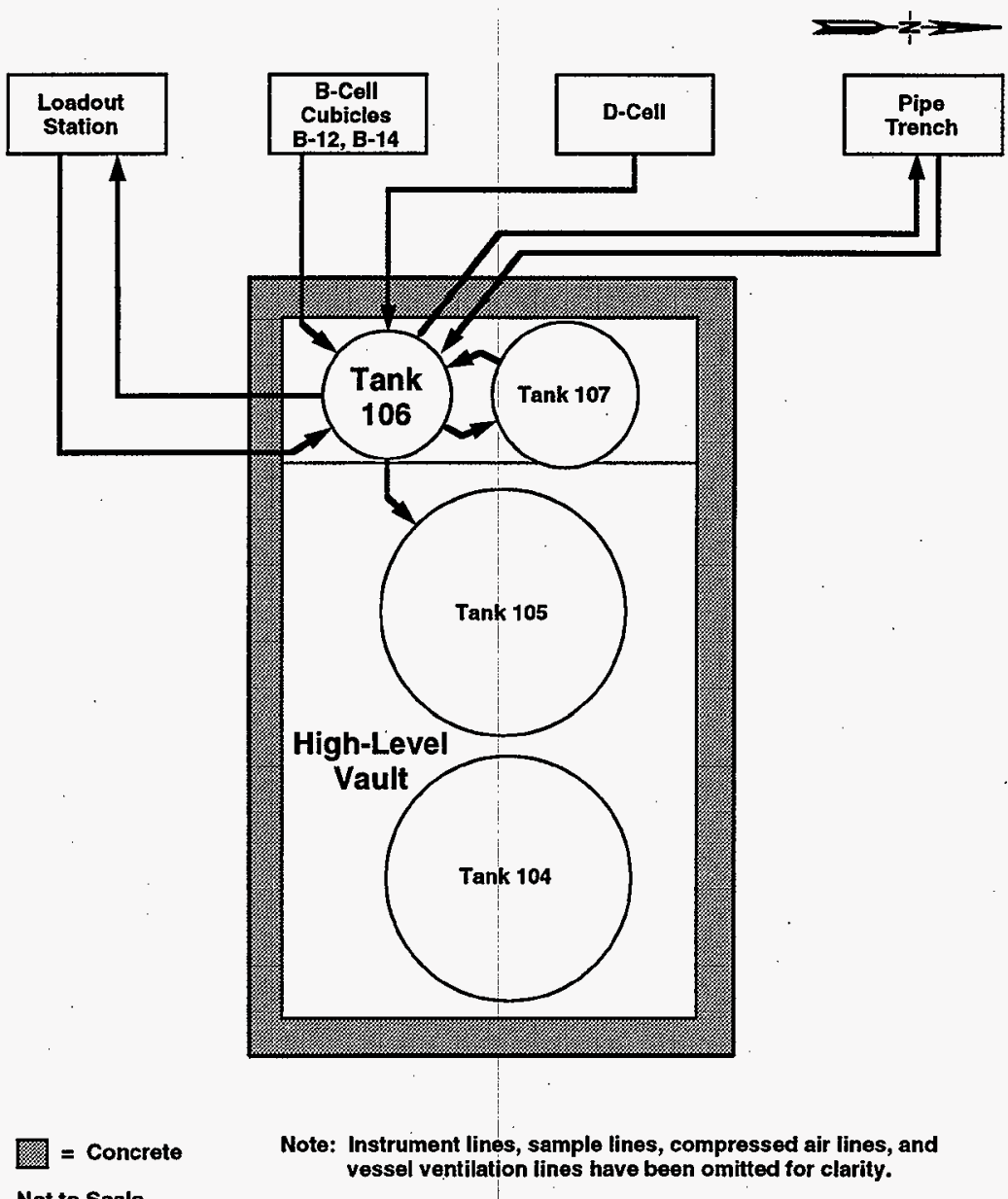

H961 10259.14d

Figure 3-3. Schematic of the 324 Building High-Level Vault Process Piping for Tank 106. 


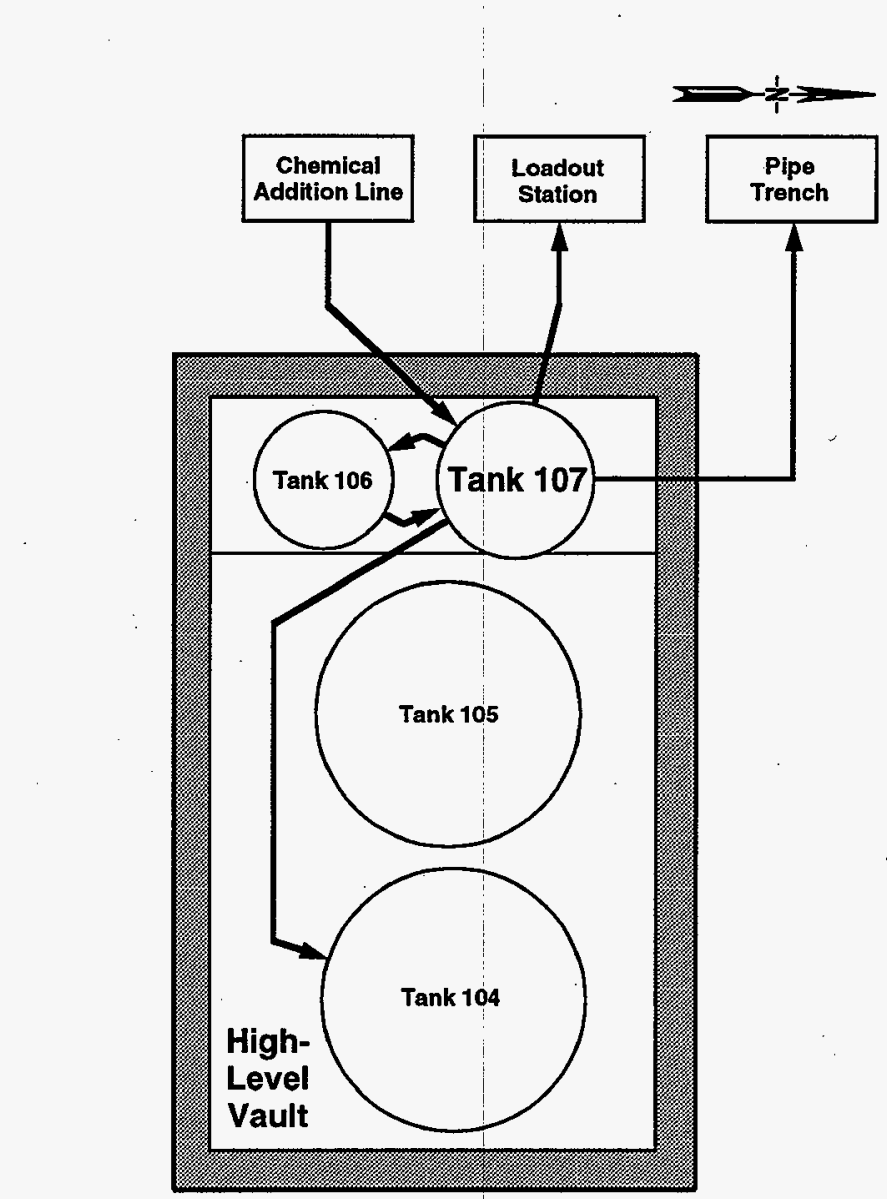

= Concrete

Note: Instrument lines, sample lines, compressed air lines, and Not to Scale vessel ventilation lines have been omitted for clarity.

H96110259.15d

Figure 3-4. Schematic of the 324 Building High-Level Vault Process Piping for Tank 107. 


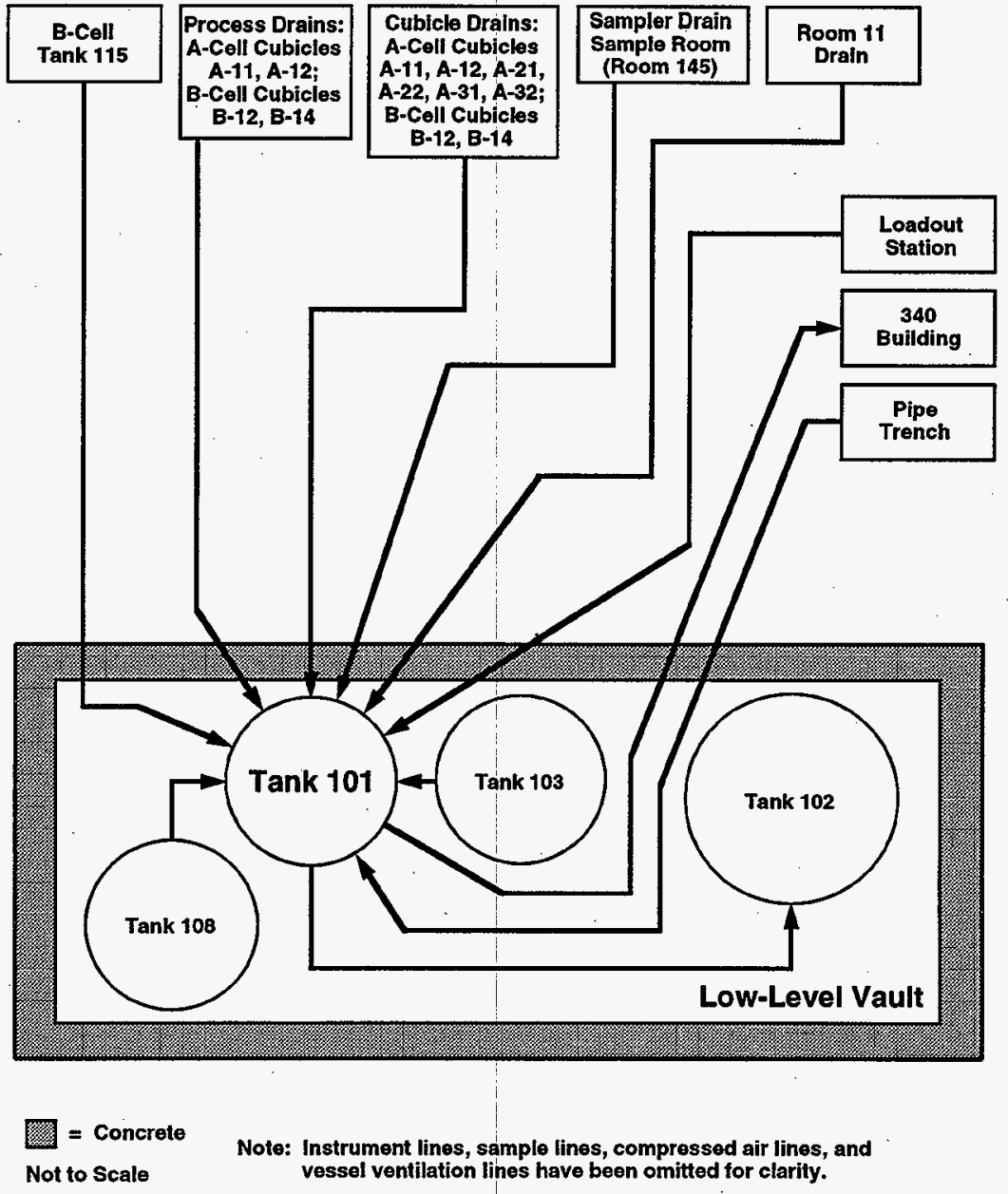

H96110259.16d

Figure 3-5. Schematic of the 324 Building Low-Level Vault Process Piping for Tank 101 . 


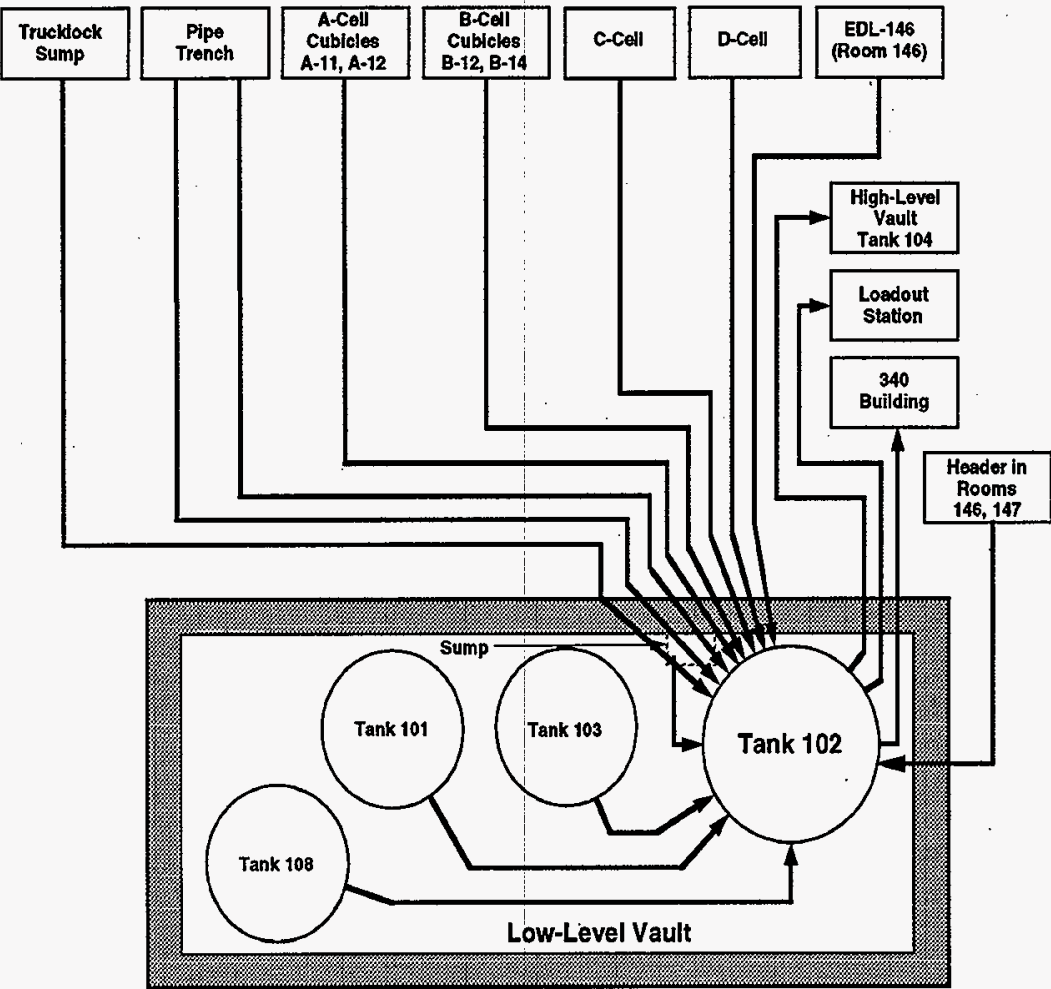

$\mathrm{EDL}=$ Engineering Development Laboratory

㓪 $=$ Concrete

Note: Instrument lines, sample lines, compressed air lines, and vessel ventilation lines have been omitted for clarity.

Not to Scale

H96110259.10d

Figure 3-6. Schematic of the 324 Building Low-Level Vault Process Piping for Tank 102. 


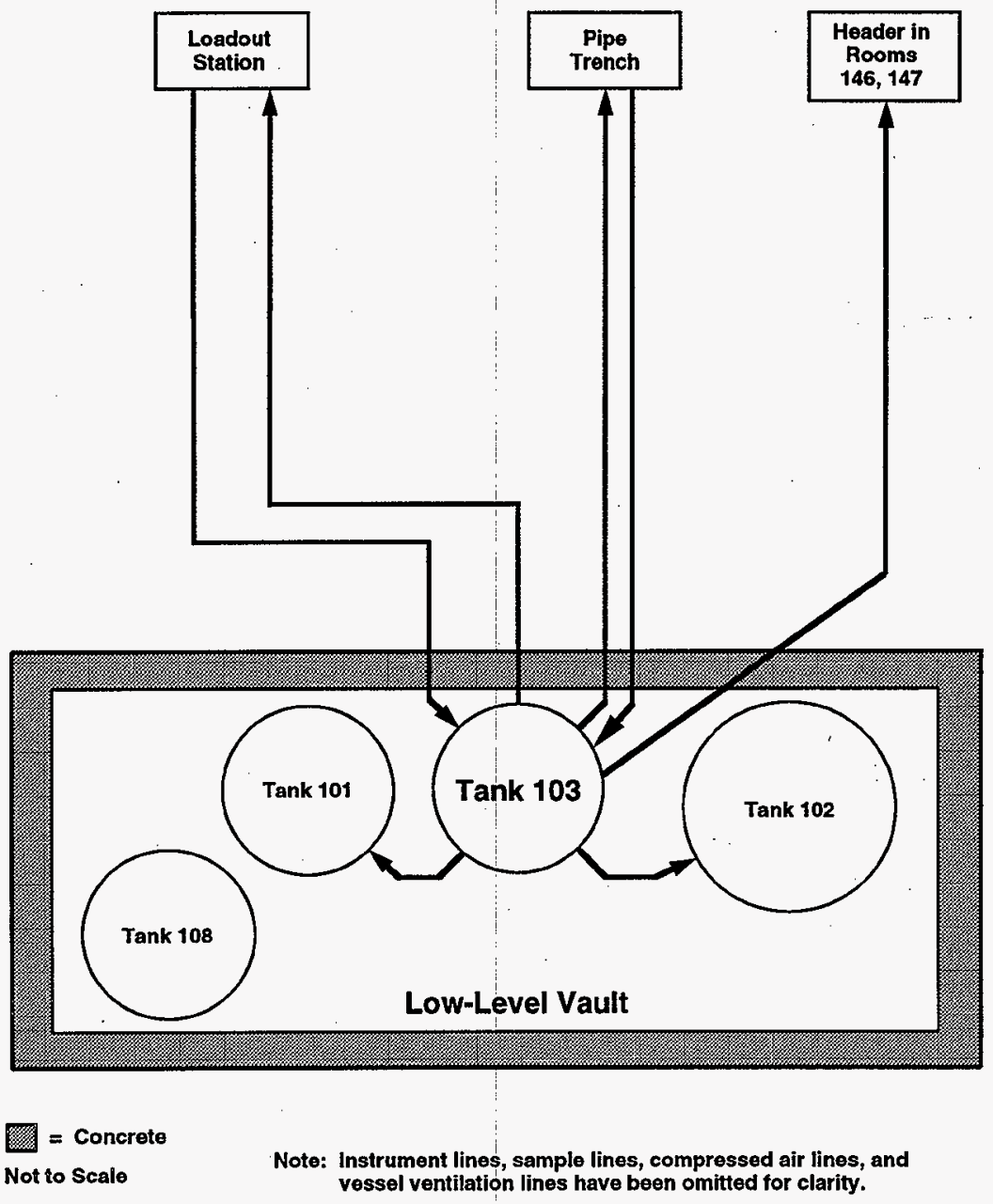

H96110259.11a

Figure 3-7. Schematic of the 324 Building Low-Level Vault Process Piping for Tank 103. 


\section{EDL-146 (Room 146) \\ Drains}

\section{Pipe \\ Trench}
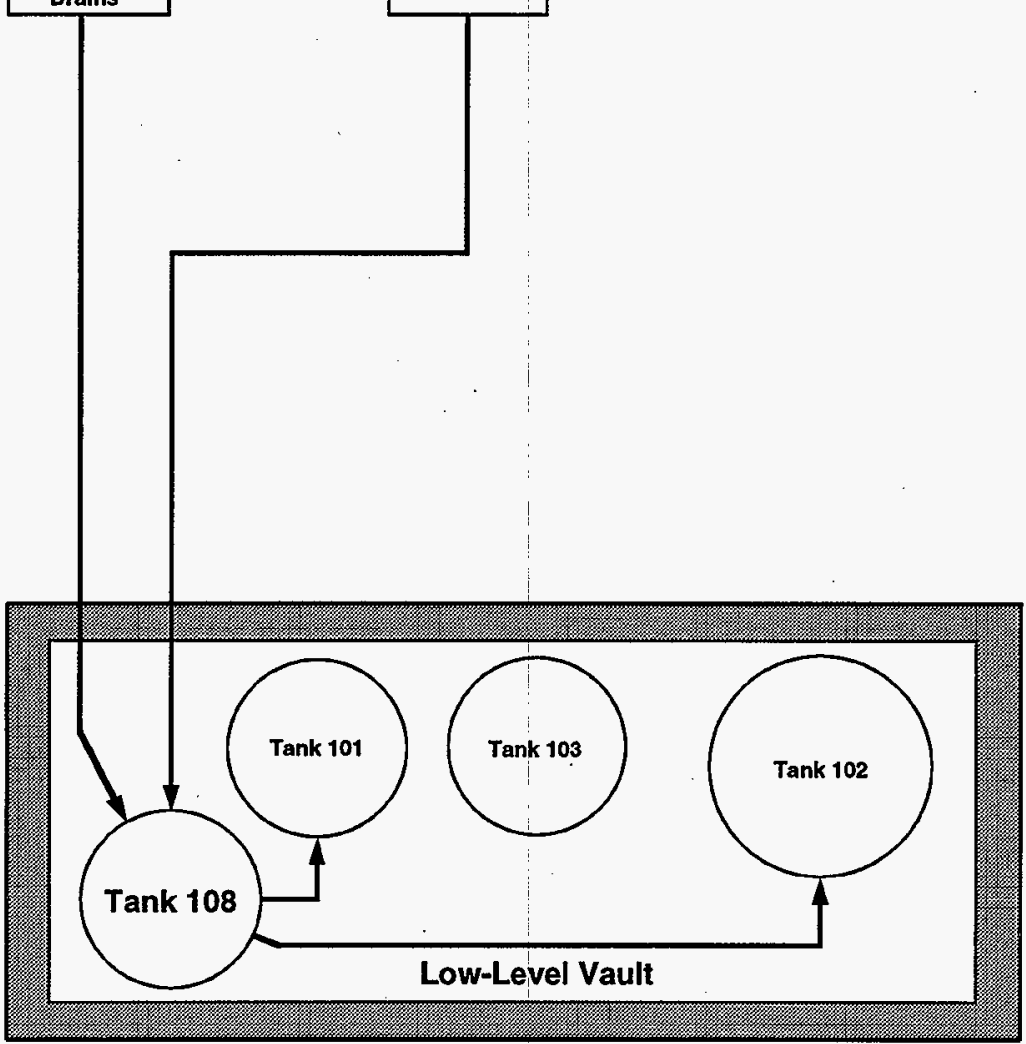

$E D L=$ Engineering Development Laboratory.

裂 $=$ Concrete

Not to Scale

Note: Instrument lines, sample lines, compressed air lines, and vessel ventilation lines have been omitted for clarity.

H9661 t0259.12d

Figure 3-8. Schematic of the 324 Building Low-Level Vault Process Piping for Tank 108. 


\section{CONTENTS}

4.0 WASTE CHARACTERISTICS ....................... 1

4.I RADIOCHEMICAL ENGINEERING CELLS WASTE INVENTORY AND CHARACTERISTICS ..................... 1 4.1.1 Dispersible Debris . . . . . . . . . . . . . 1

4.1 .2 Elemental Lead . . . . . . . . . . . . . 2

4.1.3 Dried Melter Feed Heels . . . . . . . . . . . . 2

4.1.4 Liquid Metal Seal .............. 3

4.1.5 Window $0 \mathrm{il}$ and 0il-Absorption Material ........ 3

4.1.6 Filters Containing Heavy Metals ......... 3

4.2 VAULT TANK WASTE INVENTORY AND CHARACTERISTICS ....... 3

\section{TABLES}

4-1 Radiochemical Engineering Cel1s Dangerous Waste Characteristics . . T4-1 4-2 Vault Tanks Dangerous Waste Designations .......... T4-2 4-3 Dangerous Waste Constituent Concentrations in Collected B-Cell Floor 4-4 Dispersible Debris . . . . . . . T4-3 4-5 Analytical Results of High-Level Vault Tanks . . . . . . T4-5 4-6 Vault Tanks Inductively Coupled Plasma Analytical Results . . . T T4-6 4-7 Dangerous Waste Codes Associated with Areas Undergoing Closure . . T4-7 
This page intentionally left blank. 


\subsection{WASTE CHARACTERISTICS}

This chapter describes the quantities and characteristics of the waste stored in the REC, HLV and LLV. The description of the waste characteristics is based on an evaluation of process records, process knowledge, and available waste analyses data. The quantities of waste are the estimated volumes that existed before inventory remova1. The information is summarized in Tables 4-1 and $4-2$.

\subsection{RADIOCHEMICAL ENGINEERING CELLS WASTE INVENTORY AND CHARACTERISTICS}

Mixed-waste generation occurred in B-Cell. The one sealed container that was located in $\mathrm{D}$-Cell contained dangerous waste that was generated and initially stored in B-Cell. The container was transferred to D-Cell for fire safety reasons. This container was removed from $D-C e 11$ and disposed in January 1996.

The contamination in B-Cell occurred primarily during pilot-scale testing of vitrification technologies. In 1986, melter feed consisting of a nitric acid solution containing cesium and strontium isotopes was spilled on the southeast portion of floor in B-Cell during RLFCM operations. A substantial fraction of this debris could be dispersible because of its small particle size. Additionally, small tools, pieces of manipulator boots, air hoses, water hoses, pieces of pipe, etc., have been dropped to the floor during cell operations. These items might have been contaminated by the spilled material.

From a review of analytical data and process and operating records, and a comparison with the designation criteria of 40 CFR 261 and WAC 173-303, several waste streams in the REC have been designated as mixed waste. These waste streams are classified as follows:

- Dispersible debris contaminated with spilled feed material

- Elemental lead

- Dried melter feed heels

- Liquid metal seal

- Window oil and oil absorption material.

Table 4-1 provides a list of the dangerous waste in $\mathrm{B}-\mathrm{Ce} 11$ and $\mathrm{D}-\mathrm{Ce} 11$, the dangerous waste codes, and provides an estimate of maximum inventory.

\subsubsection{Dispersible Debris}

Dispersible debris, located in B-Ce11, consists of dirt, dust, process residues, and equipment and tools that collected on the floor during operations. Additionally, the dispersible debris includes 'one time' or sporadically-spilled feed material that contained heavy metals and radionuclides from $\mathrm{B}-\mathrm{Ce} 11$ process equipment. The dangerous waste constituents present are cadmium, chromium, and lead. 
Ten containers of dispersible material have been characterized. After collecting the dispersible material from the floor, nonhazardous metal and tools were segregated from the material and packaged into containers. Once the material was placed in containers, the containers were moved to a work station in front of a cell window where a vertical core of the material was obtained using a manipulator controlled augler sampler. An aliquot of the sample was removed for analysis.

Five grams of each sample were analyzed using the toxicity characteristics leaching procedure (TCLP) to determine the dangerous constituent content of the waste. The extract from the TCLP was analyzed using inductively coupled plasma (ICP) spectroscopy. The analysis included

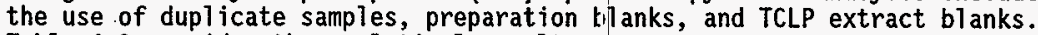

It has been estimated that the dispersible debris within B-Cell contains about 1.5 million curies (Mci) of radioactive materials, primarily cesium and strontium isotopes. This material is being collected and packaged in 0.09 -cubic-meter canisters. Based on the levels of transuranic (TRU) radionuclides identified from sample analysis, the dispersible debris have been classified as TRU mixed waste.

The dispersable debris collected to date has been transferred to the PUREX storage tunnels (Ecology 1996) for long-term storage. As more material is collected and designated as mixed waste, it will be transferred to an onsite TSD unit or shipped off-site to a TȘD facility.

\subsubsection{Elemental Lead}

Approximately 0.7 cubic meter of lead that was used as shielding or counterbalance weight in B-Cell and 0.09 cubic meter of lead shot has been stored in $\mathrm{B}-\mathrm{C}$ l11. Lead that was poured into the legs of equipment for stability will be removed from B-Cell with the equipment. Process knowledge was used to designate the lead. The elemental lead that has been collected to date, which was remote-handled mixed waste, was transferred to the PUREX storage tunnels (Ecology 1996) for long-term storage.

\subsubsection{Dried Melter Feed Heels}

Small process feed tanks that are located in $\mathrm{B}-\mathrm{Ce} 11$ were used during the FRG Program melter testing project and other pilot process operations. The feed solution in the tanks dried up, leaving a highly radioactive and potentially dangerous waste. This dried material is referred to as dried melter feed. The dangerous waste constituents present are chromium and lead. During previous cleanup activities in $\mathrm{B}-\mathrm{Ce} 1 \mathrm{l}$, approximately 0.17 cubic meter of this material was removed from the tanks and placed in 11-liter steel-tube containers: This material has been transferred to the PUREX storage tunnels (Ecology 1996) for long-term storage.

51 


\subsubsection{Liquid Metal Seal}

The liquid metal seal is a metal alloy containing 50 percent bismuth, 26.7 percent lead, 13.3 percent tin, and 10 percent cadmium. This alloy has a melting point of $70^{\circ}$ Centigrade, and it was used as a seal material as part of the glass melter. The waste as packaged is $<0.2$ cubic meter in volume, and was transferred to the PUREX storage tunnels (Ecology 1996).

\subsubsection{Window $0 i 1$ and 0il-Absorption Material}

An absorption material was used to clean up mineral oil from a leaking window in B-Cel1. The material was contained within a 208-liter container that was moved to $D-C e 11$ because of flammability considerations. (Torches were being used to cut up equipment being removed from B-Ce11.) The oil and associated absorbent material were designated as state-only toxic, dangerous waste number WTO2. This material was transferred to the PUREX storage tunnels (Ecology 1996).

\subsubsection{Filters Containing Heavy Metals}

Additionally, there are filters containing heavy metals from the HLV liquid waste treatment process performed in 1996. These filters are considered mixed waste and are being stored in D-Cell where the treatment process took place. The filters will be moved to B-Cell as soon as practical and will be disposed of along with the dispersible material located in B-Cell.

\subsection{VAULT TANK WASTE INVENTORY AND CHARACTERISTICS}

Liquids that were generated within the REC had been discharged to the vault tanks since 1968. The HLV tanks have been used as holding tanks for feed solutions, feedstock tanks for process solutions, and collection tanks for process effluents. Three of the HLV tanks (tanks 104, 105, and 107) had contained leftover research feed materials, which were declared mixed waste when no further use for the material could be identified. The HLV tanks were drained and flushed in 1996 (Chapter 3.0, Section 3.3.1.5).

Analyses of the contents in the vault tanks were conducted in 1990. Analyses were conducted for several analytes, including those of greatest importance for designating the waste. Analytical results of the samples are provided in Tables 4-4, 4-5, and 4-6. Table 4-2 provides the dangerous-waste designations for waste in the HLV tanks.

The analytical results are most representative of waste generated during and following the FRG Program, with the exception of tank 107, that was not used during the FRG Program and had contained waste from NWVP. 
Before liquid treatment activities for the HLV tanks (performed in 1996), tank 104 contained approximately 1,500 litiers of dilute solution of radioactive cesium nitrate and strontium nitrate. Tank 105 contained approximately 1,900 liters of a dilute solition of radioactive cesium nitrate and strontium nitrate. During the operation of the WSEP and the NWVP, tanks 104 and 105 were set up to receive the bottoms from the evaporator and the acid fractionater, respectively. The acid fractionater was used as a second-stage evaporator. Tank 105 also received feed materials from the feed makeup tank. During operation of the FRG Program, tanks 104 and 105 (primarily tank 105) were used to contain nadioactive strontium and cesium nitrate feed material for the RLFCM. These feed materials contained residual fluorides and chlorides from the conversion of original feed material to nitrates (performed in the 200 Areas).

Documented process knowledge and a review of operating records indicate that tank 106 in the HLV contained no liquids prior to liquid waste treatment activities in 1996. Tank 106 had been used during the NWVP to accept highlevel liquid waste from the $325 \mathrm{~A}$ Building.

Tank 107 contained approximately 625.4 1iters of a process feedstock solution. Tank 107 was used routinely during WSEP and NWVP as a container for feed materials before the materials were sent to the melter-feed makeup tank. During NWVP, nonradioactive feed additions, including phosphoric acid, were made directiy to tank 107. The FRG Prograri did not use tank 107.

A summary of dangerous waste codes that are associated with areas undergoing closure is provided in Table 4-?. 
DOE/RL-96-73, Rev. 0

Table 4-1. Radiochemical Engineering Cells Dangerous Waste

2 Characteristics.

\begin{tabular}{|c|c|c|c|c|}
\hline Location* & Waste type & $\begin{array}{c}\text { Waste } \\
\text { designation }\end{array}$ & $\begin{array}{l}\text { Dangerous } \\
\text { constituents }\end{array}$ & $\begin{array}{l}\text { Estimated } \\
\text { quantity }\end{array}$ \\
\hline B-Cell & $\begin{array}{l}\text { Dispersible } \\
\text { debris }^{(a)}\end{array}$ & $\begin{array}{l}\text { D006, D007, } \\
\text { D008, WT02 }\end{array}$ & $\begin{array}{l}\text { Cadmium, } \\
\text { chromium, } \\
\text { Tead, toxic }\end{array}$ & $2.5 \mathrm{~m}^{3}$ \\
\hline B-Cell & Elemental lead & D008, WT01 & Lead, toxic & $1.0 \mathrm{~m}^{3}$ \\
\hline B-Cell & $\begin{array}{l}\text { Dried melter } \\
\text { feed heels }\end{array}$ & $\begin{array}{l}\text { D007, D008, } \\
\text { WT01 }\end{array}$ & $\begin{array}{l}\text { Chromium, } \\
\text { Tead, toxic }\end{array}$ & $0.17 \mathrm{~m}^{3}$ \\
\hline B-Cel1 & $\begin{array}{l}\text { Liquid metal } \\
\text { seal }\end{array}$ & $\begin{array}{l}\text { D006, D008, } \\
\text { WT01 }\end{array}$ & $\begin{array}{l}\text { Cadmium, } \\
\text { lead, toxic }\end{array}$ & $<0.2 \mathrm{~m}^{3}$ \\
\hline D-Cel1 & $\begin{array}{l}\text { Window oil and } \\
\text { oil absorption } \\
\text { material }\end{array}$ & WT02 & Toxic & $<0.2 \mathrm{~m}^{3}$ \\
\hline
\end{tabular}

* location of waste when it was stored in the REC; waste collected to date 
Table 4-2. Vault Tanks Dangerous Waste Designations.

\begin{tabular}{|c|c|c|c|}
\hline Tank & Waste type & $\begin{array}{c}\text { Waste } \\
\text { designation }\end{array}$ & $\begin{array}{l}\text { Dangerous } \\
\text { constituents }\end{array}$ \\
\hline \multicolumn{4}{|c|}{ High Level Vault Tanks } \\
\hline TK-104 & $\begin{array}{l}\text { Di7ute }{ }^{90} \mathrm{Sr} \text { nitrate and } \\
{ }^{377} \mathrm{Cs} \text { nitrate solutions }\end{array}$ & D002, D008, WTO2 & $\begin{array}{l}\text { Corrosive, lead, } \\
\text { toxic, } \mathrm{pH} 1.4\end{array}$ \\
\hline TK-105 & $\begin{array}{l}\text { Di7ute }{ }^{90} \mathrm{Sr} \text { nitrate and } \\
{ }^{137} \mathrm{Cs} \text { nitrate solutions }\end{array}$ & D002, D008, WT02 & $\begin{array}{l}\text { Corrosive, lead, } \\
\text { toxic, pH } 1.5\end{array}$ \\
\hline TK-106 & $\begin{array}{l}\text { Low-level waste process } \\
\text { solution }\end{array}$ & None & None \\
\hline TK-107 & $\begin{array}{l}\text { NWVP liquid process } \\
\text { feedstock solution }\end{array}$ & $\begin{array}{l}\text { D005, D006, } \\
\text { D007, D002, WT02 }\end{array}$ & $\begin{array}{l}\text { Barium, cadmium, } \\
\text { chromium, } \\
\text { corrosive, toxic }\end{array}$ \\
\hline \multicolumn{4}{|c|}{ Low Level Vault Tanks } \\
\hline TK-101 & Low-1evel condensate & None & None \\
\hline TK-102 & Low-level condensate & D004, D005, D008 & $\begin{array}{l}\text { Arsenic, Barium, } \\
\text { Lead }\end{array}$ \\
\hline TK-103 & Low-level condensate & D005 & Barium \\
\hline TK-108 & Contaminated nitric acid & 0007 & Chromium \\
\hline
\end{tabular}

$13 \quad$ NWVP $=$ Nuclear Waste Vitrification Program.

Isotopes:

${ }^{90} \mathrm{Sr}=$ strontium-90.

${ }_{17}{ }^{137} \mathrm{Cs}=$ strontium-90. 
Table 4-3. Dangerous Waste Constituent Concentrations in Collected B-Cell Floor Dispersible Debris.

\begin{tabular}{|c|c|c|c|c|c|c|c|}
\hline $\begin{array}{c}\text { Container } \\
\text { number }\end{array}$ & $\underset{(\mathrm{ppm})}{\mathrm{Ba}}$ & $\underset{(p p m)}{C d}$ & $\underset{(p p m)}{C r}$ & $\begin{array}{c}\mathrm{Pb} \\
\text { (ppm) }\end{array}$ & $\underset{\text { (ppm) }}{\mathrm{Se}}$ & $\underset{(\mathrm{ppm})}{\mathrm{Ag}}$ & $\begin{array}{c}\text { As } \\
\text { (ppm) }\end{array}$ \\
\hline$E C-14$ & 0.64 & 0.35 & 0.09 & 0.09 & ND & ND & ND \\
\hline$E C-15$ & $<0.01$ & $<0.02$ & $<0.03$ & $<0.08$ & $<0.13$ & $<0.02$ & $<0.1$ \\
\hline$E C-16$ & 1.80 & 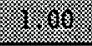 & 0.87 & 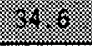 & ND & ND & 0.17 \\
\hline$E C-17$ & 1.04 & 0.73 & 1.10 & 3.75 & ND & ND & ND \\
\hline$E C-19$ & $<0.01$ & $<0.02$ & $<0.03$ & $<0.08$ & $<0.13$ & $<0.02$ & $<0.1$ \\
\hline$E C-21$ & 1.50 & 0.90 & 0.35 & 8 & ND & ND & ND \\
\hline$E C-22$ & 1.45 & 0.59 & 0.27 & $4 \%$ & ND & ND & 0.11 \\
\hline$E C-23$ & 1.03 & 0.70 & 0.30 & 4 & ND & ND & 0.12 \\
\hline$E C-24$ & 0.97 & 0.37 & 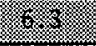 & $4 \%$ & 0.7 & ND & 0.28 \\
\hline$E C-25$ & 1.00 & 0.60 & 0.30 & 4.95 & ND & ND & ND \\
\hline $\begin{array}{l}\text { TCLP Limits - } \\
\text { DW }\end{array}$ & 100 & 1 & 5 & 5 & 1 & 5 & 5 \\
\hline & & & & & & & \\
\hline
\end{tabular}

18 *TCLP results.

19 NOTE: Shading denotes results that are above TCLP DW 1 imits.

DW = dangerous waste.

$\mathrm{EC}=$ engineered container.

ND $=$ not detected.

TCLP $=$ toxicity characteristic 1eaching procedure.

$\mathrm{Ba}=$ barium.

$\mathrm{Cd}=$ cadmium.

$\mathrm{Cr}=$ chromium.

$\mathrm{Pb}=$ lead.

$\mathrm{Se}=$ selenium.

$\mathrm{Ag}=$ silver.

As $=$ arsenic.

$\mathrm{ppm}=$ part per million. 


\begin{tabular}{|c|c|c|c|c|}
\hline Analyses & TK-101 & TK-102 & TK-103 & TK-108 \\
\hline $\mathrm{pH}$ & 6.3 & 7.3 & 8.4 & $<1$ \\
\hline $\begin{array}{l}\text { Total Uranium, } \\
\mu \mathrm{g} / \mathrm{mL}\end{array}$ & 0.17 & 0.11 & 0.30 & $<0.19$ \\
\hline Fluoride, ppm & $<20$ & 1.5 & 7.6 & 146 \\
\hline Chloride, ppm & 143 & 65 & 166 & 218 \\
\hline Nitrate, ppm & 60 & $<0.8$ & 0.8 & 27,900 \\
\hline Nitrite, ppm & $<40$ & $<0.8$ & $<0.8$ & 1000 \\
\hline Phosphate, ppm & 1630 & 405 & 55 & $<40$ \\
\hline Sulfate, ppm & 204 & 115 & 188 & 152 \\
\hline${ }^{90} \mathrm{Sr}, \mathrm{d} / \mathrm{m}-\mathrm{mL}$ & $1.38 \mathrm{E} 6$ & $3.65 \mathrm{E} 5$ & $1.76 \mathrm{E} 6$ & $2.16 \mathrm{E7}$ \\
\hline${ }^{137} \mathrm{Cs}, \mathrm{d} / \mathrm{m}-\mathrm{mL}$ & $6.54 \mathrm{E} 6$ & $1.81 \mathrm{E} 6$ & $6.80 \mathrm{E} 6$ & $5.25 \mathrm{E} 8$ \\
\hline${ }^{134} \mathrm{Cs}, \mathrm{d} / \mathrm{m}-\mathrm{mL}$ & $2.41 \mathrm{E3}$ & $1.10 \mathrm{E} 3$. & $3.83 \mathrm{E} 3$ & NA \\
\hline${ }^{154} \mathrm{Eu} \mathrm{d} / \mathrm{m}-\mathrm{mL}$ & $3.11 \mathrm{E} 4$ & NA & NA & $\mathrm{NA}$ \\
\hline${ }^{241} \mathrm{Am} \mathrm{d} / \mathrm{m}-\mathrm{mL}$ & NA & NA & NA & NA \\
\hline Total alpha d/m-mL & $5.04 \mathrm{E5}$ & $2.31 \quad E 3$ & $8.83 \mathrm{E3}$ & $5.41 E 3$ \\
\hline
\end{tabular}

18 Isotopes:

$19{ }^{90} \mathrm{Sr}=$ strontium-90

$20 \quad{ }^{137} \mathrm{Cs}=$ cesium-137

$21 \quad{ }^{134} \mathrm{Cs}=$ cesium-134

$22 \quad{ }^{154} \mathrm{Eu}=$ europium-154

$23 \quad{ }^{24} \mathrm{Am}=$ americium-241

$\mathrm{d} / \mathrm{m}-\mathrm{mL}=$ disintegrations per minute per milliliter

$\mu \mathrm{g} / \mathrm{mL}=$ micrograms per milliliter

$\mathrm{ppm}=$ parts per million

$\mathrm{NA}=$ not available 
Table 4-5. Analytical Results of High-Level Vault Tanks (1990).

\begin{tabular}{|c|c|c|c|c|}
\hline Analyses & Tank 104 & Tank 105 & Tank 106 & Tank 107 \\
\hline $\mathrm{pH}$ & 1.4 & 1.5 & 6.19 & 0.7 \\
\hline Total uranium, $\mu \mathrm{g} / \mathrm{mL}$ & 0.17 & 0.96 & $4 \mathrm{E}-2$ & 4.9 \\
\hline Fluoride, ppm & NA & NA & 34 & NA \\
\hline Chloride, ppm & $<500$ & NA & 152 & $<15$ \\
\hline Nitrate, ppm & 6,287 & NA & NA & 123,600 \\
\hline Nitrite, ppm & NA & NA & 89 & NA. \\
\hline Phosphate, ppm & NA & NA & $<40$ & NA \\
\hline Sulfate, ppm & NA & NA & $<40$ & NA \\
\hline${ }^{90} \mathrm{Sr}, \mathrm{d} / \mathrm{m}-\mathrm{mL}$ & $1.52 \mathrm{Eg}$ & $1.40 \mathrm{E} 10$ & $3.54 \mathrm{E} 6$ & $9.23 \mathrm{E} 10$ \\
\hline${ }^{137} \mathrm{Cs}, \mathrm{d} / \mathrm{m}-\mathrm{mL}$ & $1.09 \mathrm{Eg}$ & $2.64 \mathrm{E} 10$ & $5.22 \mathrm{E} 6$ & $1.42 \mathrm{E} 11$ \\
\hline${ }^{134} \mathrm{Cs}, \mathrm{d} / \mathrm{m}-\mathrm{mL}$ & NA & NA & $4.22 \mathrm{E} 4$ & $6.47 \mathrm{E} 8$ \\
\hline${ }^{154} \mathrm{Eu} \mathrm{d} / \mathrm{m}-\mathrm{mL}$ & NA & NA & $5.69 \mathrm{E} 4$ & $1.50 \mathrm{Eg}$ \\
\hline${ }^{241} \mathrm{Am} \mathrm{d} / \mathrm{m}-\mathrm{mL}$ & NA & $1.55 \mathrm{E} 5$ & NA & NA \\
\hline Total alpha $\mathrm{d} / \mathrm{m}-\mathrm{mL}$ & $1.65 \mathrm{E} 4$ & NA & $9.00 \mathrm{E} 4$ & $2.32 \mathrm{Eg}$ \\
\hline
\end{tabular}

Isotopes:

${ }^{90} \mathrm{Sr}=$ strontium-90

${ }^{137} \mathrm{Cs}=$ cesium-137

${ }^{134} \mathrm{Cs}=$ cesium-134

${ }^{154} \mathrm{Eu}=$ europium-154

${ }^{241} \mathrm{Am}=$ americium-241

$\mathrm{d} / \mathrm{m}-\mathrm{mL}=$ disintegrations per minute per milliliter.

$\mu \mathrm{g} / \mathrm{mL}=$ micrograms per milliliter.

$\mathrm{ppm}=$ parts per million.

NA = not available. 
Table 4-6. Vault Tanks Inductively Coupled Plasma Analytical Results (results in $\mu \mathrm{g} / \mathrm{mL}$ ).

\begin{tabular}{|c|c|c|c|c|c|c|c|}
\hline \multirow[b]{2}{*}{ Constituent } & & \\
\hline & TK-101 & TK-102 & TK-103 & TK-108 & TK-104 & TK-106 & TK-107 \\
\hline Aluminum & 478 & 2000 & 379 & 23.5 & 3.0 & 367 & 175 \\
\hline Arsenic & $N A$ & (24) & NA & NA & NA & $(4.9)$ & NA \\
\hline Boron & 396.4 & 176 & 281 & 42 & 5.47 & 262 & 131 \\
\hline Barjum & 97.5 & 404 & 822 & 70 & 1.90 & 78.6 & 1074 \\
\hline Beryllium & NA & $\mathrm{NA}$ & $\mathrm{NA}$ & NA & NA & NA & 394 \\
\hline Calcium & 204.3 & 734 & 172 & 25.0 & 12.6 & 165 & 44 \\
\hline Cadmium & NA & NA & NA & NA & NA & NA & 800 \\
\hline Cobalt & NA & NA & NA & NA & NA & NA & 405 \\
\hline Chromium & 4.87 & 1.1 & $(0.6)$ & 27 & 0.48 & .43 & NA \\
\hline Copper. & NA & 1.7 & 0.79 & $\mathrm{NA}$ & 5.04 & 26.8 & $\mathrm{NA}$ \\
\hline Dysprosium & NA & NA & $\mathrm{NA}$ & NA & 2.84 & NA & NA \\
\hline Iron & 40.4 & 237 & 24.9 & 100 & 7.88 & 144 & 12200 \\
\hline Potassium & 79 & 99 & 79 & $\mathrm{NA}$ & 2.1 & 22 & 820 \\
\hline Lanthanum & NA & NA & $\mathrm{NA}$ & NA & 2.0 & NA & NA \\
\hline Lithium & $\mathrm{NA}$ & $\mathrm{NA}$ & NA & $\mathrm{NA}$ & NA & NA & 44 \\
\hline Magnesium & 10.3 & 25 & 11.2 & $\mathrm{NA}$ & 2.84 & 13 & 220 \\
\hline Manganese & 2.66 & 1.6 & 1.1 & 645 & 5.42 & 0.51 & 1340 \\
\hline Sodium & 1477 & 3950 & 1497 & NA & 45.9 & 731 & 190 \\
\hline NickeT & 8.22 & 1.5 & $\mathrm{NA}$ & 30 & 1.49 & 3.6 & 360 \\
\hline Phosphorus & 477 & 162 & 29 & NA & 11.5 & NA & NA \\
\hline Lead & $\mathrm{NA}$ & 7.4 & $(4.4)$ & NA & 15.6 & 2.10 & NA. \\
\hline Rhodium & $\mathrm{NA}$ & NA & NA & $\mathrm{NA}$ & NA & NA & 830 \\
\hline Selenium & $\mathrm{NA}$ & $\mathrm{NA}$ & $\mathrm{NA}$ & $\mathrm{NA}$ & $\mathrm{NA}$ & NA & 390 \\
\hline Silicon & 310 & 1650 & 429 & 28 & 19.6 & 190.8 & 660 \\
\hline Strontium & 2 & 7.93 & 1.8 & 2.5 & 15.4 & 1.6 & NA \\
\hline Tellurium & NA & NA & $\mathrm{NA}$ & NA & NA & NA & 120 \\
\hline Titanium & 3.9 & 14.8 & 2.7 & 25 & 0.19 & 2.80 & NA \\
\hline Vanadium & NA & NA & NA & $\mathrm{NA}$ & NA & NA & 93 \\
\hline Zinc & 2.1 & 16.5 & 2.8 & 12 & 1.2 & 5.2 & 620 \\
\hline Zirconium & 2.0 & 6.55 & 1.6 & 740 & 2.78 & 1.4 & NA \\
\hline
\end{tabular}

*Tank 105 was not sampled.

Values in () are approaching or at detection limits.

The contents of tank 107 were transfer to tank 112, located in B-Cell, and then sampled.

$\mu \mathrm{g} / \mathrm{mL}=$ micrograms per milliliters

NA $=$ not available 
1 Table 4-7. Dangerous Waste Codes Associated with Areas Undergoing Closure

\begin{tabular}{|c|c|c|}
\hline Area & Components & Waste Codes \\
\hline B-Cell & Tiner, concrete & $\begin{array}{l}\text { D006, D007, D008, } \\
\text { WTO1, WT02 }\end{array}$ \\
\hline \multirow[t]{2}{*}{ D-Cel1 } & waste drum storage area & WTO2 \\
\hline & $\begin{array}{l}\text { HLV liquid treatment process equipment } \\
\text { area }\end{array}$ & $\begin{array}{l}\text { D002, D005, D006, } \\
\text { D007, WT02 }\end{array}$ \\
\hline Airlock & isolate from HLV & NA \\
\hline Pipe Trench & isolate from $\mathrm{HLV}$ & NA \\
\hline HLV & four tanks, piping, liner, concrete & $\begin{array}{l}\text { D002, D005, D006, } \\
\text { D007, WT02 }\end{array}$ \\
\hline LLV & four tanks, piping, liner, concrete & D004, D005, D008 \\
\hline $\begin{array}{l}\text { HLV Sample Room } \\
\text { (room 145) }\end{array}$ & isolate from HLV and LLV & NA \\
\hline EDL-146 & isolate from $H L V$ and $L L V$ & NA \\
\hline Galleries & $\begin{array}{l}\text { isolate HLV an LLV. from chemical make- } \\
\text { up room }\end{array}$ & NA \\
\hline
\end{tabular}

$N A=$ not $a p p l i c a b l e$ 


\section{DOE/RL-96-73, Rev. 0}

$05 / 31 / 97$

This page intentionally left blank.

T4-8 
CONTENTS

3

5.0 GROUNDWATER MONITORING ..................... 5-1

5

11 5-1 Boundary of the 300 Area Operable Units . . . . . . . . . . F5-1

\section{FIGURES}

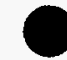




\section{This page intentionally left blank.}




\subsection{GROUNDWATER MONITORING}

The $324 \mathrm{REC} / \mathrm{HLV}$ is not a regulated unit under the definitions of WAC 173-303-040 (i.e., surface impoundment, waste pile, land treatment unit, landfi11) and, therefore, a groundwater monitoring program that is in accordance with WAC 173-303-645 is not required. In accordance. with the Tri-Party Agreement, groundwater in the 300 Area is included in the $300-F F-5$ OU and is being investigated as part of the CERCLA remedial investigation/feasibility study (RI/FS) process. Therefore, groundwater is not addressed as part of the $324 \mathrm{REC} / \mathrm{HLV}$ Closure Plan. The $300-\mathrm{FF}-5$ OU consists of the aquifers beneath the $300-F F-1$ and $300-F F-2$ OUs and is bounded by the Columbia River on the east (Figure 5-1). 
D0E/RL-96-73, Rev. 0

$05 / 31 / 97$

1

2

3

4

This page intentionally left blank. 


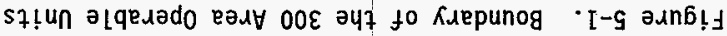

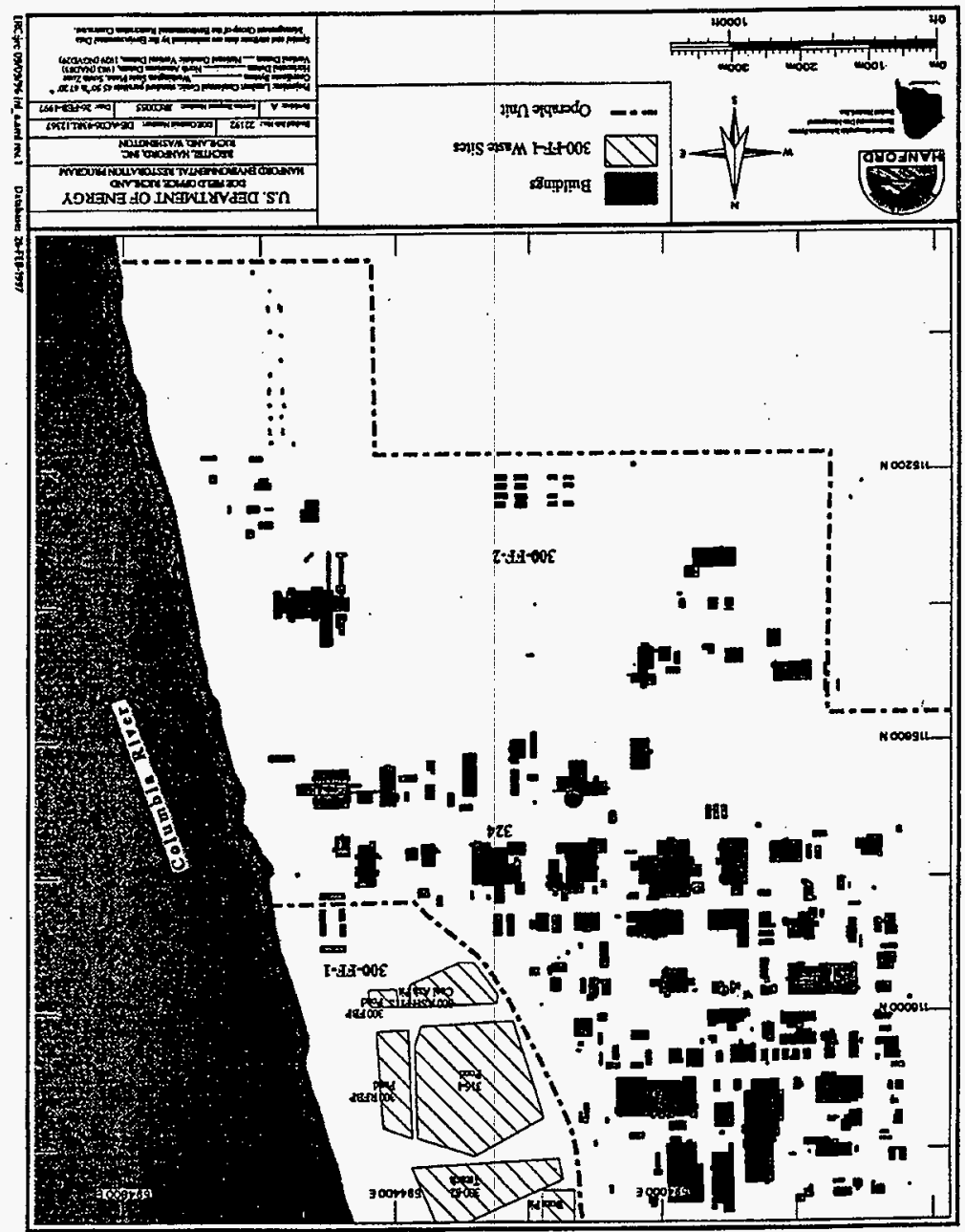

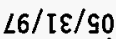

0 • ผәу ' $\varepsilon L-96-7 y / 300$ 
DOE/RL-96-73, Rev. 0

$05 / 31 / 97$

1
2
3
4
5

This page intentionally left blank. 
2

3

4

5

\section{CONTENTS}

6.0 ClOSURE STRATEGY AND PERFORMANCE STANDARDS . . . . . . . . 6-1

6.1 Closure STRATEGY . . . . . . . . . . . 6-1

6.2 ClOSURE PERFORMANCE STANDARDS ............ 6-1

6.2.1 Metal Surfaces and Concrete ............. 6-2

6.2 .2 Tanks ................. 6-2

6.2 .3 Piping ................ 6-3

6.2 .4 Underlying Soil ............. 6-3

6.2 .5 Miscellaneous Building Areas ............ 6-3

6.3 GENERAL ClOSURE ACTIVITIES $\ldots \ldots \ldots$. . . . . . . . 6-3 6.3 .1 B-Cel1 . . . . . . . . . . . . . 6-3 6.3 .2 D-Cell . . . . . . . . $6-4$ 6.3 .3 High-Levei Vault and Low-Levei Vault . . . . . . 6-4 6.3 .4 Piping ................ 6-5 6.3.5 Miscellaneous Building Areas . . . . . . . 6-6

6-1 Closure Performance Standards and Activities for Areas Undergoing Closure ..................... . . . . . . 6 - .

\section{TABLES}




$$
\text { DOE/RL-96-73, Rev. } 0
$$

This page intentionally left blank. 
DOE/RL-96-73, Rev. 0

$05 / 31 / 97$

\subsection{CLOSURE STRATEGY AND PERFORMANCE STANDARDS}

This chapter discusses the closure strategy and performance standards that will be used to close the $324 \mathrm{REC} / \mathrm{HLV}$.

\subsection{CLOSURE STRATEGY}

The 324 Building will be clean closed with respect to dangerous waste contamination that resulted from the treatment or storage of dangerous waste for greater than 90 days. The portions of the 324 Building undergoing closure include: the REC (B-Cell, D-Ce11, airlock, and pipe trench); the HLV and tanks; the LLV and tanks; the piping; and the miscellaneous building areas (the HLV sample room, the EDL-146, and the galleries). Remedial actions with respect to contamination that was not a result of use of these areas for treatment or storage of dangerous waste are outside the scope of this closure plan and will be performed as part of the Facility Decommissioning process.

After the waste inventory has been removed, clean closure of the REC, the HLV and LLV, the piping, and the miscellaneous areas will be accomplished by decontaminating, as necessary, and demonstrating that these components meet the closure performance standards.

Clean closure of the soil immediately beneath the REC and vaults will be accomplished by demonstrating that the building's concrete and liners had kept contaminants from reaching the soi1. Unless inspections identify potential cracks that indicate containment failure and a subsequent potential for soil contamination from waste storage operations, the soil will be considered clean closed. However, if inspections identify through-thickness cracks, investigation into potential soil contamination will be coordinated and integrated with the CERCLA remedial action process for the OU. However, the areas within the 324 Building may be clean closed.

This chapter discusses the strategy for closure of the 324 REC/HLV. However, if a change in strategy occurs before closure is completed and is agreed to and approved by Ecology, the new strategy will be employed and documented as described in Chapter 7.0, Section 7.8.

\subsection{CLOSURE PERFORMANCE STANDARDS}

Clean closure, as provided for in this plan, and in accordance with WAC 173-303-610(2), will reduce future surveillance and maintenance requirements and will protect human health and the environment by removing or reducing dangerous waste contamination to levels that minimize the threat of contaminant escape to the environment.

After the areas within the 324 Building have been clean closed, these areas may be used as necessary to support stabilization and decontamination activities. These potential future uses could include nondangerous waste 
activities, generator status dangerous waste activities, or, with proper permitting, these areas may be used for dangerous waste TSD activities.

After closure, the appearance of the land where the 324 Building is located will be consistent with the appeariance and future use of the surrounding land areas. The 324 Building will remain at the site until final disposition is determined and implemented. Future land use decisions will be considered during the 324 Building decommissioning process. The final disposition of the building and the appearance and use of the 7 and areas will be integrated with the surrounding 300 Areat. Closure performance standards are detailed below and are summarized in Tible 6-1.

\subsubsection{Metal Surfaces and Concrete}

This closure plan proposes use of a 'olean debris surface' (defined in the following paragraph) as the clean closure performance standard for the metal surfaces and concrete that will remain after closure. This approach is consistent with Ecology guidance (Ecology 994 ) for achievement of clean closure.

Attainment of a clean debris surface can be verified visually in accordance with the standard that states, "A clean debris surface means the surface, when viewed without magnification, shall be free of all visible contaminated soil and hazardous waste except residual staining from soil and waste consisting of light shadows, slight sitreaks, or minor discolorations and soil and waste in cracks, crevices, and pilis may be present provided that such staining and waste and soil in cracks, crevices, and pits shall be 1 imited to no more than $5 \%$ of each square inch of surliace area" (40 CFR 268.45).

Decontamination of concrete, per the 'debris rule' is based on a physica? extraction method (40 CFR 268.45, Table 1). The performance standard for physical extraction technologies is based on removal of the contaminated layer of debris. The physical extraction performance standard for concrete is removal of 0.6 centimeter of the surface lilyer and treatment to a clean debris surface.

\subsubsection{Tanks}

The tanks within the HLV and LLV will be removed and disposed. The HLV will be opened and the tanks will be removeid as soon as feasible. The LLV and tanks will remain operational as necessary to support stabilization and decontamination activities, but will ultimately be removed and disposed to achieve clean closure. 


\subsubsection{Piping}

The piping will be flushed and drained as part of closure. The rinsate will be sampled and analyzed. Results of the analysis with less than designation 7 imits for the constituents of concern will be accepted as indicating that the pipes are clean with respect to dangerous waste or dangerous waste residues. During the removal process, the piping and containment will be evaluated to determine whether there was a potential for soil contamination.

\subsubsection{Underlying Soil}

The floor and walls of B-Cell are lined with stainless steel plate that is welded at the seams. Beneath the plate is 15-centimeter concrete. The HLV and the LLV are constructed of concrete and are partially lined with welded stainless steel plate. The soil only could be contaminated if the concrete and liners had failed or where piping and its containment had failed. To determine whether failure had occurred, interior surfaces will be inspected for cracks that (if existing) could have provided a pathway to the soil for contaminants. A similar evaluation will be conducted for the piping and its containment. The inspections will be designed to spot a crack in the liner that is greater than 5 percent of one square inch and may be conducted using a remote camera. If such cracks are not identified, the soil will be considered to be clean closed. However, if such cracks are identified, investigation into potential soil contamination and cleanup will be coordinated and integrated with the CERCLA remedial action process for the OU.

\subsubsection{Miscellaneous Building Areas}

Agreement between Ecology and DOE (Ecology 1997) require that some areas within the 324 Building be isolated from tanks in the HLV and LLV. The closure performance standard for these areas is to isolate the piping as necessary. The airlock and pipe trench will be isolated from the HLV. The pipe trench may be isolated administratively. The HLV sample room (Room 145) and the EDL-146 will be isolated from the HLV and LLV. The piping in the galleries from the chemical make-up room to the vaults will be isolated.

\subsection{GENERAL CLOSURE ACTIVITIES}

Closure of the units within the 324 Building will be performed in accordance with the approved closure plan. Closure activities will be conducted separately for B-Ce11, D-Ce11, HLV, LLV, the piping, and the miscellaneous building areas. Closure activities are summarized in Table 6-1. 


\section{3 .1 B-Cel1}

Before initiating closure activities for B-Cell, all dangerous and mixed waste inventory will be removed as part of the BCCP. General closure activities for $\mathrm{B}-\mathrm{Ce} 11$ will be as follows:

- Inspect liner and exposed concre:e for cracks, potential pathways for dangerous waste to the concrite and soils

- If no cracks are found, this will indicate that no pathway to soil exists and, therefore, the soil beneath $B-C e l l$ is considered clean closed

- If cracks are found, document the finding. Soil characterization and remediation will be coordinated with the CERCLA remedial action process for the $0 \mathrm{U}$.

- Decontaminate the floor and walls

- Perform visual inspection of the liner and concrete and compare to the 'debris rule' performance stindard as a clean closure performance standard (Section 6.2..1)

- Repeat decontamination of the lirier and concrete as necessary and visually re-examine until the performance standard is met.

\section{3 .2 D-Ce11}

General closure activities for the REC: D-Ce11 will be as follows:

- Remove all HLV cleanout equipment. and waste materials

- Visually inspect the portions of the cell that were used to manage waste to meet the 'debris rule' Ferformance standard

- If no contamination is founo, D-Cell is considered clean closed

- If contamination is found, decontaminate the area as required and repeat the visual inspection process until the 'debris rule' standard is achieved and D-Cell is clean closed.

\subsubsection{High-Level Vault and Low-Level Vault}

Before initiating closure activities for the HLV and LLV, dangerous and mixed waste inventory will be removed from the tanks. For the HLV, the inventory was removed in 1996 as part of the $324 \mathrm{HLV}$ interim removal action project (Chapter 3, Section 3.3.1.5). 


\subsubsection{Piping}

General closure activities for the piping will be as follows:

- Identify piping that could have transported dangerous waste

- Only piping that had transported dangerous waste to an area within the closure boundary is within the scope of this closure plan

- Remove piping that is no longer needed to support stabilization and/or deactivation, where practical, evaluate for potential soil contamination if applicable, and dispose of appropriately

- Rinse remaining piping and collect rinsate

- Sample and analyze the rinsate. Designate and dispose of the rinsate appropriately. Repeat the flushing, sampling, and analysis untit the rinsate no longer designates as dangerous waste. The lines will be considered clean closed

- Isolate piping where practical. 
DOE/RL-96-73, Rev. 0 $05 / 31 / 97$

1 6.3.5 Miscellaneous Building Areas

General closure activities for the miscellaneous building areas will be 4 to isolate the piping within the rooms froml the HLV and LLV as appropriate. 


\begin{tabular}{|c|c|c|c|c|}
\hline 2 & Area & Components & Closure Performance Standard & Closure Activities \\
\hline 3 & $\mathrm{~B}-\mathrm{Ce} 11$ & liner, concrete & 'clean debris surface' & $\begin{array}{l}\text { decontaminate and inspect } \\
\text { liner and exposed concrete }\end{array}$ \\
\hline 4 & D-Cel1 & $\begin{array}{l}\text { waste drum storage } \\
\text { area; HLV liquid } \\
\text { treatment process } \\
\text { equipment area }\end{array}$ & 'clean debris surface' & $\begin{array}{l}\text { decontaminate and inspect } \\
\text { liner and exposed concrete }\end{array}$ \\
\hline 5 & Airlock & isolate from HLV & isolate piping & isolate appropriate piping \\
\hline 6 & Pipe Trench & isolate from HLV & isolate piping & isolate appropriate piping \\
\hline 7 & HLV & $\begin{array}{l}\text { four tanks, piping, } \\
\text { liner, concrete }\end{array}$ & $\begin{array}{l}\text { designation limits for piping } \\
\text { rinsate or removal; 'clean } \\
\text { debris surface' for liner and } \\
\text { concrete }\end{array}$ & $\begin{array}{l}\text { open vaults, remove and } \\
\text { dispose of tanks and piping, } \\
\text { visual inspection }\end{array}$ \\
\hline 8 & LLV & $\begin{array}{l}\text { four tanks, piping, } \\
\text { liner, concrete }\end{array}$ & $\begin{array}{l}\text { designation limits for rinsate } \\
\text { for piping or removal; 'clean } \\
\text { debris surface' for } 1 \text { iner and } \\
\text { concrete }\end{array}$ & $\begin{array}{l}\text { open vaults, remove and } \\
\text { dispose of tanks and piping, } \\
\text { visual inspection }\end{array}$ \\
\hline $\begin{array}{r}9 \\
10\end{array}$ & $\begin{array}{l}\text { HLV Sample Room } \\
\text { (room 145) }\end{array}$ & $\begin{array}{l}\text { isolate from HLV and } \\
\text { LLV }\end{array}$ & isolate piping & isolate appropriate piping \\
\hline 11 & EDL-146 & $\begin{array}{l}\text { isolate from } H L V \text { and } \\
\text { LLV }\end{array}$ & isolate piping & isolate appropriate piping \\
\hline 12 & Galleries & $\begin{array}{l}\text { isolate HLV an LLV } \\
\text { from chemical make-up } \\
\text { room }\end{array}$ & isolate piping & isolate appropriate piping \\
\hline
\end{tabular}




\section{CONTENTS}

7.0 ClOSURE ACTIVITIES . . . . . . . . . . . . . 7-1

7.1 CLOSURE ACTIVITIES FOR THE RADIOCHEMICAL ENGINEERING CELLS • • 7-1 7.1.1 Constituents of Concern for Closure for the Radiochemical Engineering Cells ......... 7-1 7.1 .2 Closure Activities for B-Cell ........ 7.1 .3 Closure Activities for D-Cell $\therefore 7-2$ 7.1.4 Closure Activities for the Airlock and Pipe Trench : : 7-3

7.2 CLOSURE ACTIVITIES FOR THE HIGH-LEVEL VAULT AND LOW-LEVEL

VAULT . . . . . . . . . . . . .

7.2.1 Constituents of Concern for Closure of the High-Level Vault and Low-Level Vault ........ 7-4

7.2.2 Closure Activities for the Tanks and Vaults $\ldots . .7-4$

7.3 CLOSURE ACTIVITIES FOR THE PIPING . . . . . . . . . . 7-4

7.4 CLOSURE ACTIVITIES FOR THE MISCELLANEOUS BUILDING AREAS . . . 7-5

7.5 CLOSURE ACTIVITIES FOR THE SOIL DIRECTLY BENEATH THE UNIT . . . 7-5

7.6 REGULATED MATERIAL REMOVED DURING CLOSURE . . . . . . . 7-6

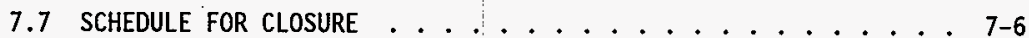

7.8 AMENDMENT OF ClOSURE PLAN ............

7.9 CERTIFICATION OF CLOSURE ............. . . . . .

\section{FIGURES}

7-1 Sample Clean Debris Surface Checklist . . . . . . . . . . F F7-1

7-2 324 Building Closure Activities Schedule . . . . . . . . . F7-2

7-3 Typical Closure Certification Document . . . . . . . F7-3

\section{TABLES}

7-1 Piping that wi11 Undergo Closure ............. . . T7-1 
This page intentionally left blank. 


\subsection{CLOSURE ACTIVITIES}

This chapter discusses the activities that are necessary to implement a clean closure strategy for the units undergoing closure in the 324 Building. The first step for each unit will be the removal of all dangerous waste inventory. After the waste has been removed, clean closure of the REC, the HLV, the LLV, the piping, and the miscellaneous areas will be accomplished by decontaminating the components, as necessary, and demonstrating that clean closure performance standards are met (Chapter 6.0, Section 6.2). Clean closure of the soil will be accomplished by demonstrating that the concrete and liners had kept the contaminants from reaching the soil. If it is determined that soil contamination is possible, investigation and potential cleanup of the soils will be coordinated with the CERCLA remedial action process for the $0 \mathrm{U}$. All work will be performed to maintain worker exposure to dangerous and/or mixed waste, radioactivity, hazardous chemicals, or any other workplace hazards as low as reasonably achievable (ALARA). Inspections may be performed remotely if necessary for ALARA concerns.

\subsection{CLOSURE ACTIVITIES FOR THE RADIOCHEMICAL ENGINEERING CELLS}

The REC consists of the B-Ce11, the D-Cell, the airlock, and the pipe trench. Closure of B-Cell and D-Cell will entail cleaning to a clean debris surface as defined by the 'debris rule' (Chapter 6 , Section 6.2.1). The airlock and pipe trench will be closed by isolating them from the HLV.

\subsubsection{Constituents of Concern for Closure for the Radiochemical Engineering Cells}

The constituents of concern for closure of the REC are described in Chapter 4.0, Section 4.1, and are summarized in Table 4-1. The waste of concern for the closure of B-Cell is dispersible debris, elemental lead, dried melter feed heels, and liquid metal seal. The major constituents of concern are cadmium, chromium, and lead. The D-Cell contained window oil and waste processing equipment from the HLV liquid waste treatment project.

\subsubsection{Closure Activities for B-Cell}

Before initiating closure activities, all dangerous and mixed waste inventory will be removed from B-Cel1. Inventory removal is being performed as part of the BCCP, which includes removal of equipment and radiological decontamination of B-Cell (Chapter 3 , Section 3.2.2.5). A's equipment is removed from $B-C e 11$, the dispersible material on the floor will be collected, containerized, and removed. 
After the BCCP decontamination step, it is anticipated that the B-Cell liner will meet the closure performance stindard. However, any level of dangerous waste contamination found on the liner that is higher than the closure performance standard will be removed from the surface layer using either high-pressure water blasting (a physical extraction method) or by wiping, washing, brushing, or scrubbing using a cleaner approved by Ecology, then rinsing with water, or by other appropriate methods. Decontamination will be repeated until the surface meets the performance standard or it is determined that the decontamination is inefifective. Decontamination residues will be collected, designated, and managed as described in Section 7.6.

After B-Cell has been decontaminated, the cell liner will be inspected to determine whether the surface meets the closure performance standard for metal surfaces and concrete of a 'clean debris surface' (Chapter 6.0, Section 6.2.1). This inspection could be conducted using a remote camera. If it is not possible to meet the clean closure performance standard, contaminated portions of the liner could be: removed, designated, and disposed of accordingly. The inspections for a clean debris surface will be documented on an inspection checklist similar to Figure 7-1.

Visual inspection will also confirm that there are no cracks in the liner. Liquid/dye penetrant, eddy current, or ultrasonic techniques could be used on areas where the visual inspection is inconclusive. Liquid penetrant inspection could be used in addition to the visual inspection to detect defects that break the surface of the B-Cell liner. Liquid penetrant inspection is used to reveal such defects as cracks, laminations, laps, and zones of surface porosity. To achieve good visibility, the liquid is colored with a bright and persistent (usually red) dye or tagged with a fluorescent marker. This method has been proven to be effective in $\mathrm{C}$-Cell decontamination when liquid-penetrant inspection revealed that no macroscopic cracks breached the liner, but it did show that pitting had occurred. However, in $\mathrm{C}-\mathrm{Ce} 11$ the method did not require remote operation. Workers were able to enter $\mathrm{C}-\mathrm{Ce} 11$.

other possible inspection techniques include ultrasonic testing and electrical eddy currents. UTtrasonic inspection should detect internal defects and small surface cracks. An ultrasonic impulse is generated in the substance being tested, and a transducer in contact with the material is used to detect discontinuities in the signal. The nature of the discontinuities is related directly to the type and extent of the defect. Electrical eddy currents can be induced in a material and an assessment of the effects can lead to conclusions about the nature and condition of the material being examined. Eddy current has been used remotely and in high-radiation areas.

If the visual inspection indicates a possible crack in the liner, the B-Cell still will be considered clean closed. However, if cracks are found in the liner that might have resulted in contamination of the soil, the soil characterization and potential cleanup will be coordinated with the CERCLA remediat action process for the $0 U$. 
DOE/RL-96-73, Rev. 0

$05 / 31 / 97$

\subsubsection{Closure Activities for D-Cell}

The initial step for closure of D-Cell will be removal of the waste inventory and the equipment used for the processing of the HLV tank waste. The waste inventory includes the 208- 1 iter container of absorbed waste mineral oil from the window gasket leak. This container was stored in D-Cell from July 1994 until removed in January 1996 and transferred to the PUREX Storage Tunnels, an onsite permitted TSD unit, for storage prior to disposal. The container was inspected before removal from D-Cell and revealed that the integrity of the drum had been maintained. Additionally, filters that contain heavy metals and are considered a dangerous waste associated with the HLV liquid waste treatment process are being stored temporarily in D-Cell. These filters will be transferred to B-Cell and disposed of with the dispersible material in B-Cell.

The HLV liquid waste treatment equipment has been rinsed and is considered to be in a stable state in D-Ce11. The equipment in D-Cell will remain operable for possible use in treating $B-C e 11$ decontamination solutions. After B-Cell decontamination is complete, or as soon as it is determined that this equipment is no longer needed, the equipment will be dismantled and removed from D-Cell for reuse or designated and disposed of accordingly.

After removal of all the waste and HLV liquid waste treatment equipment, the portions of the cell that were used to manage the waste and equipment will be visually inspected to determine whether performance standards were met. If the performance standard is met, D-Cell will be considered clean closed. If the performance standard is not met, the potentially contaminated areas will be decontaminated and re-inspected until the performance standard is met.

\subsubsection{Closure Activities for the Airlock and Pipe Trench}

Per agreement between Ecology and DOE (Ecology 1997), the airlock and pipe trench will be closed by isolating the piping to the HLV. The airlock will continue operation under generator standards. The pipe trench may be isolated using administrative procedures.

\subsection{CLOSURE ACTIVITIES FOR THE HIGH-LEVEL VAULT AND LOW-LEVEL VAULT}

The HLV and LLV each consist of four tanks, the vault liner and concrete, and the piping in the vault. Before initiating closure activities, all dangerous and mixed waste inventory will be removed from the HLV tanks (Section 3.3.1.5). Closure of the HLV and LLV entails removing the tanks and piping, where possible, and cleaning the liner and concrete to a clean debris surface as defined by 40 CFR 268. Closure activities for the HLV are described in Section 7.2.2. Closure of the LLV will occur in a similar manner; however, the LLV will remain active as necessary for use in building decontamination and closure activities. Once it is determined that there is no longer a need for the LLV, the LLV will be closed. 


\subsubsection{Constituents of Concern for Closure of the High-Level Vault and Low-Level Vault}

The constituents of concern for closuine of the HLV and LLV are described in Chapter 4.0, Section 4.2. The waste of concern for the closure of the HLV is dilute strontium and cesium nitrate solutions, low-activity waste process solutions, and NWVP liquid process solutions. The major constituents of concern are lead, barium, cadmium, chromiun, and corrosivity. All the waste was removed from the HLV as part of the HLY liquid waste treatment (Chapter 3 , Section 3.3 .1 .5 ).

\subsubsection{Closure Activities for the Tanks and Vaults}

Closure of the HLV and LLV will entail opening the vault by removing the coverblocks. The tanks will be removed from the vault, designated, and size reduced, as necessary, for disposal. Piping in the vault also will be removed, designated, and disposed of accordingly. As much piping as possible will be removed from the vaults.

Once the tanks and piping have been removed, the vault liner and exposed concrete will be visually inspected to jdentify any potentially contaminated areas. This inspection could be made remotiely using a camera or other device if necessary because of ALARA concerns. This inspection also will examine the liner for potential pathways for dangerous waste to the soil (i.e., cracks). Any cracks found will be assessed to determine if they are potential throughcracks to the soil. Potentially contaminat:ed areas of the liner or concrete areas will undergo decontamination to meet the clean closure standard of a clean debris surface.

Possible decontamination methods for the liner include high-pressure water blasting (a physical extraction method) or by hand or remote wiping, washing, brushing, or scrubbing using an approved cleaner, then rinsing with water, or by other appropriate methods. If potential through-cracks are identified, these will be sealed before using a liquid-based decontamination method on the liner or concrete. Concrete surfaces that are indicated by visual examination as being potentially corltaminated will have the surface layer removed to a depth of 0.6 centimeter by scabbling or other approved methods.

\subsection{CLOSURE ACTIVITIES FOR THE PIPING}

The initial closure activity for the piping that is associated with the areas undergoing closure will be to identify the lines that might have carried dangerous waste. Only piping that might have carried dangerous waste will undergo closure activities. All other piping will be addressed during the Facility Decommissioning process. The piping between the LLV and the Sodium Removal Pilot Plant will be considered in this evaluation. 
As per agreement between DOE and Ecology (Ecology 1997) the following piping will be isolated. The airlock and pipe trench will be isolated from the HLV. The pipe trench may be isolated using administrative procedures. The HLV sample room (Room 145) and the EDL-146 will be isolated from the HLV and the LLV. The piping in the galleries from the chemical make-up room to the vaults will be isolated.

Piping that will undergo closure includes the piping identified in . Table 7-1. Table 7-1 identifies piping between the pipe trench and the vault tanks and the piping between the LLV and the Sodium Removal Pilot Plant in EDL-146. All other piping within the 324 Building will be evaluated in a study scheduled to be complete in 1998.

The piping that will undergo closure will be rinsed and the rinsate will be sampled and analyzed for the constituents of concern. The constituents of concern will be based on knowledge of what constituents were in the dangerous waste carried through the particular piping. If the rinsate does not designate based on the concentrations of the constituents of concern, the piping will be considered clean with respect to this closure. If necessary, the piping will be rinsed with a decontamination solution before sampling and analyses. If it is not possible to meet the clean closure performance standard, the particular piping of concern will be removed and disposed if possible. If it is not possible or practical to remove the piping, the location of the piping of concern will be recorded, and the piping will be isolated. During the removal process, the piping and its containment will be evaluated to determine if there was a potential for soil contamination.

\subsection{CLOSURE ACTIVITIES FOR THE MISCELLANEOUS BUILDING AREAS}

Per agreement between Ecology and DOE (Ecology 1997), the HLV sample room (Room 145) and the EDL-146 will be isolated from the HLV and LLV. Closure of the galleries will consist of isolating the piping from the chemical make-up room to the vaults.

\subsection{CLOSURE ACTIVITIES FOR THE SOIL DIRECTLY BENEATH THE UNIT}

The B-Cel1, HLV, and LLV vaults were designed and installed with a system to collect leaks or spills and to channel these to sumps from which the solutions were pumped back into the tank system. The underlying soil only could be contaminated if the liner and concrete failed. These surfaces will be inspected to identify cracks (if any) that could provide a pathway for dangerous waste or dangerous waste residues to the underlying soil. If no cracks are noted, it will be concluded that the areas have maintained integrity and the soil will be considered clean closed. If it is determined that soil contamination is possible, investigation and potential cleanup of the soil will be coordinated with the CERCLA remedial action process for the ou. 


\subsection{SCHEDULE FOR CLOSURE}

A schedule for closure activities is presented in Figure 7-2. Removal of inventory from B-Ce11, D-Ce11, and the HLV already has begun and is being performed according to Tri-Party Agreement milestones. The schedule proposed is greater than 180 days.

Studies will be conducted to assist and validate the technical baseline development. The dates provided in this schedule will be reevaluated after these studies are completed.

\subsection{AMENDMENT OF CLOSURE PLAN}

If an amendment to the approved closure plan is required, the DOE-RL will submit a written request to Ecology asking for authorization to change the approved plan. The written request will include a copy of the closure plan amendment and will be submitted in accordance with WAC 173-303-610(3). 


\subsection{CERTIFICATION OF CLOSURE}

2

Within 60 days of completing the closure activities the DOE-RL wi71 submit a certification of closure to Ecology. The certification will be signed by the DOE-RL and an independent professional engineer registered in the State of Washington. Certification will state that the areas have been closed in accordance with the approved closure plan (Figure 7-3). The certification will be submitted by registered mail or an equivalent delivery service. Documentation that supports the closure certification will be retained and furnished to Ecology upon request. 


$$
\text { DOE/RL-96-73, Rev. } 0
$$

$05 / 31 / 97$

This page intentionally left blank. 
1

2

3

4

5

6

7

8

9

10

11

12

13

14
15

16

17

18

19

20

21

22

23

24

25
Table 7-1. Piping that will Undergo Closure.

\begin{tabular}{|c|c|c|}
\hline Line Number & From & To \\
\hline TPS-1-42 & pipe trench & TK-101 \\
\hline TPS-1-43 & TK-101 & pipe trench \\
\hline TPS-2-44 & pipe trench & TK-102 \\
\hline TPS-2-45 & TK-102 & pipe trench \\
\hline TPS-3-46 & pipe trench & TK-103 \\
\hline TPS-3-47 & TK-103 & pipe trench \\
\hline TPS-7-329 & pipe trench & TK-107 \\
\hline TPS-5-330 & pipe trench & TK-105 \\
\hline TPS-4-331 & pipe trench & TK-104 \\
\hline TPS-6-332 & pipe trench & TK-106 \\
\hline TPS-6-333 & pipe trench & TK-106 \\
\hline TPS-7-334 & pipe trench & TK-107 \\
\hline TPS-5-335 & pipe trench & TK-105 \\
\hline TPS-4-336 & pipe trench & TK-104 \\
\hline TPS-4-337 & pipe trench & TK-104 \\
\hline TPS-4-338 & pipe trench & TK-104 \\
\hline TPS-5-339 & pipe trench & TK- 105 \\
\hline TPS-5-340 & pipe trench & TK-105 \\
\hline TPS-6-341 & pipe trench & TK-106 \\
\hline TPS $-2-69^{*}$ & TPS-2-70 & TK-102 \\
\hline TPS $-2-70^{*}$ & EDL-146 & TPS-2-69 \\
\hline
\end{tabular}

* Piping between the Sodiun Removal Pilot Plant (located in EDL-146) and the LLV. 
DOE/RL-96-73, Rev. 0

$05 / 31 / 97$

This page intentionally left blank. 


\section{CHECKLIST}

This checklist is intended to document a 'clean debris surface' for the following components, structures, and/or materials.

1. Building/location:

2. Component (s)/Area(s):

3. Material (e.g., concrete, metal):

4. Decontamination/Treatment Method (NA if not performed):

5. Decontamination/Treatment Parameters (NA if not applicable):
a. Temperature
b. Propellant
c. Solid Media (e.g., shot, grit, beads)
d. Pressure
e. Residence time
f. Surfactant (s)
g. Detergents
h. Grinding/striking media (e.g., wheels, piston heads)
i. Depth of surface layer removal (cm) (e.g., for concrete)
j. Other

The decontamination of the components/areas/materials identified in steps 1 through 3 was completed as specified at steps 4 and 5 . Enter NA if decontamination was not performed for these materials.

\section{Title}

$\frac{1}{\text { Signature }}$

6. Performance Standard:

I have visually inspected the above identified material before/after (circle one) decontamination/treatment in accordance with the closure plan (if specified above). All dangerous waste residues have been removed to attain a clean debris surface ${ }^{2}$.

Authorized Representative:

Notes:

1. Although not mandatary, decontamination could use a physical extraction method from Table 1, Alternative Treatment standards for Hazardous Debris (40 CFR 268.45). Treatment will use an appropriate Table 1 method.

2. Clean debris surface as defined in Table 1, Atternative Treatment Standards for Hazardous Debris (40 CFR 268.45): "IClean debris surface' means the surface, when viewed without magnification, shall be free of all visible contaninated soil and hazardous waste except that residual staining from soil and waste consisting of light shadows, slight streaks, or minor discolorations, and soil and waste in cracks, crevices, and pits may be present provided that such staining and waste and soil in cracks, crevices, and pits shall be limited to no more than $5 \%$ of each square inch of surface area."

Figure 7-1. Sample Clean Debris Surface Checklist. 


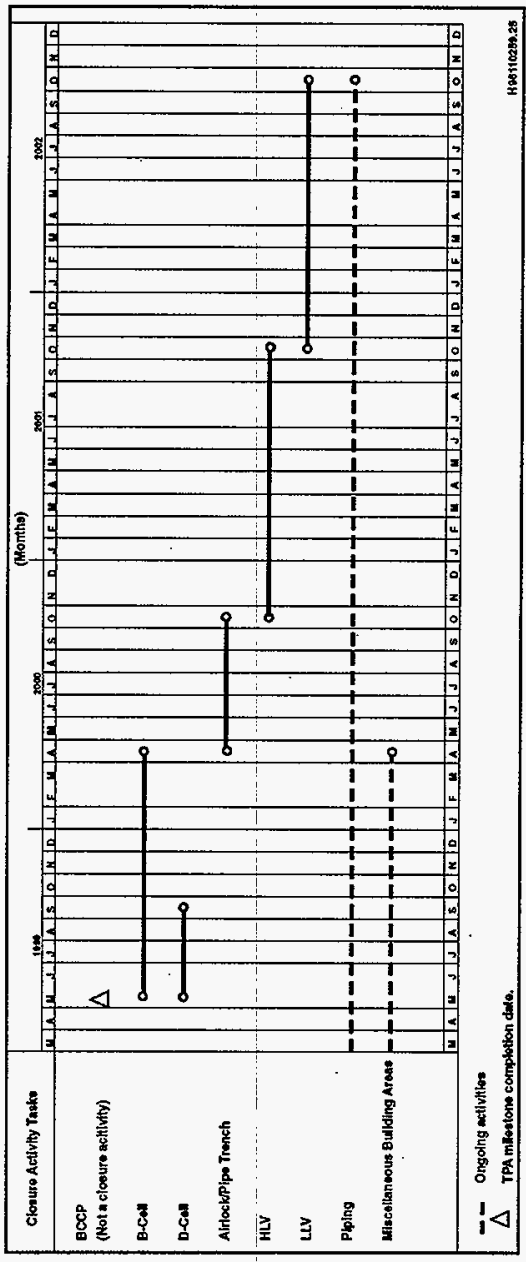

Figure 7-2. 324 Building Closure Activities Schedule. 


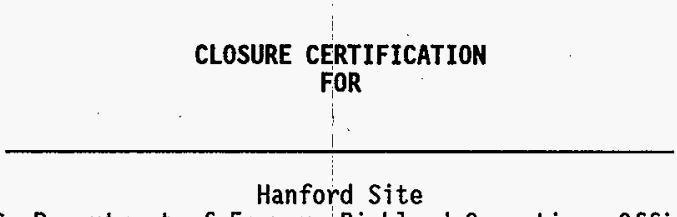

U.S. Department of Energy, Richland Operations office

We, the undersigned, hereby certify that all closure activities were performed in accordance with the specifications in the approved closure plan.

Owner/Operator Signature DOE-RL Representative

(Typed Name)

P.E.\# State

Signature Independent Registered Professional Engineer Date (Typed Name, Washington State Professional Engineer Iicense number, and date of signature)

Figure 7-3. Typical Closure Certification Document. 


\section{This page intentionally left blank.}


DOE/RL-96-73, Rev. 0 $05 / 31 / 97$

2

3

4

$5 \quad 8.0$ POSTCLOSURE ................... 8-1

\section{CONTENTS}

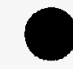

970507.1059

8-i 
DOE/RL-96-73, Rev. 0

$05 / 31 / 97$

This page intentionally left blank. 


\subsection{POSTCLOSURE}

4 This closure plan is proposing clean closure of the areas within the 5324 Building. If the clean closure performance standards are not met and 6 further cleanup is not effective, it is proposed that closure be integrated 7 with and occur during the Facility Decommissioning process. If required, a 8 preclosure work $\mathrm{plan}$ will be prepared in conjunction with development of the 9 transition end-point criteria and the surveillance and maintenance plan for 10 the 324 Building (Ecology et al. 1996, Chapter 8.0).

However, if it is determined that postclosure care is required for the 14 the requirements of WAC $173-303-610(1)(b)$. 
This page intentionally left blank. 
DOE/RL-96-73, Rev. 0

$08 / 15 / 96$

1

2

3

4

5

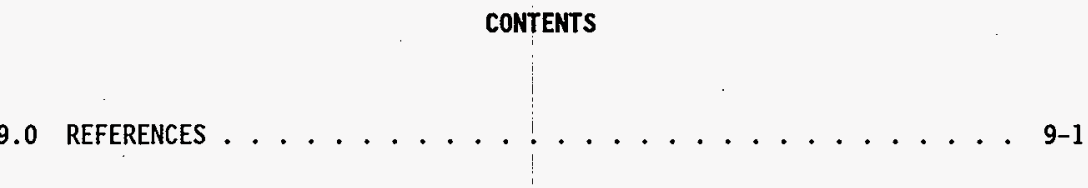


DOE/RL-96-73, Rev. 0

$08 / 15 / 96$

This page intentionally left blank. 


\subsection{REFERENCES}

DOE-RL, 1993a, Letter from J. D. Bauer|to R. F. Stanley, Ecology, and G. C. Hofer, EPA, dated Apri1 30, 1993, "High Activity Radioactive Waste Issues at Hanford," 93-RPA-165, U.S. Department of Energy, Richland Operations Office, Richland, Washington.

DOE/RL-89-14, Draft Remedial Investigation/Feasibility Study Work Plan for the 300-FF-5 Operab7e Unit, Hanford Site, Rich7and, Washington, U.S. Department of Energy, Richland Operations office, Richland, Washington, 1989.

DOE/RL-93-21, Phase III Feasibility Study, U.S. Department of Energy, Richland Operations Office, Richland, Washington, 1993b.

D0E/RL-94-85, The 300-FF-5 Operab7e Units Remedial Investigation/Feasibility Study Report, U.S. Department of Energy, Richland Operations Office, Richland, Washington, 1994.

DOE-RL, EPA, and Ecology, 1995, Letter from S. H. Wisness, DOE-RL, $D$. R. Sherwood, EPA, and R. Stanley, Ecology, regarding agreement of a new Tri-Party Agreement milestone concerning 324 Unit Closures, dated March 20,1995, U.S. Department of Energy, Richland Operations Office; U.S. Environmental Protection Agency; Washington State Department of Ecology, Richland, Washington.

Ecology, 1994, Guidance For Clean Closure of Dangerous Waste Facilities, Publication 94-111, Washington State Department of Ecology, Olympia, Washington.

Ecology, 1995, Letter from D.L. Lundstrom to J.D. Wagoner, DOE-RL, and W. J. Madia, PNNL, dated February 16, 1995, "Dangerous Waste Compliance Inspection of the 324 Building, "Washington State Department of Ecology, 01 ympia, Washington.

Ecology, 1996, Hanford Facility Dangerous Waste Portion of the Resource Conservation and Recovery Act Permit, Permit No. WA7890008967, Part III, Chapter. 3, Washington State Department of Ecology, Olympia, Washington.

Ecology, 1997, Summary of Agreements Reached During the Data Quality Objectives Process: 324 Bui7ding, dated January 10, 1997, Washington State Department of Ecology, 07ympia, Washington.

Ecology, EPA, and DOE, 1996, Hanford Federal Facility Agreement and Consent Order, Washington State Department of Ecology, U.S. Environimental Protection Agency, U.S. Department of Energy, OTympia, Washington.

PNL, 1995a, 324 Building REC and HLV Tank Closure Plan, PNL-10890, Pacific Northwest Laboratory, Richland, Washington. 
DOE/RL-96-73, Rev. 0

$08 / 15 / 96$

1 PNL, 1995b, Project Management Plan Nuclean Facilities Management,

2 PNL Project 19177, Pacific Northwest l.aboratory, Richland, Washington.

3

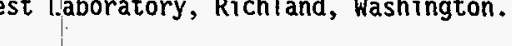




\section{APPENDICES}

$\begin{array}{lll:}4 & & \\ 5 & \text { IA TRI-PARTY AGREEMENT MILESTONE M-89 94-01 }\end{array}$

6
7 2 A 324 BUILDING ENGINEERING DRAWINGS 
D0E/RL-96-73, Rev. 0

$05 / 31 / 97$

This page intentionally left blank. 


\section{APPENDIX 1A}

TRI-PARTY AGREEMENT MILESTONE M-89-94-01 
DOE/RL-96-73, Rev. 0

$05 / 31 / 97$

This page intentionaliy left blank. 


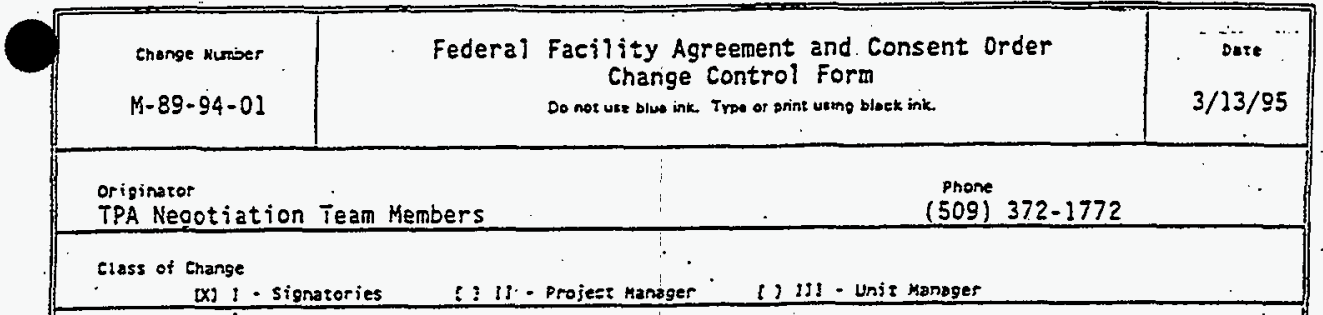

Enange title

Complete closure of non-permitted Mixed Waste (MW) units in the 324 Building Radiochemical Engineering Cell (REC) and Hign Level Vautt (HLV).

Destriptian/dustificazion of Enange

This change package: (1) will result in the establishment of a scheoule for closure of non-permitted MW units located in the 324 Building, 300 Area, Hanford site, and (2) represents a proposed compliance action necessary to correct noncompliance with chapter 173-303 WAC and 40 CFR Part 265 as cited in an Ecology voluntary compliance letier transmitted to USDOE and PNL on February 16, 1995. The approach leading to closure inciudes: 1) achieving compliance with interim status requirements; 2) siabilization of dispersibie materials in the REC B-cell; 3) removal of liquid MW in the HLV ianks; and 4) Submittal of a closure plan under milestone $M-20-55$ and closure of non-permitted MH units in the 324 Buifding (REC B-cell, REC D-Cell, and High Leve) Vaul $t$ ).

(See Attachment for continuation of Descriotion and proposed milestones)

Inose: of change

This change request establishes a new major milestone, M-89-00, to complete the closure of non-permitted MH units in the 324 Building (REC B cel), D-Cell, and HLV). Interim milestones necessary to achieve compliance with interim status standards, siabilization and removal of MH, and closure of non-permitied MW storage units are proposed.

These milestones impact iri-Party Agreement milestone $M-20$

Affeced Dosuments

Kanford Federal Facility Agreement and Consent Oroer, ADpendix D

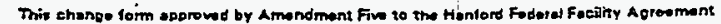
hoprovals and Conent Order exocuned by the cionstoriot on Juty 28, 1995.

$\overline{\text { so: J. D. Wagoner }}$ Date - ioproved Disapproved

EPA C. Clarke - Daze - iporoved Disapproved

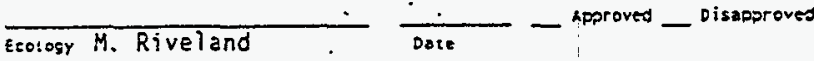


Description/Justification of Change (Continued)

The REC complex of the 324 Building is designed to handle high activity radioactive wastes and materials in a research setting, with remote handling capabilities, and with appropriate shielding and unique space considerations.

A 324 hot cell restoration project (the B-Cell Cleanout Project (BCCP)) has been initiated in an effort to clean out and stabilize high activity, dispersible $M H$ that have accumulated in the REC B-cell. Work under The BCCP will also result in the removal of $M$, inactive research equipment, and other materials housed in the B-cell. Containerized $M W$ are currently being stored in the REC (primarily in B-cell). One container of oil and absorbent from a $1994 \mathrm{~B}-\mathrm{celll}$ shielded viewing window leak is stored in the D-cell. Containerized storage of high activity $\mathrm{MW}$ in the B-cell will continue until a technically sound pathway for storage elsewhere, and/or treatment and disposal is developed.

Containerized MW storage in the REC may include waste transferred from the HLV tanks as a result of implementation of the preferred optjon identified via milestone M-89-01A. The (M-89-01A) report will identify the preferred option, provide planning/execution details and allow implementation of actions necessary to ensure safe handling and removal of liquid MW in the HLV tanks. Treatment and storage of HLV tank wastes in the REC will require development of an acceptable technical process and compliance with regulatory. requirements.

High activity Jiquid $M W$ is being stored in the 324 Building HLV tanks (e.g., TK-104, -105, -107). These wastes were originally utilized as radioactive feed materials for research and development projects conducted in the REC.

Initial assessment by USDOE of the waste management options for these materials has determined that they present difficult management challenges in that (at present) no definitive workplan for transportation, treatinent and disposal, and/or long term permitted storage exists. Because of the location of the 324 building with respect to the columbia River and the Tri-cities, the high activity of the wastes, and the dispersibility of the waste in the B-cell, these wastes pose a significant environmental, worker safety, and public health risk. These milestones have be:n proposed to minimize these risks in the near term, to achieve compliant management of the wastes, and to ensure long term protection of human health and the environment.

The following. Milestones set the Schedule for key actions necessary to achieve compliance and complete closure of non-permitted mixed wiste units in the 324 Building Radiochemical Engineering Cell (B-cell and D-cell), and Higli Level Vault:

H-89-00 Complete Closure of Non-Permitted Mixed Kaste Units in the 324 TBE* Building REC B-cell, REC D-cell, and high Level Vault.

*A date will be estabiished for this Major Milestone immediately following Ecology approval of the REC/HLY closure plan (see $1-20-55$ ).

K-89-01 Complete removal of 324 Building HLY tank $M H$ (e.g., TK-104, TK-105, TK-107) with the exception of residues which may remain following flushing and oraining :0 the extent possible.

M-89-01A USDOE will submit to Ecology a report identifying the preferred option for management of liquid $1 \mathrm{H}$ in the HLV tanks.

$10 / 31 / 96$

$3 / 31 / 95$ 
Deseription/Justiflestion of Change (Cantinued)

M-89-02 Complete removal of 324 Building REC B-cell WH and equipment.

$5 / 31 / 99$

Actions under this milestone include containment and removal of all B cell dispersible materials, excess equipment and debris. Containerized $t h$ will be managed in compliance with chapter 173.303 KAC, thereby reducing risks to human health and the environment. Any remaining residues following removal actions will be managed through the final closure process. USDOEs' 324 building REC $B$ cell clean-out project (BCCP) will be used as a guide for containerizing dispersible $M H$ and removing unnecessary equipment and materiais from B-cell.

1 -89-03 Achieve compliance with interim status facility standards at non-permitted 324 building $\mathrm{KH}$ units.

Because of high radiation fields associated with $M U$ stored in the REC and $H L V$ tanks, alternative compliance measures for some interim status requirements are expected. In these instances USDOE will propose alternative measures for Ecology approval no later than March 31, 1995.

N-89-04 . Submit to Ecology a report identifying Mh management alternatives and USDOE's proposal for achieving clean closure of the 324 Building REC B-cell, D-cell and HLV. This report will aid development of the 324 Closure Plan required by milestone $1-20-55$.

The proposal will outline a feasible and cost effective program to achieve clean closure of the non-permitted storage units and compliant management of the $M H$ currently stored in them.

M-20-55 Submit closure pian for Non-Permitted Mixed Kaste Units located in the 324 Building REC B-cell, REC D-cell and HLV. 
This page intentionally left blank. 
DOE/RL-96-73, Rev. 0 $05 / 31 / 97$

\section{APPENDIX 2A}

\section{BUILDING ENGINEERING DRAWINGS}



HIGH LEVEL VAULT AND CELL AREA BLDG EL AT SECT A-A 0 HIGH LEVEL VAULT AND CELL AIREA BLDG EL AT SECT A-A 0 FACILITY DRAWINGS CELL AREA BLDG EL AT SECT C-C 


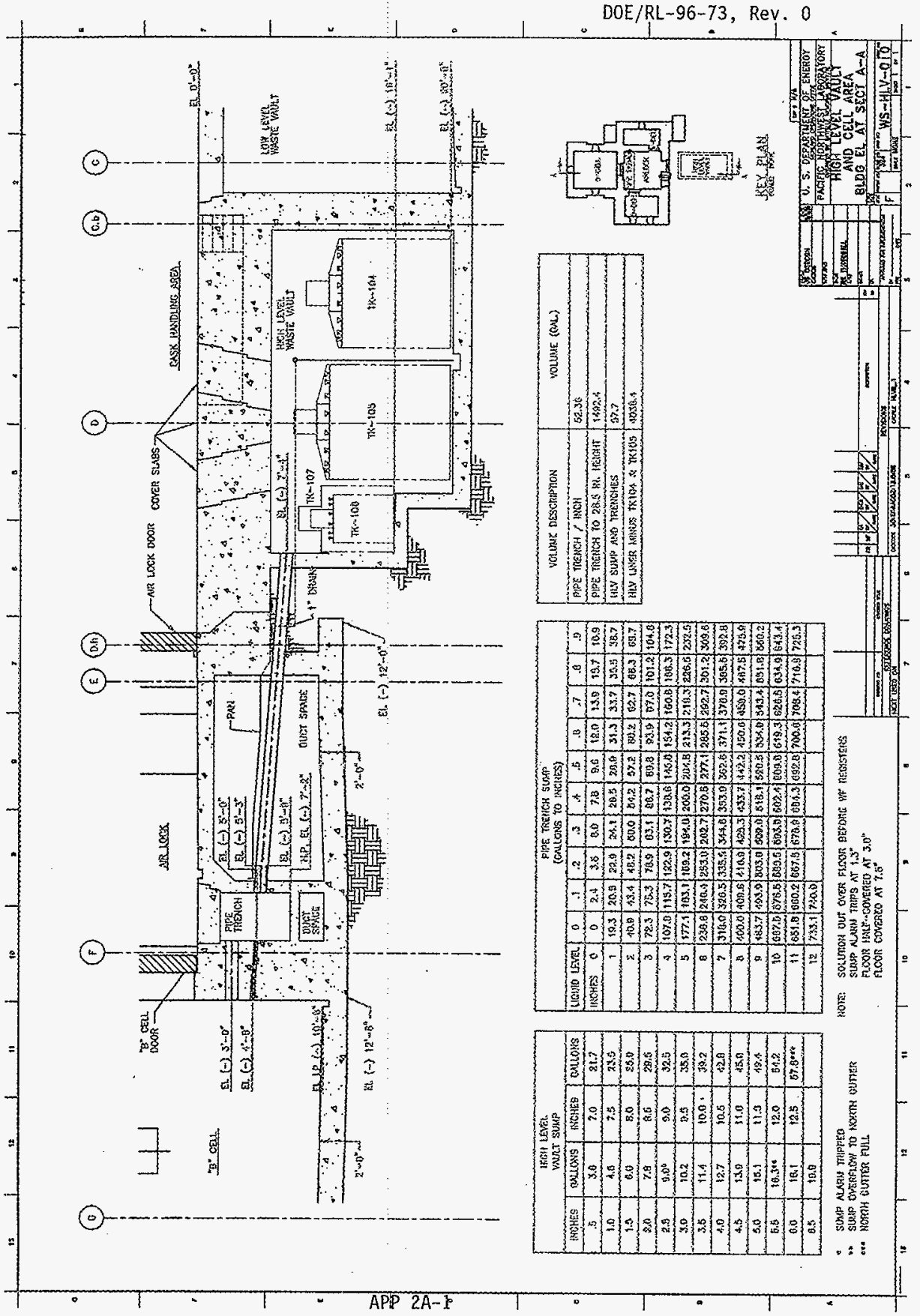




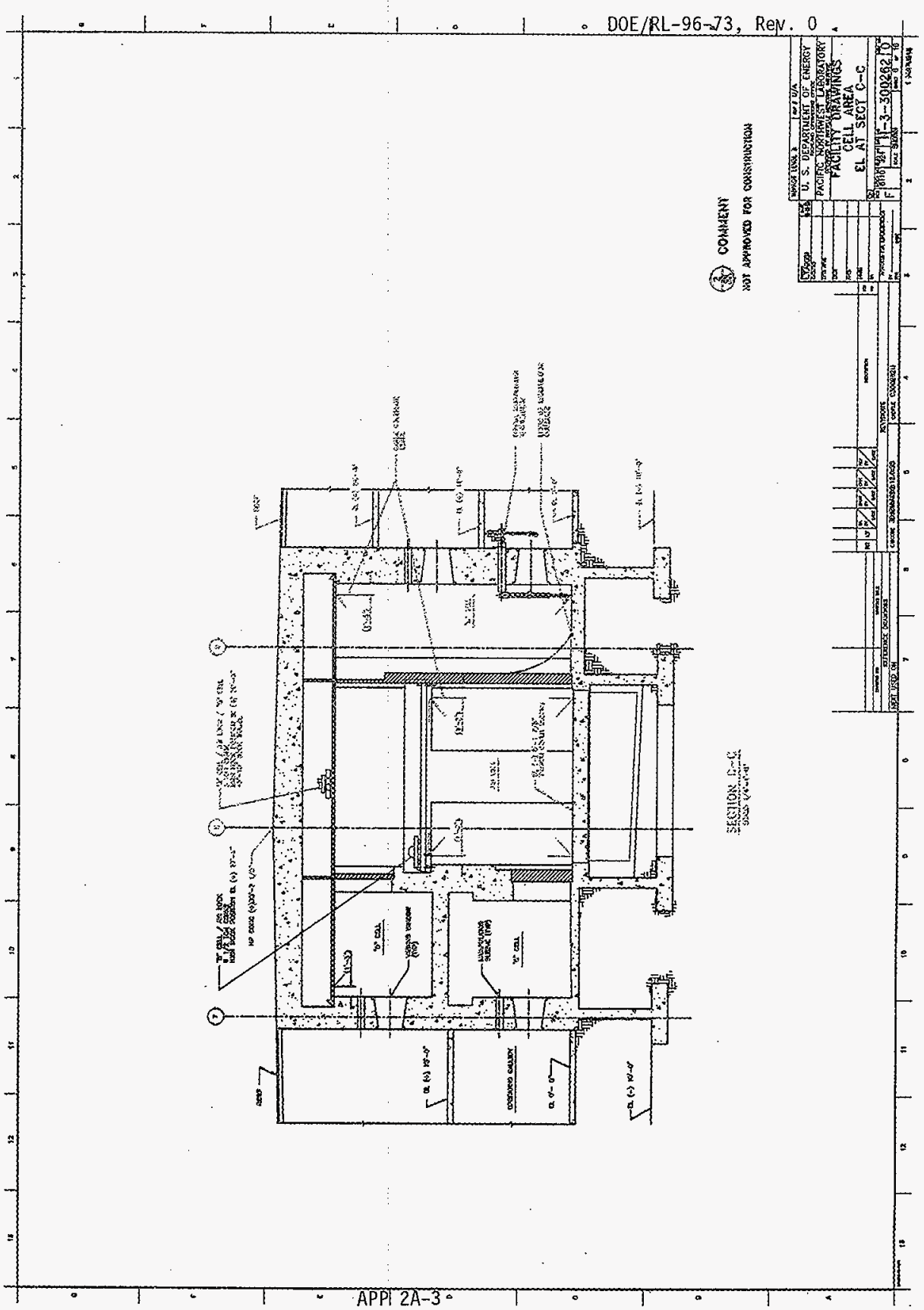


OFFSITE

MSIN

2

Washington State Department of Ecology

S. Alexander

B5-18

J. Wallace

B5-18

1

J. R. Witkinson

Confederated Tribes of the Umatilla Indian Reservation

P. 0. Box 638 :

Pendieton, Oregon 97801

1

D. Powaukee

Nez Perce Tribe

P. 0. Box 305

Lapwai, Idaho : 80540

1

R. Jim, Manager

Environmental :Restoration/ Waste Management Program

Confederated Tribes and Bands of the Yakama Nation

P. 0. Box 151

Toppenish, Washington 98948

\section{ONSITE}

MSIN

6

U.S. Department of Energy, Richland Operations office

R. X. Gonzaiez

R3-79

D. C. Langstaff

R3-79

E. M. Mattion :

A5- 15

L. D. Romine

R3-79

Reading Room

$\mathrm{H} 2-53$

5

B\&W Hanford Company

K. A. Hadley

R3-56

G. D. Hendricks

R3-56

D. 0 . Jenkins

L1-01

G. J. Lebaron

S6-19

P. J. Weaver

L1-02

Fluor Daniel Hanford. Inc.

H. Z. Dokuzoguz

$\mathrm{N} 1-26$

F. A. Ruck

H6-22 
DOE/RL-96-73, Rev. 0 $05 / 31 / 97$

4

1

7

\section{DISTRIBUTION (cont)}

Lockheed Martin Services, Inc.

Central Files

DPC

EDMC (2)

A3-88

A3-94

H6-08

Pacific Northwest National Laboratory

Hanford Technical Library

Rust Federal Services of Hanford Inc.

R. C. Bowman

RCRA file

H6-24

$\mathrm{H} 6-24$

H6-24 